\title{
The Boy Who Lived: How Canadian Newspapers Used the Image of the Death of Aylan Kurdi
}

\author{
by
}

Mira Knox

A thesis submitted to the Faculty of Graduate and Postdoctoral Affairs in partial fulfillment of the requirements for the degree of

Master of Arts

in

Sociology

Carleton University

Ottawa, Ontario

(C) 2017, Mira Knox 


\begin{abstract}
On September $2^{\text {nd }} 2015$, a photograph was taken of the lifeless body of three-year-old Aylan Kurdi. In the following days, Aylan's image was widely internationally circulated. In Canadian newspapers this image appeared alongside articles discussing the image as objective proof of the unavoidably violent and horrific conditions suffered by refugees who depart fleeing the War in Syria and the supposedly glorious arrival conditions awaiting refugees in Canada. Aylan's image extends his presence and was used by Canadian newspapers to perpetuate western imperialist ideations about the role of the west in the War in Syria. These interpretations of the departure and arrival conditions of Syrian refugees eclipse all other information regarding the departure of refugees from Syria or the arrival of refugees in Canada and this thesis first committed to the critical scrutiny of these unquestioned interpretations and second to the presentation of alternative interpretations of the War in Syria.
\end{abstract}




\section{Acknowledgements}

I would first like to thank my thesis advisor, Professor Nahla Abdo for guiding and supporting me over the past two years. You have set an example of excellence as a researcher and scholar. I could not possibly have completed this project without your expertise and guidance. Your tireless dedication to my development as a researcher and to the development of this project was incomparable. It was a pleasure working with you.

I would also like to thank my thesis committee members for all of their guidance through this process; Professor Amina Mire and Professor Peter Gose your discussion, ideas, and feedback have been absolutely invaluable and have greatly strengthened my project. Professor Mire, our discussion in your office one sunny afternoon on Orientalism and the television show "The Jewel in the Crown" was one of the most enjoyable academic experiences of my career thus far. Professor Gose, your discussion of the White Helmets and trustworthy news sources informed a large piece of my writing, and I remain indebted to you for that.

I would also like to thank my external examiner Dr. Shupak for taking time out from his busy schedule to participate in my Masters Thesis defence. Your thoughtful questions and deep consideration of my research was greatly appreciated.

I must also take a moment to thank Professor Carol Payne whose suggestions and instruction on various sources and information I might need for this project were crucial to the successful completion of this project.

Finally, I would like to thank my family and friends, who all believed I could do this even when I didn't. I am grateful to all of you for the million ways both big and small though which you continuously demonstrated your support and affection. Thank you all. 


\section{Table of Contents}

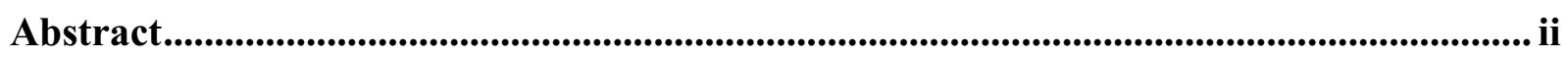

Acknowledgements ................................................................................................................... iii

Table of Contents ........................................................................................................................................ iv

List of Figures...................................................................................................................................... vi

1 Chapter: Introduction ........................................................................................................... 1

1.1 Working Argument and Research Questions …………………….......................... 1

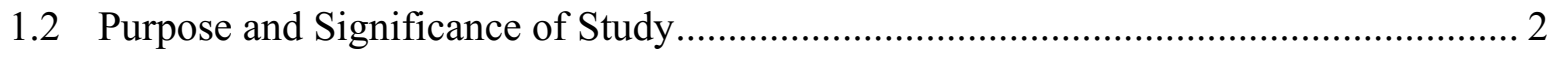

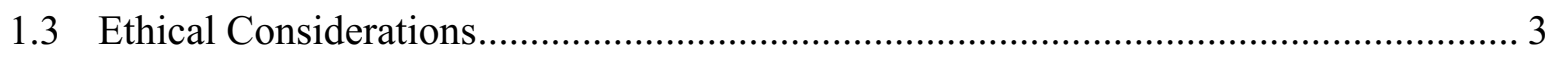

2 Chapter: Review of the Literature .......................................................................................... 8

2.1 Conceptual and Theoretical Framework ………..................................................... 8

3 Chapter: Historical Background ............................................................................................ 14

3.1 The War in Syria: An Introduction ................................................................. 14

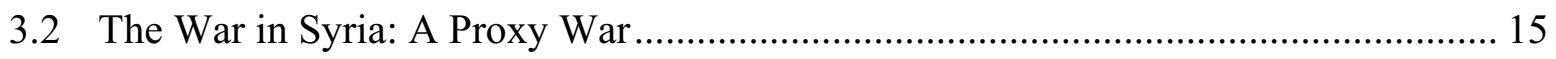

3.3 The War in Syria: Major Participants ................................................................. 17

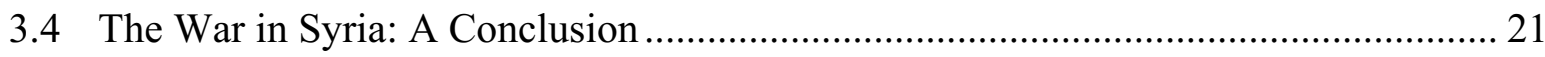

4 Chapter: Methodology ............................................................................................................. 22

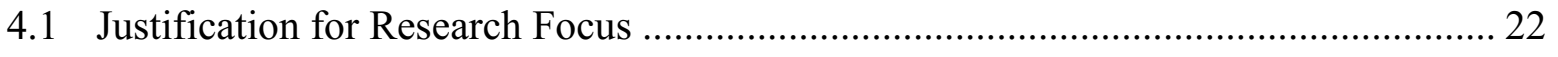

4.2 Research Design Elements: Photograph Analysis ...................................................... 23

4.3 Research Design Elements: Discourse Analysis ........................................................ 26

5 Chapter: Research Findings ................................................................................................. 29

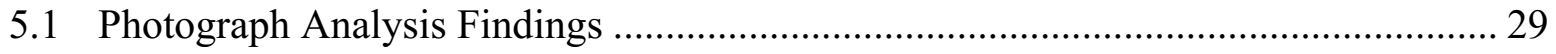

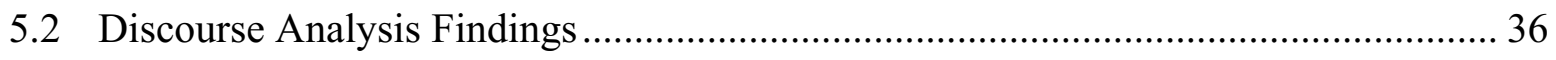


5.3 Arrival of Syrian Refugees in Canada...................................................................... 41

5.3.1 Broken Refugee Acceptance Process ..................................................................... 41

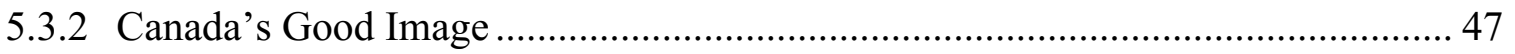

5.3.3 Federal Election Game ................................................................................. 50

5.3.4 Canada Can Profit from Refugees....................................................................... 54

5.3.5 Refugees are Unwanted.................................................................................. 56

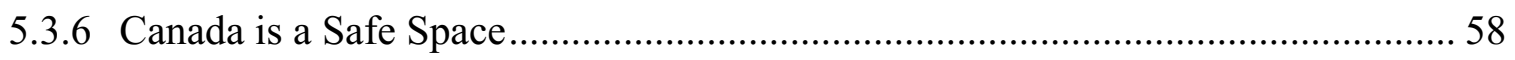

5.4 Departure of Syrian Refugees from Syria ………………………………………….... 60

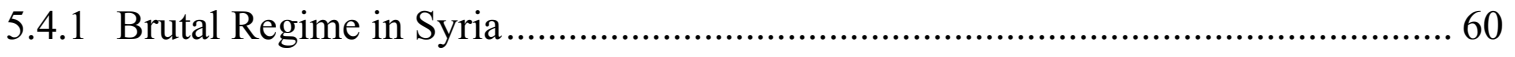

6 Chapter: Further Discussion................................................................................................... 66

7 Chapter: Conclusions, Limitations and Suggestions for Future Research.................... 75

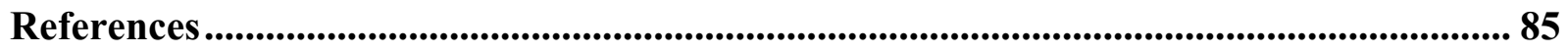




\section{List of Figures}

Figure 1 Actual photo versus line drawing ...........................................

Figure 2 Aylan Kurdi in Bodrum, Turkey with his face-down and feet near the viewer..........30

Figure 3 Aylan Kurdi in Bodrum, Turkey with his face-down and face near the viewer.........32

Figure 3a Aylan Kurdi in Bodrum, Turkey with his face-down and face near the viewer..........33

Figure 4 Aylan Kurdi in Bodrum, Turkey being carried................................. 34

Figure 4a Aylan Kurdi in Bodrum, Turkey being carried with diagonal lines..................35

Figure 5a NVivo created word-tree depicting some word associations with "arrive"............38

Figure 5b NVivo created word-tree depicting some word associations with "leave".............38

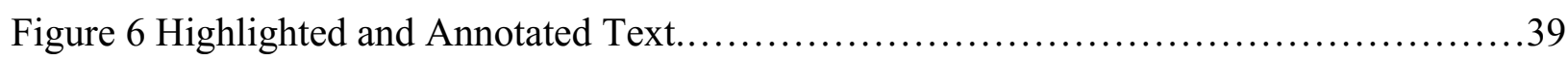

Figure 7 Diagram of Discourse Analysis Coding Process..................................39

Figure 8 Map of Aylan Kurdi's crossing ...........................................46

Figure 9 Photograph of Chinese artist Ai Weiwei..................................... 83 


\section{List of Tables}

Table 1 Summary of Results and Notable Findings..................................77-78 


\section{Chapter: Introduction}

\subsection{Working Argument and Research Questions}

My thesis research focuses on the photograph of the drowned Syrian refugee, Aylan Kurdi on the beach in Bodrum, Turkey. This photograph, taken by Turkish photographer Nilufer Demir, was widely internationally circulated in the first week of September 2015 following Aylan's death on September $2^{\text {nd }} 2015$. Arguably, this photograph has come to exist as symbolic of the War in Syria and has been co-opted by the Canadian news media (among other western media outlets) to advance a particular narrative that aligns with and justifies their western imperialist political and economic agendas. Throughout my research I question how certain images of the "other" in crisis get used to advance particular response agendas.

In this thesis I argue that the response agendas advanced by the Canadian news media relate in particular to claims about refugee departure from their countries of origin or claims about refugee arrival in their destination countries. Aylan's body located on the beach is both arriving and departing. He is washing up and washing away. He is flotsam or jetsam; waste on a beach where he is unwanted but present. Using his image, the Canadian news media makes certain claims about the departure of refugees from Syria as well as certain claims about the arrival of refugees in Canada. Aylan's photograph facilitates these claims in two ways. First Aylan's photograph is assumed to constitute proof of an objectively true reality and second, Aylan's photograph confirms previously held beliefs about reality forcing a comparison of all other interpretations of reality to that photograph. Sontag (1977) argues that photographs are evidence and as such substantiate and prove what we hear about; "passing for incontrovertible proof that a given thing happened" (p. 5). Despite the ability of photographers and photographs to substantially alter and selectively interpret their content; photographs enjoy a "more innocent, and therefore more accurate, relation to visible reality than do other mimetic objects" and 
embody a strong "presumption of veracity" (Sontag, 1977, p. 6). Sontag (1977) further argues that photographs are not scrutinized for their proximity to reality; but that reality is scrutinized for its proximity to photographs. Photographs can furnish evidence for what we already believe, making all other interpretations seem lackluster or less real in comparison. This means that photographs may not tell the whole truth or even part of the truth, but they are still regarded as providing irrefutable evidence for truth claims (Sontag 1977).

\subsection{Purpose and Significance of Study}

As discussed above, photographs are used as evidence for beliefs and as justification for actions, regardless of their actual relationship to reality. My argument that the Canadian news media has used the photograph of Aylan Kurdi to make certain imperialist claims on the nature of the departure of Syrian refugees from Syria and their arrival in Canada has particular implications for my research. While I understand that my coding process around arrival and departure may place excessive demands on my data, and that the data may not be clearly divided into those categories, I maintain that there is a theoretical importance to my choice to organize and divide the coding of the data around departure and arrival. This choice is theoretically important due to the particulars of Aylan's case. Aylan is essentially in limbo between departing his country of origin, Syria, and arriving in his intended destination country of Canada. However, Aylan did arrive on a beach near Bodrum, Turkey and his widely circulated image is one that freezes him in this moment of arrival. In this sense Aylan has both departed and arrived as a refugee. Stein (1980) states in his discussion of the Kunz' kinetic model of the refugee experience; departure from one's homeland marks a refugee, as does a refugee's arrival in the new land. Stein's extensive and unprecedented examination of the totality of the refugee experience endorses the seminal nature of his work. His inclusion of pre-departure and postarrival conditions in the refugee experience supports my choice to code around both arrival and 
departure. Questions about what drove Aylan's family to depart Syria by boat and where Aylan's family were going became significant to the western media (specifically Canadian news media) after his death. Aylan's case was co-opted by the western and Canadian news media to highlight the dangerous nature of both the departure and arrival processes for Syrian refugees and to present the west as a savior and haven for refugees while simultaneously demonizing Syria as a nation that forced a little boy to his death. The photograph allowed stories to be told about the conditions of arrival and departure of Syrian refuges by the western, and Canadian, news media. As mentioned above, this co-option reduces the complexity of the refugee experience and obscures the role played by the west in the creation and maintenance of the War in Syria, and the eventual displacement of millions of Syrians.

\subsection{Ethical Considerations}

Before beginning a discussion of the ethical considerations of my research process, I would like to make a distinction between what Marilys Guillemin and Lynn Gillam (2004) call "procedural ethics" and "ethics in practice" (p. 263). Procedural ethics are defined as ethics as approved through a formal ethics board approval process, while ethics in practice are defined as the ethical issues that come directly out of the practice of interpretive qualitative research to which my research ascribes (Guillemin \& Gillam, 2004, p. 263). Since this project will not require formal ethics board approval, due to its archival data sources and lack of human research subject involvement, my ethical dilemmas will strictly arise from my deployment of ethics in practice.

The main ethical dilemma that I face is how my work will contribute to the spread of the image of Aylan Kurdi. In conducting my research with the various iterations of the photograph I will be using it for my own endsI will be talking about it, reproducing its content, and circulating it. The image of Aylan Kurdi, and by extension Aylan himself, will be the subject of my 
research. Aylan will unavoidably be used as a tool in my research process, which directly contravenes my own and Guillemin and Gillam's (2004) commitment to ethics in practice.

To mitigate the use of Aylan's photograph, and by extension Aylan himself, as a tool and to attempt to reassert my commitment to ethics in practice, I have developed two strategies. The first strategy is to consider Aylan's photograph, and by extension Aylan himself, as a participant in my research process. I will try to imagine Aylan as actively participating in my research. I will try to continually question and examine the privilege and power held by myself as a researcher when I, like Beuthin (2014), attempt to create equality and a genuine relationship with my participant. I will perform throughout the research process a series of check-ins with Aylan as I imagine him, trying to obtain Lahman et al.'s (2015) 'iterative consent', which is a process of ongoing consent throughout the study; and of 'process responsiveness', which is a continuously reflexive stance whereby the researcher monitors participant comfort levels with the research (p. 451). These check-ins will hopefully allow me to locate myself in the process and to challenge my assumptions about my participant, enabling me to find a respectful place of negotiation with Aylan's life and body.

I realize that the tactic of check-ins with an 'imagined participant' could be construed simply as "reflexivity as recognition of self" which is the first type of undesirable "comfortable reflexivity" outlined by Pillow (2005, p. $182 \& 187)$. Since I will be really only in dialogue with my own imagination, I might only be reflexive insofar as I can reflect on and recognizing myself in my research. In discussing the dangers of "reflexivity as recognition of self", Pillow cautions against imagining reflexivity solely as a process of self-recognition, arguing that this promotes the hearing of only some reflexive tales and simplifies the complex negotiations and coconstitutions between the researcher and the researched (2005, p. 187). Pillow advocates for 
"reflexivities of discomfort" when doing qualitative research which are messy and disruptive, and leave us with "the uncomfortable realities of doing engaged qualitative research" (2005, p. 193). I worry that my imagined dialogue with Aylan is simply a use of Pillow's (2005) "reflexivity as recognition of self" and is insufficient to properly articulate the complexities and messy tangles of the qualitative research I want to conduct with Aylan.

To supplement this first strategy, I have a second strategy that will hopefully allow me to reassert my commitment to ethics in practice. In order to reduce the use of Aylan Kurdi's photograph, and by extension Aylan himself as a tool in my research, I have decided not to reproduce any photographs of Aylan Kurdi. Instead, I will construct line drawings of the photograph and I will produce those line drawings only when absolutely necessary for a particular piece of image analysis. This feels like a positive commitment to my participant as a human as well as a conscious commitment to reducing the use of Aylan's body and life. For an example of this style of drawing, please see Figure 1 below.

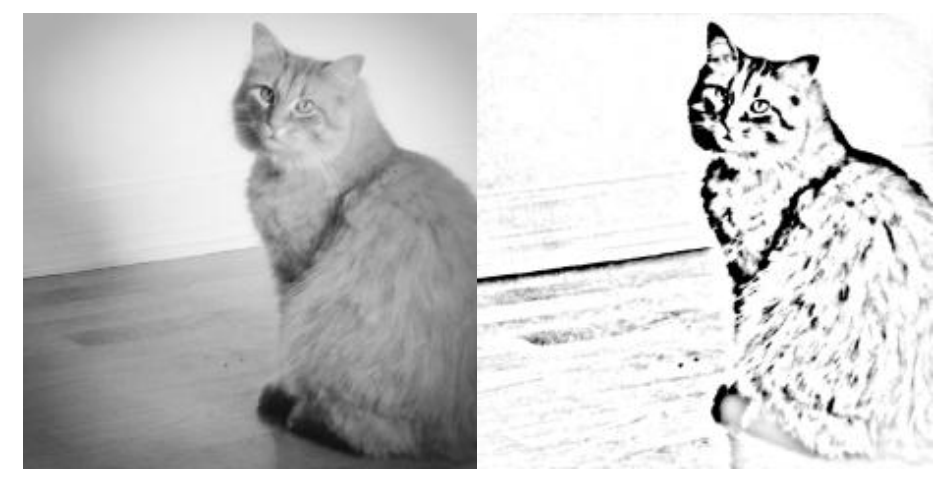

Figure 1: Actual photo versus line drawing.

Sentilles (2008) notes that many media agents have argued for the release of violent photographs (such as those taken in Abu Ghraib prison), "because they assumed the photographs would elicit an emotional response that would lead to political action against the violence depicted in the photographs" (p. 522). While this has been the effect, Sentilles states that the 
dissemination of these photographs has also given rise to many other responses which "expose as false the assumption many photography theorists make that viewing representations of violence necessarily leads to empathy, and that empathy necessarily leads to beneficent action on behalf of those pictured" (2008, p. 522). In other words, empathy is one of many possible responses to violent and disturbing images, and that even when empathy is produced; it does not always have beneficial consequences for those depicted. I have chosen not to reproduce the photograph of Aylan Kurdi because I am concerned with the consequences that some empathetic and nonempathetic responses have for Aylan and other Syrian refugees.

Giroux's work (2011) builds on Sontag's assessment of photographs as partial truth tellers and argues that; "images of human suffering are increasingly abstracted from social and political contexts and the conditions that make such suffering possible" (p. 4). The expeditious distribution of Aylan's photograph has accelerated a process of mis- and dis-information as it has become further isolated and removed from its context. I have chosen not to reproduce and distribute the photograph of Aylan to mitigate the photograph's contribution to the mis- and disinformation around the circumstances of his death, about Syrian refugees and about the War in Syria.

However, all of this talk about "saving" Aylan from being used by my research and trying to "save" his photograph from being increasingly circulated through my research is revoltingly reminiscent of what feminists Lila Abu-Lughod (2002), Miriam Cooke (2002) and Sonali Kolhatkar (2002) have discussed. While their focus was on the U.S. War on Terror's use of the "plight" of the Muslim woman to galvanize western intervention and violence in the Middle East; the work of these authors also applies to Aylan's case. These authors all describe the concept of "saving" the racialized Muslim woman as not only unnecessary but also an 
imperialist and racist desire of the west. These feminists understand the role played by western patriarchy and even western feminist discourse in casting Afghan men as misogynistic religious extremists and Afghan women as helpless victims. In their work, they seek to admonish the imperialist practices of white feminists who attempt to speak for the "other" woman and envelop her into the western feminist discourse. My attempt to mitigate the effects of my research on Aylan and by extension on Syrian refugees could be read as a similar imperialist move. Although I stand by my commitment not to reproduce his photograph in full, and by my commitment to iterative consent and ongoing reflexive research practices, I cannot help but use Aylan's photograph and by extension Aylan himself as a tool in my research. Therefore in addition to these choices, I will also endeavor to conduct a rigorous and critical analysis of Aylan's photograph and of the Canadian news media's role in disseminating information about the War in Syria. My research must have an implication that challenges orientalism, imperialism and racism. This is the major implication of my research. Although Aylan is dead, my presentation of how his life and body were used to spread disinformation about the war in his country of Syria is what matters. As Abdo (2014) asserts: "the one significant question in research is not who can speak for or represent a group, rather how that group, especially a marginalized one, is being presented" (p. 10). Abdo's (2014) call for considerations of the insider/outsider perspective on research is particularly crucial in my own research as I am undeniably an outsider to Aylan's situation; and therefore must redouble my efforts to present a thoroughly rigorous and critical analysis. 


\section{Chapter: Review of the Literature}

\subsection{Conceptual and Theoretical Framework}

My research draws from two of my theoretical allies: Sontag (1977) and Said (1978). Sontag's work in her essay "In Plato's Cave" asserts that photographs first change what we want to look at, then alter what we have a right to look at and finally give people the sense that they can see the whole world by holding its images in their heads (Sontag, 1977, p.3). Collections of photographs according to Sontag, become collections of the world and through these images the world is objectified, collected and stored. Photographs place the photographer and the object in a special relationship: photographs appear to contain more knowledge about the object, which grants the photographer uniquely, detailed knowledge about what they are photographing. Photographs, as Sontag states, are unlike written statements or descriptions of the world and indeed seem to be more like "pieces of the world" or like "miniatures of reality" that people can acquire (Sontag, 1977, p. 3).

In her essay "The Image World", Sontag focused on the ubiquity of the image in the 'modern' world, wherein images are readily and hungrily consumed and have the power to "determine our demands upon reality and are themselves coveted substitutes for firsthand experience" (Sontag, 1977, p. 153). Sontag states that an element of a "modern" state is the production and consumption of an enormous multitude of images, which have come to be one of the only modes of understanding and apprehending this "modern" reality. Sontag again states in this essay that this understanding through images stems from photographs being synonymous with the acquisition of knowledge of objects and with control over those objects. Sontag states that when an object is photographed it becomes "part of a system of information, fitted into schemes of classification and storage which range from the crudely chronological order of snapshot sequences pasted in family albums to the dogged accumulations and meticulous filing 
needed for photography's uses in...astronomy" (Sontag, 1977, p. 156). Indeed, it is to this example of astronomy to which Sontag next turns when she describes early experiments in photography at Cambridge where astronomers were attempting to photograph the star Vega. Sontag states that these astronomers were attempting to photograph light that left the celestial sphere of the star twenty years prior to the experiment. This light was therefore entirely uncontrolled by the photographer, but appeared under his control once captured in the image. As photographic technology has progressed, Sontag asserts that the sense in which a photograph gives control over an object has rapidly increased. The near instantaneous speed with which photographs are produced by photographer and distributed to consumer through various media outlets has highlighted the control and knowledge the photographer has on their subject.

Bartlett, a freelance journalist has reported extensively on the western media's fabrication of the War in Syria. Like Sontag, Bartlett discusses instances where she argues that the western media has manipulated and controlled the objects of its focus. For example, Bartlett discusses the "White Helmets", officially known as the Syria Civil Defense (SCD). The "White Helmets" are an anti-Bashar al Assad political group supposedly operating as rescue personnel in eastern Aleppo. The "White Helmets" are financed, trained and directed by the government of the United States and funded by the UK, Japan and USAID (Bartlett 2016, Blumenthal 2016). Blumenthal, editor of AlterNet, has argued that while the "White Helmets" may save some civilian lives, they exist largely to promote and lobby for “.... U U.S. military campaign that will almost inevitably result in the collapse of Syria's government" (Blumenthal, 2016). In western media the humanitarian dimension of the "White Helmets" is emphasized, while their political machinations are obscured. As Bartlett (2016) notes, the "White Helmets" maintain an intense and active media presence and are the subject of a recent Netflix documentary. Photographs of 
"White Helmets" working in war-torn areas and conflict zones in Syria have been extensively produced and reproduced to advance a particular message about the necessity of intervention in Syria. Despite the "White Helmets" apparently massive activity, Bartlett (2016) states that none of the internally displaced persons, doctors or citizens she interviewed in Aleppo had heard of the "White Helmets". This discrepancy between what is actually observed on the ground in Syria and what is apparently the photographic "truth" highlights the control of the western media over the narrative of the War in Syria. In the case of the "White Helmets" it has been noted that some images of the group have actually been fabricated and staged (Blumenthal, 2016). The role of the west in the fabrication of news items about the War in Syria will be continually examined throughout this paper.

The image of Aylan Kurdi, hungrily consumed, makes certain western demands and agendas possible and warranted. His image has become a substitute for firsthand experience, a trace or something "stenciled off the real, like a footprint or a death mask" that allows for the fabrication of the image and reality of the Syrian refugee by the west (Sontag, 1977, p. 154). Photographs of Aylan Kurdi have appropriated his body (Sontag, 1977) and have granted a power over his life to journalists who use his photograph. To photograph a person, is an act of violent appropriation of that person as an object (Sontag, 1977). The widespread circulation of Aylan's photograph by the western media has negatively objectified Syrian refugees. This has functioned in a similar way to the reductionist and racist representations of Islam in the west that are examined by Abu-Lughod (2006), whose work also draws from Said (1978). Abu-Lughod (2006) has done extensive work on Islamism in the media, and applies the concept of orientalism to an examination of the western media's depictions of Islam and Arabs. The centralization of Aylan's photograph has allowed the nonspecific and ahistorical western reading of Syrian 
refugees and thus a "simplistic oppositional discourse has become hegemonic" (Abu-Lughod, 2006, p. 5). The camera shoots an object and is a "sublimated gun" whereby people become fixed in their instantaneous and soft death in their photographs (Sontag, 1977,p. 14). Photographs imply that we can know something by seeing its image but do not allow changes to that particular viewpoint and therefore prevent any actual understanding (Sontag, 1977). The western media has claimed to "know" the image of Aylan, and thus to know the situation of Syrian refugees. The circulation of Aylan's photograph has sustained a particular racist and historydenying interpretation of Syria and Syrian refugees and is unable to explain why or how something has happened.

To further examine the use of Aylan's body and life, I turn to Said's concept of orientalism. Orientalism is a process whereby the west positions itself as superior to its imagined understanding of the Orient (Said, 1978, p. 7). Said's work (1978) on how sovereign and unchallenged western powers solidified notions of the Oriental "other" "first according to general ideas about who or what was an Oriental, [and] then according to a detailed logic governed not simply by empirical reality but by a battery of desires, repressions, investments and projections" can be applied to how the western media depicts the Middle East (p. 8). As noted by Abdo (2014), Said's work (1978) remains pertinent today, as an understanding of contemporary war in the Middle East requires a consideration of the historical imperialist and colonial contexts that have shaped the development of these wars. Additionally, Abdo (2014) notes that not only are new forms of imperialism accompanied by a "demonizing and dehumanizing [of] the invaded people and colonized victims" but that these blatant forms of racism are also masked by a sophisticated epistemological costume. This epistemology allows the west to frame conflict and 
its methods of dealing with it as spreading "democracy" and fighting "terrorism" while only thinly veiling its desire to support its own geo-political and economic interests.

White westerners are located unquestioningly as the viewers and consumers of the photograph of Aylan Kurdi. His photograph was used by the western media to garner support and justify western military intervention in Syria. Anderson, in his book The Dirty War on Syria (2016) discusses western media "embededness" in Middle Eastern conflict and western media "watchdogs" who call for western intervention in the War in Syria. Anderson (2016) states that the close link between western media and western military intervention has served to humanize western intervention efforts and served to caricature the enemy. Anderson (2016) uses the example of the 2003 invasion of Iraq by the United States to discuss how journalists deployed with the military were tasked with depicting the successes of the invaders and to underline the necessity of their involvement by demonstrating the barbaric nature of the enemy. Anderson (2016) notes that it was only much later on in the war were images shared of the invaders that fell outside of this narrow and positive slice. In Syria, Anderson (2016) argues that many seemingly "liberal" NGOs have contributed to disinformation about Syria. He states that the director Kenneth Roth of the United States based Human Rights Watch has "shown an obsession with President Bashar al Assad" and has used various social media platforms to continuously allege links between Syrian President Bashar al Assad and various atrocities committed throughout the course of the War in Syria (Anderson, 2016, p. 55). Anderson (2016) also reports that another NGO Amnesty International, which has closely linked itself with the United States, has also committed itself to a program of disinformation by claiming that the Syrian Army has caused a "“collateral damage' rate of almost 100 civilian casualties for every one 'fighter' killed" 
(p. 65). This claim is unsupported by evidence that has not been "tainted by partisan sources and contradicted by other information" (Anderson, 2016, p. 56).

Aylan Kurdi's photograph, taken by Turkish national Nilüfer Demir, has been co-opted by the western media to advance the need for western military and humanitarian intervention. When deployed by the western media, this photograph simultaneously highlights the humanity of the West and its allied powers and also denigrates the atrocities committed by the "enemy" in Syria. A discussion of the appropriation and consumption of Aylan's body and life by the western media and the resultant "othering" of Aylan and by extension "other" Syrian refugees which culminates in the supposed western "right to intervene" in Syria; will be the crux of my contribution in this thesis. This contribution will also hopefully encompass a wider critique of the western media's dissemination of knowledge about Syria and the Middle East as a whole. To that end, the following section will provide a historical background on the War in Syria and the role that western countries have played and continue to play in shaping the conflict and response to the conflict. 


\section{Chapter: Historical Background}

\subsection{The War in Syria: An Introduction}

As discussed above, Aylan's photograph has been used as evidence to furnish certain knowledge claims about Syria and Syrian refugees made by the Canadian media. Although a thorough examination of these knowledge claims will be conducted in the data analysis section of this thesis, a comparison is required to determine which knowledge claims are valid and which are orientalist musings. It will therefore be useful to provide a brief historical background of the War in Syria and to discuss how this conflict came to produce a massive movement of refugees. This historical background will provide a brief summary of the genesis of the War in Syria, an explanation of two incidents that affirm its proxy-war nature and a discussion of the major participants in the conflict.

The War in Syria arguably began in 2011, following nationwide protests. Hersh (2013) argues that these protests stemmed from similar protests and demonstrations across the Middle East in what has come to be known as the "Arab Spring" (p.2). It is important to note that while many tens of thousands marched against the Syrian government, millions also marched in support of this government. Anderson (2016) purports that both before and after these protests the Syrian President Bashar al-Assad and his government held the support and loyalty of most of the Syrian population; an estimated 70\% (p. 8). The War in Syria began as a civil war following these protests, which can be defined as a violent conflict within the confines of a state in which one side of the conflict is the state itself (Hironaka, 2005). However, the War in Syria soon became an international proxy war between the Syrian Army, various terrorist groups, and other autonomous regions. Western countries, especially the United States, have a long history and experience in "dirty, covert wars, fought through proxies" and are responsible for escalating the War in Syria (Anderson, 2016, p. 5). This type of proxy warfare by the United States and its 
allies is "part of a strategy to delegitimize the Syrian Government, with the aim of fomenting 'regime change"' (Anderson, 2016, p. 15). As Giraldi states, in the United States, there is significant support for an Assad regime-change due to the belief that a weakened Syria, will present no threat to the interests of the United States and its allies (2011).

A deeper discussion of how and why the War in Syria has become known as a Civil War, rather than a proxy-war, will be conducted in a later chapter of this thesis. During the past five years of the conflict five major groups coalesced; the Syrian Army; the al-Qaeda affiliated Jabhat Fatah al Sham (formerly known as the al-Nusra front); the Saudi-backed 'Islamic Front' a merger of the former Free Syrian Army (FSA) groups; the Islamic State of Iraq and the Levant (ISIL), also known as the Islamic State of Iraq and al-Sham (ISIS); and much later Rojava, also known as Western Kurdistan which is an autonomous region originating from three selfgoverning cantons in northern Syria (Anderson 2016, Bassam \& Osborn 2015, Hersh 2014, Mahmood \& Chulov 2015). While the lines between and among these groups have shifted, a deeper discussion of the role of terrorist groups in the War in Syria, such as ISIL/ISIS will be conducted later in this thesis. In the following section the proxy nature of the War in Syria will be discussed.

\subsection{The War in Syria: A Proxy War}

Early on, the United States designated the Syrian Army as an oppressive group, condemning the whole of Syrian President Bashar al-Assad's government using fabricated evidence (Anderson 2016, Bartlett 2016). Such fabricated evidence included claims that during the election of President Bashar al Assad "voting only took place in government-controlled areas, and no credible election observers supported its outcome"(Bartlett, 2016), while in reality traffic jams caused many Syrians to travel on foot due to the "the tens of thousands flocking to 
vote" (Bartlett, 2014). This false evidence has served to justify the involvement of the United States and its allies against Syria as a sovereign state and has allowed the War in Syria to evolve seamlessly into a devastating proxy war (Bartlett, 2016). I will discuss two major separate instances of this fabrication that have occurred. The first instance was the Houla Massacre that took place on May $25^{\text {th }}$ 2012. During this massacre, 100 civilians were murdered in the village of Houla north-west of Homs in Syria (Anderson, 2016, p. 71). This massacre became centrally important to the 'Responsibility to Protect' discussions of western countries, who took the massacre as a launching point for further military interventions in Syria. England, France and the United States, (and later the United Nations Human Rights Council, UNHCR) attributed this massacre to the Syrian Army and held the Syrian government responsible despite indeterminate evidence (Anderson, 2016, p. 72-77). Notably opposition and abstentions from Russia, China, Cuba and India prevented United Nations Security Council (UNSC) action against the Syrian government despite the stance of the UNHCR with all opposing members arguing for a reconsideration of evidence and impartiality (Anderson, 2016, p. 78). Though no UNSC action took place, this fabricated evidence prompted western countries (especially the United States, Canada, England and France) to become involved in the War in Syria.

The second instance of fabrication came when the United States under the Obama Administration fabricated some of the evidence associated with the brutality of the Syrian government including the assertion that President Bashar al-Assad was responsible for the chemical weapons attack near Damascus on the $21^{\text {st }}$ of August 2013 (Anderson 2016, Hersh 2014). The United States' government and its closely affiliated Human Rights Watch group, along with the Saudi-backed 'Islamic Front' blamed the Syrian government and the Syrian Army of gassing children in Damascus. Hersh (2016) reports that there is a complete lack of evidence 
linking Syria to the Damascus chemical weapons attack and argues that Turkey and Saudi Arabia orchestrated the attack in order to draw the United States into a larger scale offensive against the Syrian Army. Upon review of much of the evidence which came from the Syrian government and other external sources, Anderson (2016) states that it is likely that the attack was orchestrated by al-Quaeda allied Jabhat Fatah al Sham (formerly known as the al-Nusra front), the 'Islamic Front' and Turkey. Anderson argues that the 'Islamic Front' received chemical weapons via Saudi intelligence chief, Prince Bandar bin Sultan, from Turkey and carried out the gas attack, and fabricated the photographs of "gassed" children (2016, p. 84). These photographs were used as proof by the United States' media of the Syrian gas attack (Anderson, 2016, p. 84). The fact that the Obama administration did not admit the existence of this new intelligence even when presented with it directly; speaks to their refusal to contradict their Turkish ally and associated economic interests in Turkey (Hersh, 2015). This studied refusal to acknowledge evidence casts doubt on many of the previous assertions of the United States about the oppressive nature of the Syrian Army and President Bashar al-Assad's Syrian government. In fact, the refusal to acknowledge the role of Saudi Arabia and Turkey "shows this to be another 'false flag' incident, designed to attract deeper foreign intervention" (Anderson 2016 p.86, Bartlett 2016). In the following section, the major participants in the conflict will be discussed.

\subsection{The War in Syria: Major Participants}

The Syrian Army is the official army of Syria and is responsible to the Syrian government. Since 2014 the Syrian Army has partnered with some local protection units manned by volunteers known as the National Defense Force (NDF) (Said, 2015). The Syrian Army has also received technical, financial, military and political support notably from Russia, Iran and Iraq as well as Hezbollah, a Shi'a Islamic group and political party based in Lebanon (Said, 2015). Since October 2015, the Syrian Army, backed by direct Russian military involvement, has 
made significant advances against the Islamic State of Iraq and the Levant/The Islamic State of Iraq and Syria (ISIL/ISIS), the allied Jabhat Fatah al Sham (formerly known as the al-Nusra front) and newly formed 'Islamic Front' and Rojava (Anderson 2016 \& Said 2015).

Other groups involved in the conflict are comprised of various domestic and extranational groups formed during the course of the War in Syria or who joined at a later time. The largest portion of the opposition is made up of the al-Qaeda affiliated Jabhat Fatah al Sham (formerly known as the al-Nusra front) that is allied with the Saudi-backed 'Islamic Front' a group composed of numerous other smaller Islamist groups, some of which formerly operated under the umbrella of the Free Syrian Army (FSA) (Fisk 2016, Hersh 2015). Fisk (2015) claims that early on in the conflict the United States and its North American and European allies incorrectly regarded the former FSA as a possible pro-western force to be used against the Syrian government, and thus explicitly supported its members through the provision of arms and training. The United States and its North American Treaty Organization (NATO) allies (including Canada, England and France) had designated the former FSA as a moderate force and provided sophisticated military support that greatly increased the total fighting capacity of its members (Anderson 2016 \& Fisk 2016 ). The FSA no longer operates as an independent force with its members having since joined the al-Qaeda affiliated Jabhat Fatah al Sham (formerly known as the al-Nusra front) and its ally the 'Islamic Front', ISIL/ISIS or the Syrian Army (Anderson, 2016). Thus, that western military support has been mainly displaced to Jabhat Fatah al Sham (formerly known as the al-Nusra front) and the 'Islamic Front'. Currently, both the Jabhat Fatah al Sham (formerly known as the al-Nusra front) and the 'Islamic Front' enjoy sophisticated western military support namely from Saudi-Arabia, Turkey and Qatar (Anderson, 2016). 
ISIL/ISIS is a Salafi jihadist militant group that follows an Islamic fundamentalist Wahhabi doctrine of Sunni Islam. ISIL/ISIS made expeditious military gains in Northern Syria in 2013 and as of mid-2014 controlled most of Northern Syria and had an estimated 50,000 fighters in Syria, including many non-Syrians (Al-Jazeera Media Network, 2014). ISIL/ISIS has been accused and criticized by the UNHCR and numerous foreign media outlets for abusing human rights and for expelling, imprisoning or executing non-Islamist militia groups, foreign journalists and aid workers (Reuters, 2016). Opposition to ISIL/ISIS has been in western media quite loudly and extensively voiced (Lowrie, 2015) and its impact both at home (see Skinner, 2016 for an example) and abroad (see Ellis, 2014 for an example). In reality however, western opposition has been quite fractured and arguably insufficient which has allowed for the spread and control of ISIL/ISIS and its autonomy over a third of Syria's land and most of Syria's oil and gas production (Anderson 2016 \& Cockburn 2014).

Reasons for this insufficient opposition are widely varied and heavily contested. According to Weiss (2014), Richter (2014) and Vinograd and Omar (2014), ISIL/ISIS has not been as intensely targeted by the Syrian Army since its presence was useful in framing the Syria question as one between Assad and jihad. This claim is contradicted by Hersh (2016) who argues that reason ISIL/ISIS was insufficiently opposed is because Turkey's government led by President Recep Tayyip Erdogan is "a vital, and hidden supporter of al-Nusra and ISIS” (p. 2). Allied with various western countries including Canada and the United States through the NATO coalition, Turkey's involvement in the support of ISIL/ISIS and Jabhat Fatah al Sham (formerly known as the al-Nusra front) in Syria remains unquestioned and even tacitly supported by those same western countries (Hersh, 2016). Weiss's claim is also rejected by Anderson (2016) who argues that ISIL/ISIS exists as a result of the creation of "a climate of resentment amongst 
orthodox Sunni Muslim communities" caused by western intervention in the Middle East (p. 101). Anderson (2016) further asserts that the United States uses this particular narrative to conceal its own responsibility for the creation and maintenance of ISIL/ISIS and to hide its complicity with this terrorist organization. According to Hersh (2007) cited in Anderson (2016) the United States planned to make use of "moderate Sunni states" (such as Saudi Arabia) to contain alleged "Shiia gains" in Iraq brought about by the 2003 United States invasion; in order to weaken Iran and Hezbollah and topple their Syrian ally (p. 102). The United States and its western allies such as Canada have both explicitly and tacitly supported ISIL/ISIS, attempting to use the group as a "key tool" against the Syrian government (Anderson, 2016). Simultaneously, these states are manipulating the fear of ISIL/ISIS terrorists at home and abroad in order to manufacture support and justify various political and economic agendas (Fisk, 2016).

In addition to the Syrian Army, the Jabhat Fatah al Sham (formerly known as the alNusra front), the now disbanded FSA and ISIL/ISIS a fourth group has shaped the development of the War in Syria. This is the newly semi-autonomous region of Rojava which is formed of four cantons: Jazira, Kobani, Shahba and Afrin (Al-Jazeera, 2016). Cockburn (2015) asserts that Rojava grew out of "the struggle of the 2.2 million Kurds, 10 per cent of the Syrian population, to create a Kurdish federal state in north-east Syria” (p. 3). Since 2012, the Kurds have been extraordinarily successful militarily and now control the 250 mile-long area between the Euphrates and the Tigris along the southern frontier of Turkey (Cockburn, 2015). The success of the Syrian Kurds is due to direct assistance from western countries such as the United States and Canada as "Kurdistan became the vanguard of the West's battle" against ISIL/ISIS (Fisk, 2015, p. 3). 


\subsection{The War in Syria: A Conclusion}

Following this brief description of the War in Syria, the intervention and influence of the United States and its allies in Syria on the available information about Syria becomes more apparent. Aylan serves as powerful fodder for the western media cannon and I argue that his photograph is used to tell particular stories about the War in Syria and the role of western countries such as the United States and Canada in the conflict. My focus for this thesis will be an examination of the Canadian media's manipulation of Aylan's photograph in an attempt to provide some critical engagement with the "truths" presented by the Canadian media in order to propagate a more accurate depiction of the War in Syria. In the following section I will discuss my research method and data sources. 


\section{Chapter: Methodology}

For this thesis I have chosen newspaper articles, from some of the top Canadian newspapers by circulation that have both an online and print format. The articles chosen (these texts are the first half of my data) are those that made explicit mention of Aylan Kurdi. I have limited the scope of the articles to those that were printed and released within 7 days of his death on September $2^{\text {nd }} 2015$. The top three photographs of Aylan, by Internet search hit frequency on Google.ca, are the second half of my data. In this section, I will first justify the choice of Aylan's particular case as the focus of this thesis, and then explain the choice of sources and data subject to analysis. I will also attempt to provide a thorough overview of my research methodology.

\subsection{Justification for Research Focus}

This thesis will use the case study as a method of analytic inquiry. Fairclough (2001) argues for the importance of the 'micro' event when looking to understand larger social trends since “ 'micro' actions or events, including verbal interaction, can in no sense be regarded as of merely 'local' significance to the situations in which they occur, for any and every action contributes to the reproduction of 'macro' structures" (Fairclough, 1995, p. 35). Similarly, Flyvbjerg (2001) reinforces the need for example based research in the social sciences. Case studies; according to Flyvbjerg (2001); grant researchers a "nuanced view of reality" and that “cases are important for researchers' own learning process in developing the skills needed to do good research" (p. 72). Furthermore, Flyvbjerg explains that the "power of the good example" is systematically underestimated in good research (p. 77). Aylan's case is a good example of an extreme case. Extreme cases, like Aylan's, “reveal more information because they activate more actors and more basic mechanisms in the situation studied" (Flyvbjerg, 2001). In choosing Aylan's case I hope to uncover more information about the actors and mechanisms that have shaped the Canadian media depictions of, and responses to, the Syrian refugee crisis. 
Aylan's photograph is a seminal photograph, just as his case is an extreme case. His photograph and death has undeniably influenced the western perception of Syrian refugees in Canada. Although Aylan's photograph is only one object in a field of many that are intended to support a particular narrative about western intervention of the Middle East and Arabs, I focus here solely on him due to the scope of this project. Indeed, I argue that Aylan's photograph can be considered by many the defining moment and image of the War in Syria and refugee crisis; just as the photograph "Accidental Napalm" can be considered the defining moment and image of the Vietnam War. The iconic nature of the "Accidental Napalm" photograph is "believed to reflect its influence on public attitudes toward the war, an influence achieved by confronting U.S. citizens with the immorality of their actions" and by constructing a particular viewer response which hastened the end of the U.S. involvement in the conflict (Hariman \& Lucaites, 2007, p. 173). As Hariman and Lucaites (2007) note: “Accidental Napalm” depicts a controversial moment in the Vietnam War that in hindsight marks a turning point in the support for and media framing of the conflict. Aylan Kurdi's photograph is similarly iconic and controversial and has greatly influenced public attitudes in Canada by confronting Canadian citizens with their responsibility for intervention in the conflict. Aylan Kurdi's photograph also marks substantial shifts in both the support for and media framing of the conflict. As Hariman and Lucaites (2007) argue that "Accidental Napalm" was the moment when the Vietnam War "crystallized in U.S. public consciousness"; so I argue that Aylan Kurdi’s photograph marked the crystallization of the War in Syria and refugee crisis "crystallized" into Canadian public consciousness (p. 207).

\subsection{Research Design Elements: Photograph Analysis}

The research process I chose for this thesis was twofold. I will now describe the objects of study, the data collection methods and the data analysis procedures for the first portion of my 
research. The first portion of my research focused on photograph analysis. Three photographs of Aylan Kurdi were the three objects of study for this first portion. These photographs all depict the corpse of Aylan Kurdi from various angles, two depict Aylan's corpse alone, and one depicts a law enforcement official carrying the corpse of Aylan Kurdi. I will describe these photographs broadly as the "face-down and feet near" photograph, the "face-down and face near" photograph" and the "carrying" photograph. These photographs were the top three photographs by search hit frequency on Google.ca after entering in the search term “Aylan Kurdi”. All three of these photographs chosen were taken by the Turkish photographer Nilufer Demir.

To analyze these photographs I first conducted a semiotic analysis of the image of Aylan Kurdi. My data analysis strategy for reading the images of Aylan Kurdi drew on the work on image semiotics of Sontag and on the work of Hariman and Lucaites that supplements Sontag, on seminal and iconic photographs. In her development of image semiotics, Sontag (1977) asserts "photographs alter and enlarge our notions of what is worth looking at and what we have a right to observe" (p. 3). Photographs not only tell us what we should be seeing and that we have a right to see it, but also have an "ethics or grammar of seeing" that structures how we interpret what we see (Sontag, 1977, p. 3). The semiotic analysis of photographs is thus focused on:

1. What we are looking at.

2. Where our attention should be.

3. What we should think or feel about what we are looking at.

Sontag's work on image analysis is supplemented by the work of Hariman and Lucaites (2007). Through their empirical studies on seminal and iconic photographs they have identified five factors that influence how an image becomes an iconic photograph. Hariman and Lucaites' (2007) considerable work on how people interpret and read photographs, combined with 
Sontag's photography theory will guide how I interpret the photograph of Aylan Kurdi as an iconic photograph central to the War on Syria. The first element Hariman and Lucaites (2007) identify that makes a photograph iconic is its inclusion of artistic and aesthetic conventionalities such as the rule of thirds, accurate proportions, lack of sharp contrasts etc. The second element is that iconic photographs function as a performance or reproduction with the photograph recreating "recognizable moments of social performance" (Hariman \& Lucaites, 2007, p. 32). The third element of an iconic photograph is that it directs an observer's understanding along particular lines, making connections with other aspects of social knowledge to tell an easily understandable story (Hariman \& Lucaites, 2007, p. 35). It is in this element that the idea of a common understanding is broached. An iconic photograph must resonate in a similar manner with a large variety and number of people located in the same social setting. The fourth element of an iconic photograph is that it evokes a strong emotion (Hariman \& Lucaites, 2007, p. 35). This is tied with the previous element in that a specific emotional connection can only be elicited in those who share a similar foundation of social cues and social knowledge. The final element of an iconic photograph, its ability to suggest a conflict and possible resolution, pertains directly to the image of Aylan Kurdi. Hariman and Lucaites (2007) argue that an iconic image is an "aesthetic resource for performative mediation of conflicts" and suggests how things were, how things are, and how things might be (p. 37). Aylan's photograph suggests that the conflict has caused his death, that he is currently abandoned on the beach and that there is the need to resolve this issue by "picking up" abandoned refugees.

Aylan's photograph has become the defining image of the War in Syria, especially between the West and its allies through its instantaneous take-up by the western media. Aylan's photograph follows certain artistic conventions depicting an archetypal white skinned child in 
primary colored clothing, reproduces his drowning and death for the audience, connects his death to his escape from the War in Syria suggesting a conflict so atrocious that a life-threatening choice was made, makes the viewer feel that this might have been their child, and calls for change with regards to the treatment of refugees from Syria. In sum, Aylan's photograph adheres to the conventions of the iconic photograph as described by Hariman and Lucaites (2007) as "an aesthetically familiar form of civic performance coordinating an array of semiotic transcriptions that project an emotional scenario to manage a basic contradiction or recurrent crisis” (p. 29).

\subsection{Research Design Elements: Discourse Analysis}

As mentioned, the research process I chose for this thesis was twofold. I will now describe the objects of study, the data collection methods and the data analysis procedures for the second portion of my research. The second portion of my research focused on discourse analysis where I conducted a critical discourse analysis of the newspaper articles, from some of the top Canadian newspapers by circulation that have both an online and print format. The articles chosen were newspaper articles only, from one of the top 25 Canadian newspapers by circulation, that included the search term "Aylan Kurdi" and were published and released within 7 days of Aylan Kurdi's death on September $2^{\text {nd }} 2015$. The selection frame for this thesis was chosen to keep the articles analyzed to a manageable number for the time constraints. I retrieved these articles from Carleton University's online article databases: Summon and Lexis Nexus. 10 articles were found using the Summon database, while 159 articles were found using the Lexis Nexus database. The articles came from The Globe and Mail, the Toronto Star, the National Post, The Vancouver Sun, The Spectator, The Province, the Calgary Herald, the Winnipeg Free Press, the Ottawa Citizen, The Edmonton Journal, The Chronicle-Herald and The Gazette.

My data analysis procedures for this thesis draws on the work of Fairclough and can be broadly divided into an analysis of discourses of departure of refugees from Syria and an 
analysis of discourses of arrival of Syrian refugees in Canada. In his development of Critical Discourse Analysis (CDA), Fairclough draws from the work of Goffman that centers on the uncovering of the "taken-for-granted" assumptions that make up a person's naturalized Background Knowledge (or BGK) about a particular event. According to Fairclough (1995): the "more dominant...[a] particular representation of a social relationship, the greater the degree of naturalization of its associated practices" (p. 33). Callaghan and Schnell (2001) develop a form of frame analysis that shares much with the associated practice of CDA. Callaghan and Schnell (2001) argue that the media utilize certain frames to "purposely seek to cap the range of policy information and alternatives, and therefore attempt to control public opinion" (p. 184). In my project I sought to employ qualitative critical discourse analysis with a focus on how the media frames certain issues.

To perform this qualitative critical discourse and frame analysis, I coded around two central nodes: arrival and departure. I first printed my articles, and read all of them without annotating them at all. This helped to ensure that I had removed all unwanted articles and had collected articles that aligned properly with my search parameters. I then ran all the articles through the NVivo qualitative data analysis software package. With the software I was able to do a text search of all my articles of the word "arrive" and other stemmed words such as: come, here, settle, immigrate, settling, establishment, established, immigration, immigrated, arriving, immigrants, arrived, settled, establish, coming, immigrating, arrived, comes, immigrant, arrivals, immigrate and arrival. I set the parameters of my text search to retrieve 10 words on either side of the search term and then saved all these retrieved pieces of text to a word document. I repeated this text search of all my articles with the word "leave" and other stemmed words such as: departure, exit, going, migrate, migration, leaving, go and migrated. Once again, I set the 
parameters of my text search to retrieve 10 words on either side of the search term and then saved all these retrieved pieces of text to a word document. Additionally, I created word-trees using two subsets of my stemmed words. The first subset consisted of arrival, arrive, arrivals, arriving, arrives and the second subset of leave and leaving. The word trees allowed me to see how these words were used comparatively in a graphical format. Both the text search and word tree functions made up my process of primary-cycle coding (Tracy, 2013, p. 189).

I then went through my articles with different colors and highlighted portions of the text that mention the arrival and departure of Syrian refugees. This was my process of secondarycycle coding (Tracy, 2013, p. 189). The passages of my article that include a combination of both arrival and departure references were denoted by all the appropriate highlighter colors as lines in the margin. Sentences that specifically describe some type of experience were highlighted in the single corresponding color. My process of secondary-cycle coding allowed me not only to check the primary-cycle coding performed by the NVivo program but also allowed me to gain some quantitative data about language use and to theorize about some of the over-arching themes of my data (Tracy, 2013, p. 194). I then took notes in the margins about how certain highlighted passages described arrival or departure, further breaking down my secondary-cycle coding into more informative pieces through processes of tertiary-cycle and quaternary-cycle coding. I will turn to a discussion of the findings of my research in the following section. 


\section{Chapter: Research Findings}

\subsection{Photograph Analysis Findings}

I analyzed three images of Aylan Kurdi in the photography analysis portion of this thesis. As discussed above, I used the work of both Sontag and Hariman and Lucaites to conduct the image analysis on these three photographs. Sontag, Hariman and Lucaites provide a series of questions with which to guide photograph analysis. I used their questions as a starting point. Using my answers to each of these questions as guide, I then built my complete qualitative analysis of the photograph. In their work with iconic images Hariman and Lucaites pose the following five questions:

1. Is the photograph pleasing (artistically) to look at?

2. Is the photograph a realistic depiction?

3. Does the photograph direct understanding in a particular direction?

4. Does the photograph produce a strong emotion?

5. Does the photograph suggest a timeline? Does the photograph suggest how things were, how they are and how they might be?

In her work on image semiotics, Sontag poses the following three questions:

1. What we are looking at?

2. Where should our attention be?

3. What we should think or feel about what we are looking at?

As stated above I examined three photographs of Aylan Kurdi. Broadly these can be described as the "face-down and feet near" photograph, the "face-down and face near" photograph" and the "carrying" photograph. All three of these photographs were taken by Turkish photographer Nilufer Demir and have become iconic photographs that represent the War in Syria, with the second "face-down and face near" photograph having become arguably the 
most recognizable and most iconic. Additionally, as stated above, while I conducted my photograph analysis on high-resolution versions of Aylan's photograph, I have deliberately chosen not to reproduce a full-color or full-scale version of Aylan's photograph anywhere in this thesis. By reducing the quality of my reproductions I deliberately reduce the impact of this photograph.

I will now present my analysis of each photograph in turn. I began my image analysis with the "face-down and feet near" photograph which is below:

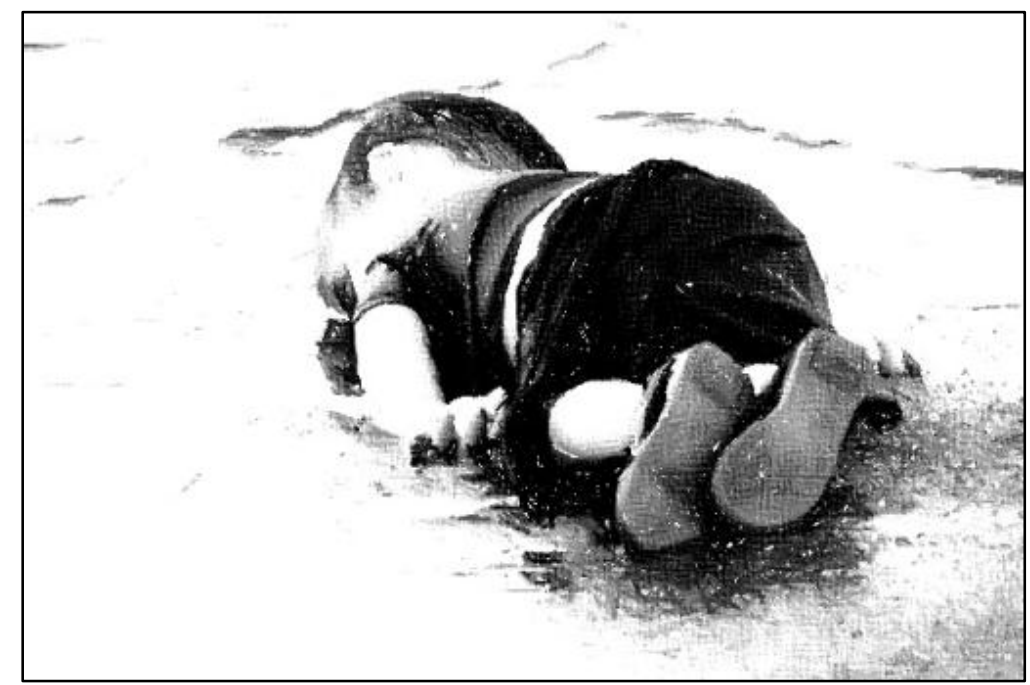

Figure 2: Aylan Kurdi in Bodrum, Turkey with his face-down and feet near the viewer.

This photograph followed several artistic conventions. The first was that this photograph strictly adheres to the rule of thirds, with Aylan's shoes, head and the white space in three distinct vertical thirds and Aylan's head, torso and feet in three distinct horizontal thirds. This serves to draw the eye from the bottom right corner where his feet are to his face and enables the viewer to focus on Aylan's partially submerged face. The second was that the photograph included a large amount of negative space, this served to make Aylan's body the clear focus of the photograph. The primary colours in the positive space of this photograph, which include Aylan's red t-shirt and blue shorts, also serve to draw the eye and retain viewer focus on Aylan. 
Upon first glance this photograph appears to realistically depict a sleeping toddler. The blue shorts, red shirt and tiny pair of sneakers are rendered in detail in this photograph and serve to underscore the realism. The photograph is a realistic depiction of a toddler's body and is easily recognizable as such. Toddlers often sleep in strange positions, looking like they have just flung themselves down to sleep. Aylan on the beach looks peacefully asleep, until the viewer's eye is drawn to his partially submerged face among the waves. Then the truly disturbing content of the photograph is apparent. This photograph draws the viewer's attention from the sleeping posture of Aylan to his partially submerged face. This tells the viewer that they are not looking at a sleeping toddler, but are in fact looking at a tiny corpse on a beach.

The strong emotional response comes when the viewer realizes that what they first thought was a sleeping child is actually a dead child. The sickening realization over the injustice of a dead child is the source of the strong surge of empathy felt by the viewer when looking at the photograph. For white Canadian parents, Aylan's pale skin heightens their empathy, as they are able to picture their own children at that age and feel sympathetic for Aylan's parents. The strong empathy felt by the viewer heightens the emotional reaction to the photograph.

In this photograph Aylan appears to have washed up recently on the beach. He looks as if he was playing on the beach mere hours before but is now dead. This suggests the immediacy of the Aylan's death. There is the sense that had rescue personnel arrived but a few hours earlier that they might have been able to save Aylan's life. This suggests that the lack of intervention or delayed intervention in the War in Syria has caused Aylan's death and that in the future earlier and timelier action is needed to prevent further tragedy.

In sum, in this photograph viewers are looking at a child who appears sleeping but is in fact dead. Attention should be on Aylan's face, which is partially submerged and highlights the 
disturbing nature of the image. This photograph causes viewers to empathize with the parents of Aylan and viewers have a desire to intervene earlier to prevent the occurrence of more tragedies of this kind.

The second image I analyzed is arguable the most iconic photograph of all of the photographs of Aylan. The "face-down and face-near" photograph is below:

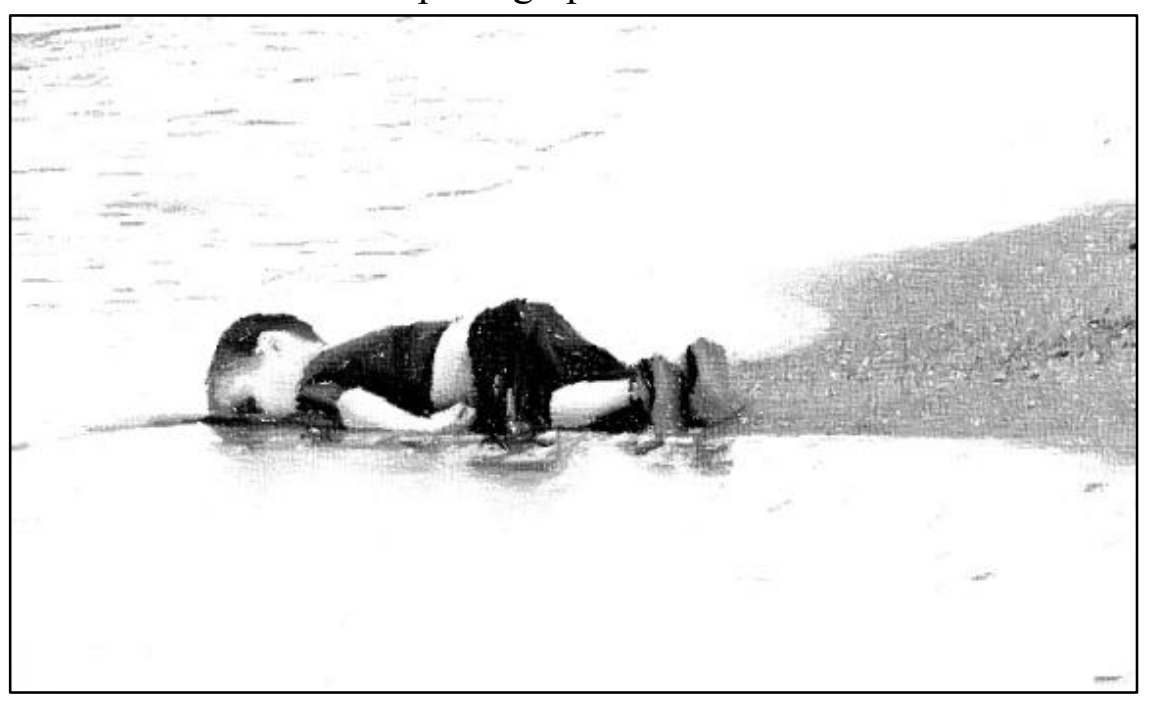

Figure 3: Aylan Kurdi in Bodrum, Turkey with his face-down and face near the viewer.

Like the first photograph, this photograph also followed several artistic conventions. The first was that this photograph strictly adheres to the rule of thirds, with Aylan's head, Aylan's hip bone and the beach sand, in three distinct vertical thirds and the waves, Aylan and the water in three distinct horizontal thirds. The zig-zag shape of the wave's edge draws the viewer's eye to his partially submerged face. 


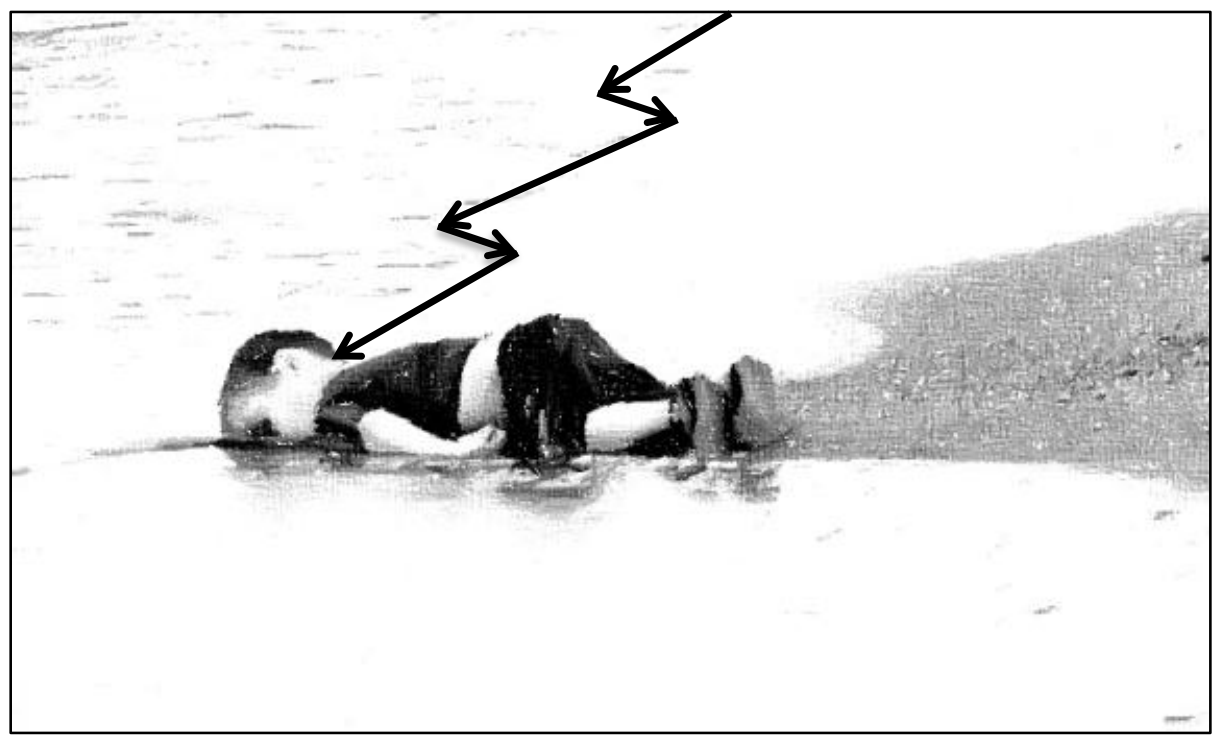

Figure 3a: Aylan Kurdi in Bodrum, Turkey with his face-down and face near the viewer.

Like the first photograph, this photograph is a realistic depiction of a toddler. Unlike the first photograph, there is no confusion about this being a sleeping toddler. The wider angle of the shot includes clearly defined waves and water in the frame and Aylan's submerged face is the focus of the photograph. The viewer is instantly aware that this photograph is of a dead child and understands that this is a corpse that has washed up on the beach.

In a similar way to the first photograph, the strong emotional response over the injustice of a dead child comes with a sense of empathy felt by the viewer when looking at the photograph. For white Canadian parents, Aylan's pale skin heightens their empathy, as they are able to picture their own children at that age and feel sympathetic for Aylan's parents. Aylan's hip which is visible out above his shorts, suggests that his pants need tugging up. This evokes the daily routines of dressing and caring for a toddler that parents understand well. This small detail makes Aylan's photograph appear even more realistic.

As in the previous photograph, Aylan appears to have washed up recently on the beach. He looks as if he was playing on the beach mere hours before but is now dead. This suggests the 
immediacy of the Aylan's death. There is the sense that had rescue personnel arrived but a few hours earlier that they might have been able to save Aylan's life. This suggests that the lack of intervention or delayed intervention in the War in Syria has caused Aylan's death and that in the future earlier and timelier action is needed to prevent further tragedy. This photograph makes you feel helpless and guilty of doing nothing to prevent this tragedy but also like there might be something that could be done to help to "pick up" Aylan off of the beach.

In sum, in this photograph viewers are looking at a dead child who has washed up on a beach. Viewer attention should be on his face, which is partially submerged highlighting the disturbing nature of his deceased state. Upon looking at this photograph, viewers empathize with the parents of Aylan and have a desire to intervene earlier to prevent the occurrence of more tragedies of this kind. Viewers strongly feel the need to "pick up" and comfort Aylan and other children like him.

The final photograph I analyzed was the "carrying" photograph, which is below:

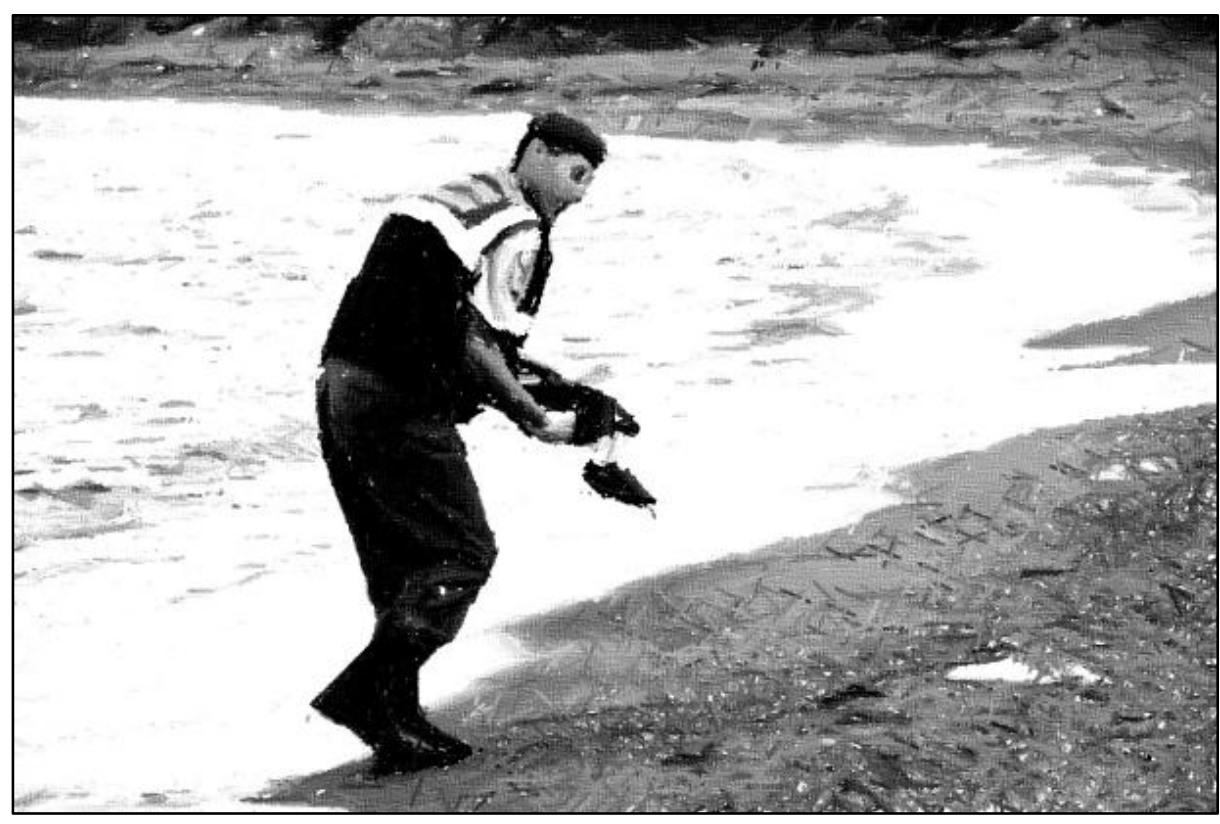

Figure 4: Aylan Kurdi in Bodrum, Turkey being carried. 
As in the first two photographs, this photograph also followed several artistic conventions. The first was that this photograph strictly adheres to the rule of thirds, with the law enforcement official in the first vertical third of the image and the following two vertical thirds of the photograph filled with sand and waves. The law enforcement official's face, Aylan's body, and the paramilitary officer's feet are in three distinct horizontal thirds. These horizontal thirds are emphasized by the diagonal shapes of the wave and shore edges draw the eye to the paramilitary officer and Aylan's corpse.

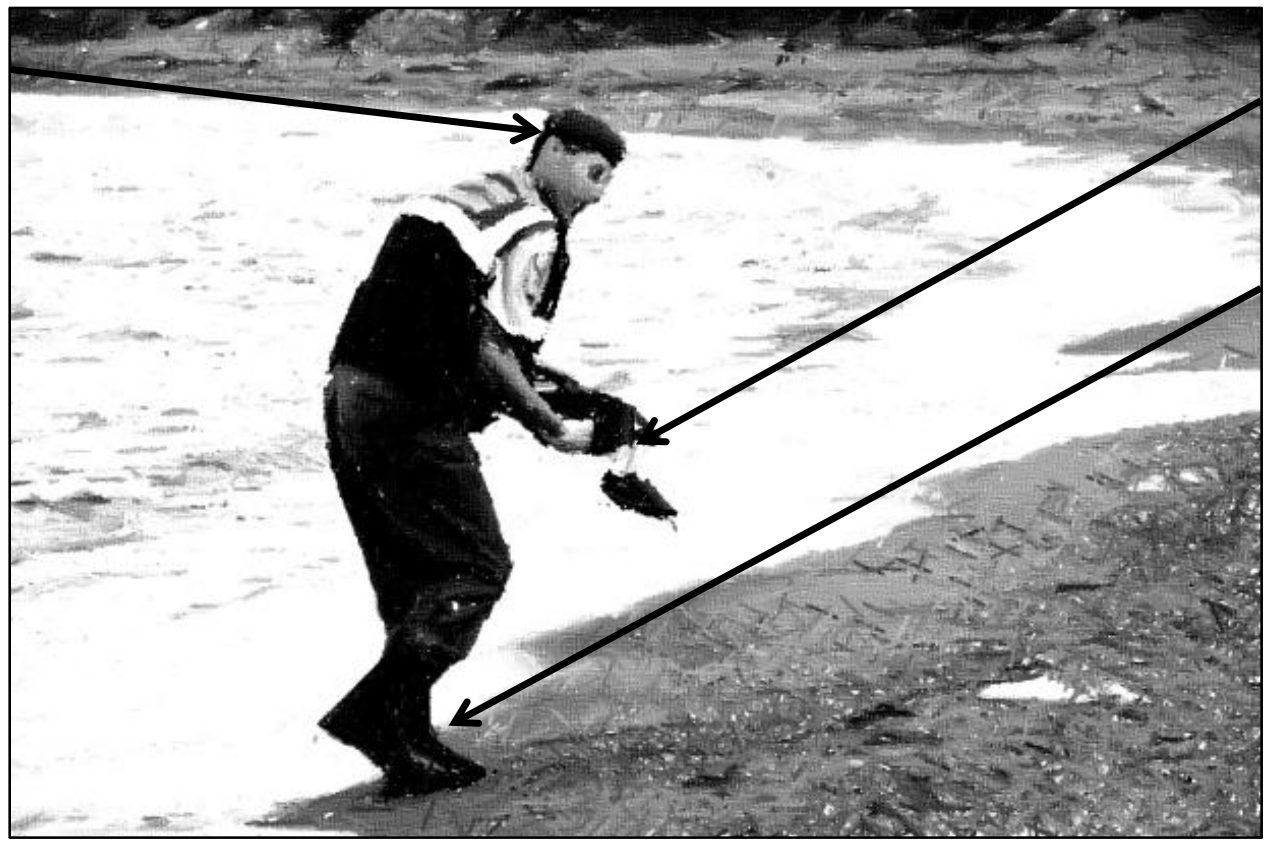

Figure 4a: Aylan Kurdi in Bodrum, Turkey being carried. The diagonal lines draw the viewer. focus to Aylan's corpse, the paramilitary officer's face and to his walking feet. In this photograph there is a clearly recognizable law enforcement official. He is recognizable by his military combat boots and visibility vest, as well as by the embroidered insignia on his shoulder. Though it is not clear from this photograph which country or organization he works for, his role as a law enforcement official is clear. This photograph is also a realistic depiction of a child being carried by an adult. In a similar way to the first photograph, 
the child could be sleeping. The stark beach setting and the fact that it is a law enforcement official carrying a child tells viewers that this is a dead child and not a sleeping child.

In a similar way to the first two photographs, the strong emotional response to the injustice of a dead child also comes with empathy felt by the viewer when looking at the photograph. For white Canadian parents, Aylan's pale skin heightens their empathy, as they are able to picture their own children at that age, perhaps when carrying them sleeping to their beds and thus feel sympathetic for Aylan's parents. The sorrow and resignation evident in the face of the law enforcement official serves to heighten the sorrow and empathy of the viewer.

Unlike the previous two photographs, the viewer is unable to see much of Aylan and thus is unsure of how he arrived on the beach to be carried by the law enforcement official. However, the action of the law enforcement official seems to be the right course of action. This suggests that the lack of intervention or delayed intervention in the War in Syria has caused Aylan's death and that in the future earlier and timelier action is needed to prevent further tragedy. This photograph suggests that something must be done to "pick up" Aylan and others like him off of the beach.

In sum, in this photograph viewers are looking at a law enforcement official carrying a dead child. Viewer attention should be on Aylan's corpse and on the face of the law enforcement official. Upon looking at this photograph, viewers empathize with the parents of Aylan and have a desire to intervene or act as soon as possible to prevent the occurrence of more tragedies of this kind. As in the previous images, viewers strongly feel the need to "pick up" and comfort Aylan and other children like him.

\subsection{Discourse Analysis Findings}

I analyzed a total of 168 newspaper articles that appeared in The Globe and Mail, the Toronto Star, the National Post, The Vancouver Sun, The Spectator, The Province, the Calgary 
Herald, the Winnipeg Free Press, the Ottawa Citizen, The Edmonton Journal, The ChronicleHerald and The Gazette. These are some of the top Canadian newspapers by circulation that have both an online and print format. The articles chosen were newspaper articles that included the search term "Aylan Kurdi" and were published and released within 7 days of Aylan Kurdi’s death on September $2^{\text {nd }} 2015$. I retrieved these articles from Carleton University's online article databases: Summon and Lexis Nexus. 10 articles were found using the Summon database, while 159 articles were found using the Lexis Nexus database.

As previously mentioned, in my project I sought to employ qualitative critical discourse analysis defined by Fairclough (1995) as the uncovering of "taken-for-granted" assumptions that make up a person's naturalized Background Knowledge (or BGK) about a particular event. I also applied the work of Callaghan and Schnell (2001) who argue that the media utilize certain frames, or ways of representing a social relationship, to manipulate and control public perceptions. The qualitative critical discourse and frame analysis portion of my project examined how the Canadian news media manipulated the death of Aylan Kurdi to reinforce a particular narrative of the War in Syria.

Also discussed above was my process of qualitative critical discourse and frame analysis. In addition to the process discussed I also made use of the NVivo qualitative data analysis software package and created word-trees using two subsets of my stemmed words. The first subset consisted of arrival, arrive, arrivals, arriving, arrives and the second subset of leave and leaving. The word trees allowed me to see how these words were used comparatively in a graphical format. Both the text search and word tree functions made up my process of primarycycle coding (Tracy, 2013, p. 189). Examples of the word trees for "arrive" and "leave" can be found below. 


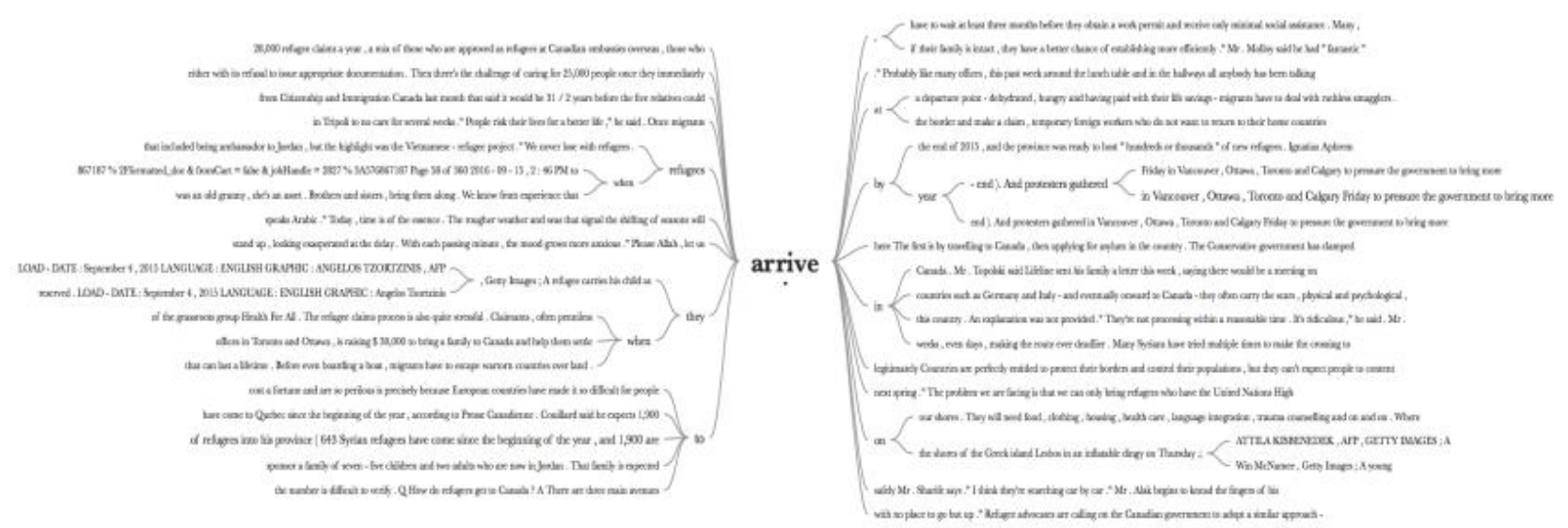

Figure 5a: NVivo created word-tree depicting some word associations with "arrive".

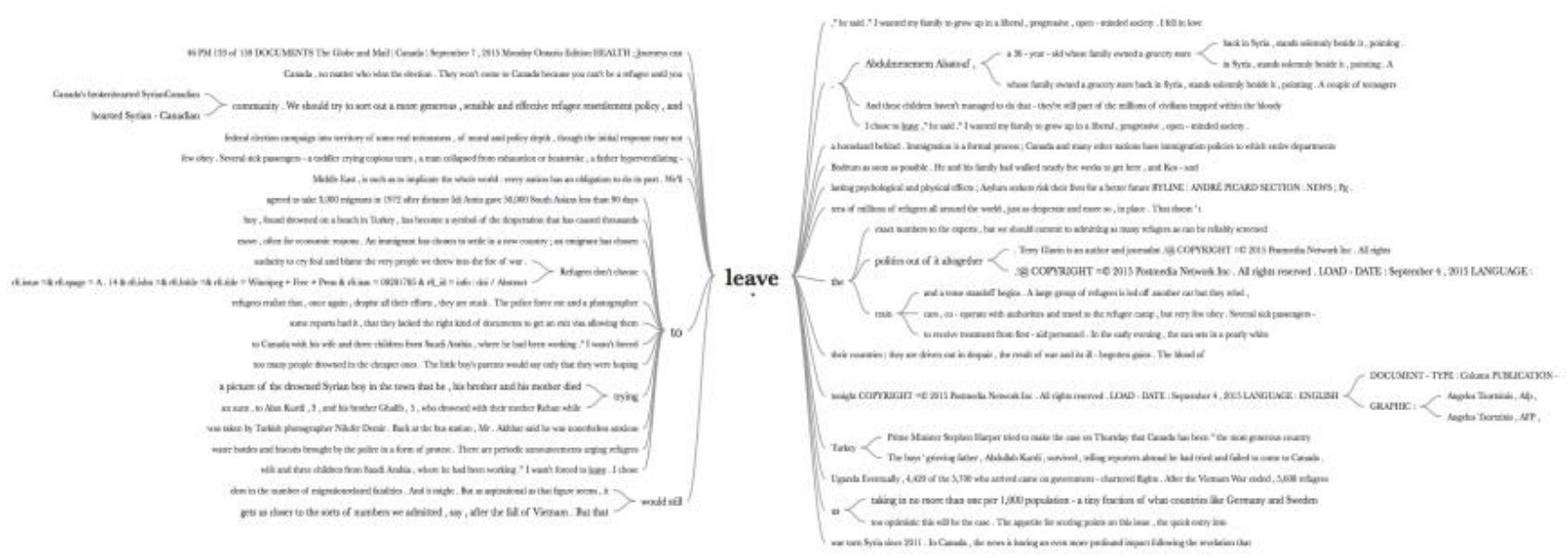

Figure 5b: NVivo created word-tree depicting some word associations with "leave".

As mentioned in the discussion of the details of my research above, I then went through my articles with different colors and highlighted portions of the text that mention the arrival in Canada of Syrian refugees (yellow highlighter) and the departure of Syrian refugees from Syria (pink highlighter). This was my process of secondary-cycle coding (Tracy, 2013, p. 189). The passages of my article that include a combination of both arrival and departure references were denoted by all the appropriate highlighter colors as lines in the margin. Sentences that specifically describe some type of experience were highlighted in the single corresponding color. I took notes in the margins about how certain highlighted passages described arrival or departure. This allowed me to perform tertiary-cycle and even quaternary-cycle coding and gain more 
specific insight into how the arrival in Canada of Syrian refugees and the departure of Syrian refugees from Syria is being discussed. My process of secondary-cycle and tertiary-cycle coding allowed me not only to check the primary-cycle coding performed by the NVivo program but also allowed me to gain some quantitative data about language use and to theorize about some of the over-arching themes of my data (Tracy, 2013, p. 194). A diagram of the various cycles of coding and the subsequently created data-subsets can be found below along with a sample of highlighted and annotated text.

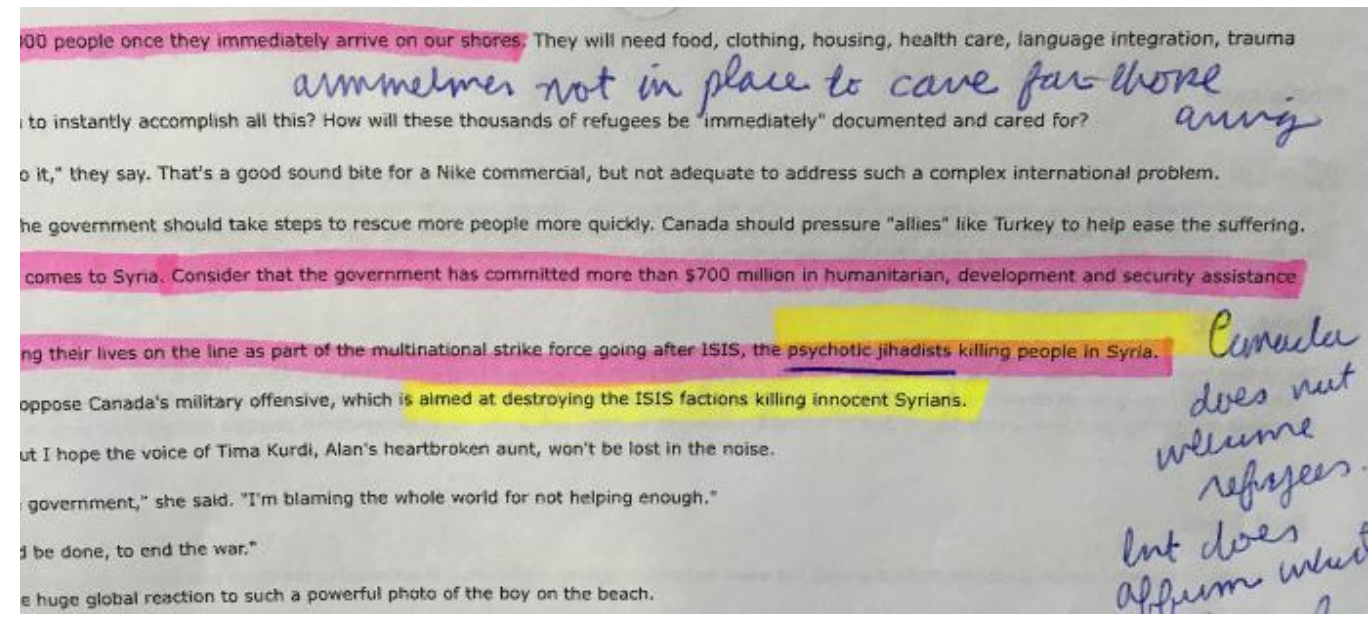

Figure 6: Highlighted and Annotated Text.

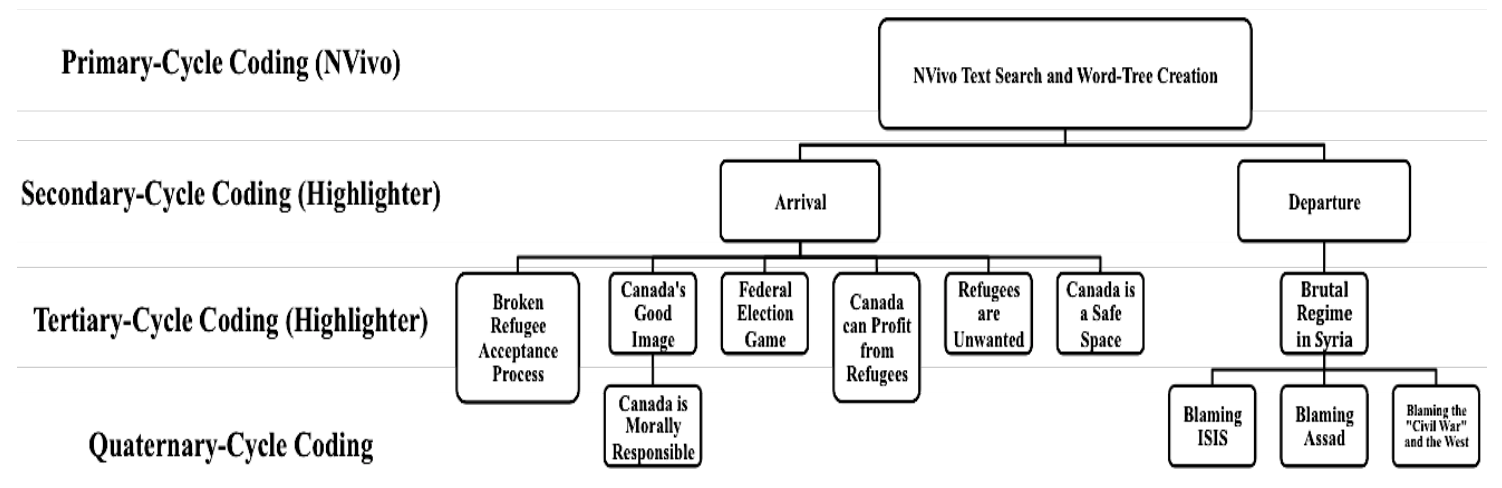

Figure 7: Diagram of Discourse Analysis Coding Process. 
As seen above in Figure 7, I sorted the textual data of both arrival and departure into subgroups that more specifically reflected its content. Under arrival I organized the article text data into six main subgroups: "broken refugee acceptance process", "Canada's good image", "federal election game", "Canada can profit from refugees", "refugees are unwanted", and "Canada is a safe space". I further broke down "Canada's good image" into "Canada is morally responsible". As seen above under departure I organized the data into one main subgroup: "brutal regime in Syria". I further broke down this group into "refugee crisis is invisible", "Assad is a demon" and "Canada created crisis". These divisions and subgroups evolved from multiple close readings of each article and from the collection and organization of relevant quotes and passages from those articles. These divisions and subgroups reflect the framing of the arrival in Canada (of Syrian refugees) and the departure from Syria (of Syrian refugees) by the Canadian news media in the 168 newspaper articles that I examined. These articles frame the death of Aylan Kurdi in particular way, and use the presentation of his death to draw connections to various tropes and assumptions (i.e. naturalized Background Knowledge or BKG) that exist in the Canadian public consciousness about the departure of Syrian refugees from Syria and of the arrival of Syrian refugees in Canada.

Fairclough notes that focusing on the on the uncovering of the "taken-for-granted" assumptions that make up a person's naturalized Background Knowledge (or BGK) about a particular event is central to conducting Critical Discourse Analysis (CDA). Fairclough (1995) notes that there are four dimensions of a person's naturalized Background Knowledge (BGK) base upon which people draw to understand and interpret events: "a common and naturalized knowledge of language codes", "of principles and norms of language use", "of situation" and "of the world" (p. 33). By examining each of my framing categories with these dimensions of the 
Background Knowledge (BGK) base, I attempt to "de-naturalize" and make visible the underlying assumptions that exist in the texts and structure the interpretation of those texts. As Fairclough notes, "critique is essentially making visible the interconnectedness of things" and thus investigating what messages and meanings underlie text helps to investigate what messages and meanings are shared and propagated by the Canadian news media which in turn determine what messages are received and understood and internalized by the Canadian public (p.36).

Callaghan and Schnell (2001) hold that framing effects occur when a multidimensional issue, such as the arrival of Syrian refugees in Canada, can be presented in "multiple packages or thematic slants" (p. 185). Callaghan and Schnell (2001) state that "frames define the problem, diagnose its cause, offer and justify treatments for the problem, and predict their likely effects" thus neatly packaging a messy or complex issue into easily digestible bites of information with apparently clear messages (p. 185). By examining the various frames present in the texts I examined, I seek to make visible the underlying assumptions used by the media to "frame" the issues in certain ways and thus to manipulate and mold reader understanding of Syrian refugees. I will now examine each of the various framings of the departure of Syrian refugees from Syria and of the arrival of Syrian refugees in Canada in turn. I will attempt to draw out the four dimensions of the naturalized Background Knowledge (BGK) base and to make visible the way the media has framed and structured the various issues at play.

\subsection{Arrival of Syrian Refugees in Canada}

\subsubsection{Broken Refugee Acceptance Process}

What I have called the "Broken Refugee Acceptance Process" was one dominant framing of the arrival of Syrian refugees in Canada. I identified three principal ways that the newspaper articles accomplished this framing. The first approach asserted that it was impossible to settle 
Syrian refugees in Canada, due to lack of social and institutional support. Smyth (2015) wrote in

\section{The Province:}

“...just how do we accept 25,000 refugees "immediately," anyway? How do we immediately accept and settle 10,000?” (p. A4).

The phrase "just how" and the quotation marks around "immediately" follow language norms that suggest the author's incredulity over Canada's ability to settle refugees. Smyth continued:

“Then there's the challenge of caring for 25,000 people once they immediately arrive on our shores. They will need food, clothing, housing, healthcare, language integration, trauma counselling and on and on. Where is the plan from Mulcair and Trudeau to instantly accomplish all this? How will these thousands of refugees be "immediately" documented and cared for? They have offered no detailed plan. "Just do it," they say. That's a good sound bite for a Nike commercial, but not adequate to address such a complex international problem.” (2015, p. A4).

In this segment the phrase "on and on" assumes the understanding of the audience that the needs of refugees are a never-ending list and will draw heavily on the social programs and benefits that Canadian citizens enjoy. The phrase "challenge of caring" frames the arrival of refugees as a problem that may have a difficult solution or may lack a solution entirely. Thus this passage shapes the understanding of the situation for readers by insinuating that refugees worldwide are always a drain on the system, and that the provision of state sponsored care will be an impossible burden for Canada. The final statement of this passage uses Nike's popular commercial tagline to demonstrate that the settlement of refugees doesn't conform to any pithy slogans and is instead monstrously complex. Readers are made to understand that Syrian refugee settlement in Canada just can't be done. Additionally, the constant iteration and re-iteration of the number of refugees 
that need to be settled by Smyth (2015) emphasizes the seemingly insurmountable task of refugee settlement. Rather than state that this number of refugees would fill less half the number of seats in the Rogers Centre, Smyth attempts to emphasize the number as too large to be accommodated on Canadian soil. Readers come to understand that that number is a huge and overly ambitious number of refugees to settle.

Interestingly, Smyth (2015) also questions how refugees will be "documented". This shifts the focus away from Smyth's arguably emotional play in the following phrase "cared for", and turns the conversation towards Canada's security concerns over the entry of unidentifiable persons. Documentation does not contribute to the health, safety and wellbeing of newly arrived refugees. If providing immediate care for refugees is the top priority, then their documentation is secondary to their immediate needs of "food, clothing, housing, healthcare" etc. This mention of documentation draws on the collective understanding of documentation as proof of identity. By mentioning documentation, Smyth (2015) makes claims about the need for refugees to prove who they are before being able to access the social goods and services provided by Canada for their care. This mention of documentation draws on the collective understanding of documentation as proof of identity. Documenting refugees or requiring their documentation before they are able to cross national borders is understood globally to be a means of controlling the population of refugees and is done primarily with the goal of securing a nation's borders and excluding the unwanted population.

A second approach under the "Broken Refugee Acceptance Process" frame was a presentation of the refugee acceptance process as fraught with deliberate hurdles and obstacles that made the acceptance of refugees a virtual impossibility. In numerous articles, an attempt was made to underscore the emotional impact of these obstacles and words that connote emotions or 
feelings were used to describe the acceptance process. Phrases such as "her distraught recounting of her attempts to bring family members to Canada" (Casey \& Omand, 2015, p. A4) or "waited an agonizing 11 years" (Hui, 2015, p. A14) or "that level of frustration and disappointment" (Berthiaume, 2015, p. A1) or "maddeningly slow process" (Dhillon, 2015, p. S1) all lead readers to connect emotionally to the difficulty of the process. The words "distraught", "agonizing", "frustration", "disappointment" and "maddeningly" are all commonly understood to connote negative emotional experiences and readers are thus able to interpret the text in a similar manner.

The presentation of the refugee acceptance process as fraught with difficulty was also done by introducing elements that rely on common pieces of knowledge held by most readers. For example, the phrase "the Orwellian aspects of refugee policy" (Denton, 2015, p. A1) forces the reader to draw a connection between the refugee acceptance process and George Orwell's depiction of a dystopic futurescape in his novel 1984 in which constant surveillance, bureaucratic totalitarianism and brutal punishments are the norm.

Finally, the presentation of the refugee acceptance process as fraught with deliberate difficulty was done by frequent references to a commonly held perception that bureaucracy is necessarily complex and burdened by mountains of paperwork peppered with jargon that impedes understanding. This relied on the reader understanding of bureaucracy and on reader experiences of completing government paperwork in the past. Phrases such as "a system that was designed to fail" (Glavin, 2015, p. A13) or "the Syrian refugee crisis has exposed a wall of bureaucratic hurdles" (Fine, 2015, p. A1) or "that long delay and lengthy process" (Black, 2015, p. A7) or "soul-destroying bureaucratic entanglements" (Mason, 2015, p. S1) or "ridiculously burdensome" (Lamey, 2015, p. B7) all indicate that excessively complex applications and a poorly designed and implemented system were responsible for the difficulty of accepting Syrian 
refugees in Canada. One text even mentioned that refugees are "having a bad consumer experience at the Canadian shop window" (Delacourt, 2015, p. IN2) suggesting that processing refugees is as simple as selling a product and servicing a customer, and that the refugee acceptance system is so poorly designed and managed that it is unable to complete even the most basic of tasks. Throughout this discussion of bureaucratic hurdles, the focus and criticism did not rest entirely on Canada. There was much condemnation of foreign offices and United Nations agency processing times with articles describing the "long waits a visa offices abroad" (Fine, 2015, p. A1) and the "red tape [and] bottlenecks some of which are the fault of transit countries and the United Nations" (Delacourt, 2015, p. IN2). These statements shift the onus and responsibility for the inability to process refugee applications quickly to other institutions and environments and serve to reduce the scrutiny on Canadian policy and governmental actions.

The third and final approach under the "Broken Refugee Acceptance Process" frame was a presentation of the refugee acceptance process as responsible for the deaths of Syrian refugees, such as the deaths of Aylan and his family. This approach drew on common understandings of Canadian bureaucracy and government as slow to adapt to change, and texts that took this approach suggested that these bureaucratic delays cost lives. Phrases such as "that is why their plans to obtain G5 approvals...were doomed - and the family ended up boarding that boat" (Glavin, 2015, p. A13) or "it is a fact that restrictive asylum policies fuel irregular migration" (Smith, 2015, p. A19) suggest that the lethargic Syrian refugee acceptance process was directly responsible for Aylan and his family's choice to rent seats in an inflatable dinghy and cross the Aegean sea in middle of the night. This undeniably reduces the complexity of the situation in which the Kurdi family found themselves and detracts from an accurate presentation of their motivations for migration. Other articles also suggested that the slow acceptance process was 
directly connected to the death of Syrian refugees in far more blunt a manner. Phrases such as "let [Aylan's body] remind us of the terrible costs of bureaucracy, of dithering and of delay" (Cukier, 2015, p. A19) and "Many refugees lack the proper paperwork. Many die for it." (If Canada cares about refugees let's show it, 2015, p. B6) forcefully argue that the slow acceptance process killed Aylan and his family, drawing a sharp connection between bureaucratic delay and refugee death.

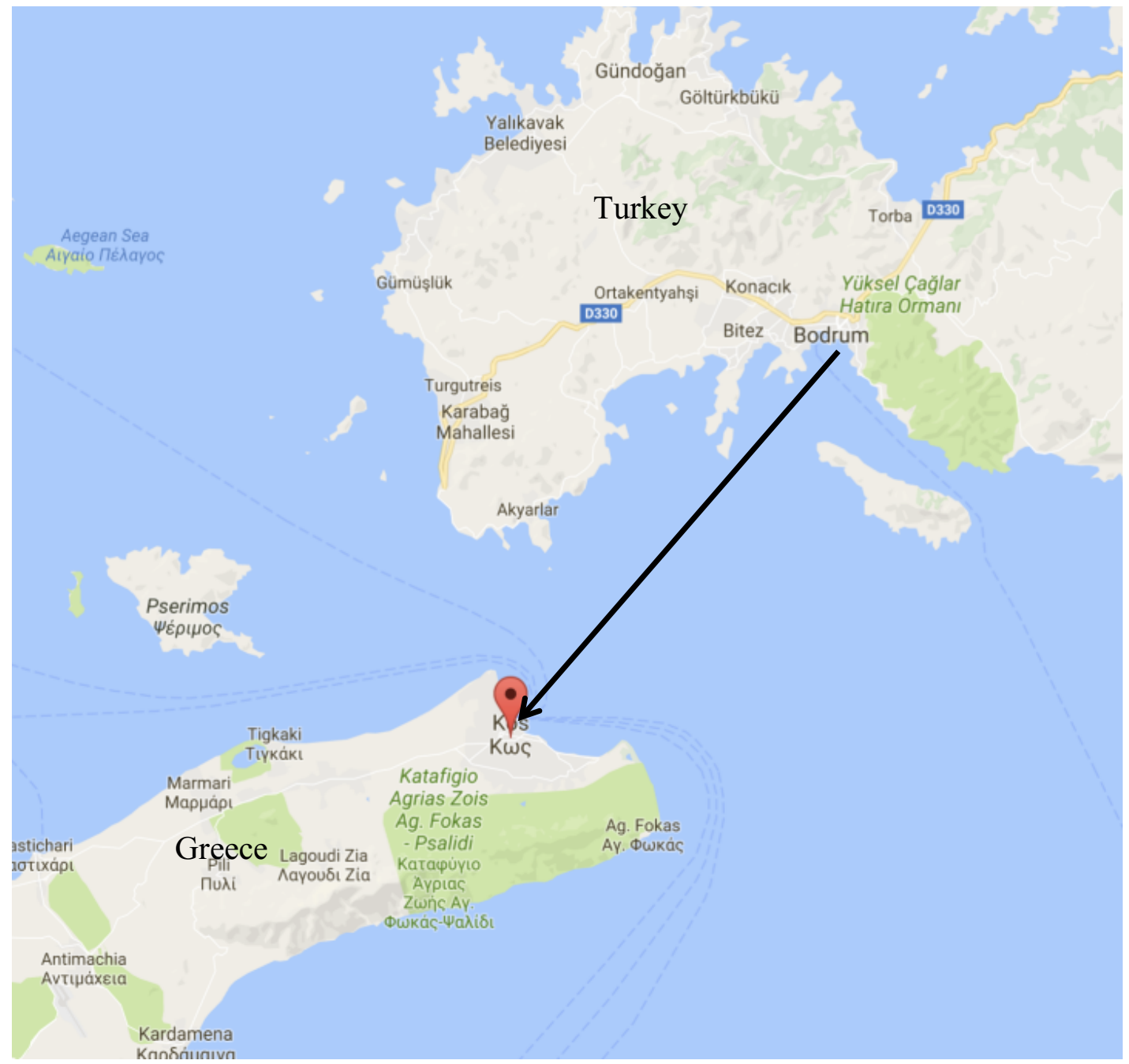

Figure 8: Map of Aylan Kurdi's crossing from Bodrum, Turkey to Kos, Greece across the Aegean sea. 


\subsubsection{Canada's Good Image}

What I have called the "Canada's Good Image" was the second dominant framing of the arrival of Syrian refugees in Canada that I examined. This framing was largely concerned with the optics of Canada accepting (or not accepting) Syrian refugees. In particular, this framing centered on first the acceptance of Syrian refugees as Canada's moral obligation or responsibility, second on a characterization of "progressive" western generosity and values and third on Canada's need to continue a history of much-lauded "exceptional" refugee acceptance.

The first approach under the "Canada's Good Image" frame of the arrival of Syrian refugees in Canada was perhaps the exploration of Canada's moral obligation or responsibility to accept and settle refugees. Smyth (2015) wrote that the acceptance of a larger number of Syria's refugees " "right away" would make us "morally whole" (p. A1), while Denton (2015) noted that in light of Aylan's death that there is "room to consider matters of morality, of conscience, of compassion and simple decency....and the role Canada should play” (p. A1) and Glavin (2015) argued that Canada's acceptance of Syrian refugees would be "decent" and "maybe even slightly grand" (p. A13). These authors draw on words such as "moral wholeness" and "decency" that are connected with Judeo-Christian duty. Reader understanding of these language codes, allow the authors to evoke that sense of Judeo-Christian responsibility and obligation towards Syrian refugees. In this context, I argue that rather than promoting genuine compassion cooperation amongst Canadians and displaced Syrians this charitable sentiment takes on racist overtones by positioning the western country of Canada as the benevolent master and benefactor of a backward and stunted "Oriental” Syrian nation.

Indeed, one article entitled "Syrian refugee crisis; the world needs more Canada" states: "But they came then, as they do today, because life where they were was nasty brutish and worse and Canada represented hope. "Canada," said Sir Wilfred Laurier, "shall be 
the star towards which all men who love progress and freedom shall come." It has always been so.” (2015, p. F9).

A few things are done in this passage that shift the focus of the "Canada's Good Image" frame from Canada's moral obligation or responsibility to a discussion of "progressive" western values. In the first sentence the author directly quotes from Hobbes' Leviathan (1651) and likens Syria to a place without an established social contract or government, where humans exist in a perpetual state of war, where every man lives for himself and where life is "nasty, brutish, and short" (p. 78). This is a completely false claim about life in Syria. Hobbes' social contract theory states that the establishment of bureaucracy is equated with enlightenment and has been critiqued most notably by Mills (1997). Mills (1997) describes how racism underpins the social contract described by Hobbes and cannot be attributed to failings of "imperfect" men. This racial contract is a tacit and at times explicit agreement among the west to assert, promote, and maintain dominance over the East. Said (1978) in his discussion of orientalism notes that countries of the East have long been characterized as backward, useful "in the modern world only because the powerful and up-to-date empires have effectively brought them out of the wretchedness of their decline and turned them into rehabilitated [and] productive colonies" (p. 35). In other words, Said is noting that orientalism hinges on the west's ability to claim a complete and intimate knowledge of the East. By calling life in Syria "nasty, brutish and short" the author of this article suggests that only through the generosity and benevolence of an enlightened western power such as Canada, can the people of Syria, including Syrian refugees, ever amount to or attain anything worthwhile.

The second sentence of the above passage also munifies Canada and the west's "good" image. This phrase "Canada shall be the star towards which all men who love progress and 
freedom" draws on reader knowledge of the world, specifically of Canada's history where between 1840 and 1860, before the American Civil War, enslaved Africans followed the North Star on the Underground Railroad in the United States to find freedom in Canada (CBC, 2001, p. 1). The phrase, which is a quote from then-Prime Minister Sir Wilfred Laurier, is one that draws heavily on the myth of Canada as a gentle and prosperous "Promised Land" for those who seek to escape misery. In reality, Canada in the late 1800s was divided over the settlement of newly arrived black slaves where with "every meeting in favour of abolition, there was another wanting an end to black immigration...[with] some citizens openly demand[ing] slaves be sent back" (CBC, 2015, p. 2). Syrian refugees who are newly arrived in Canada face a much more complex reaction from Canadians than a free and open welcome, and likely will also struggle with a distinct lack of immediate progress or freedom.

The third and final approach under the "Canada's Good Image" frame of the arrival of Syrian refugees in Canada focused on Canada's need to continue a history of "exceptional" refugee acceptance. Phrases such as "we have done it before" (Cukier, 2015, p. A19) and "Canada has the expertise and capacity to do it again" (Showler, 2015, p. C4) or "we're a country that takes in people from other cultures" (Blackwell, 2015, p A6) or "this may be Canada's chance to be 'mentioned in the good books of history' if it opens its doors to Syria" (Sanders, 2015, p. A6) all suggest to readers Canada's importance as a past leader for refugee acceptance and the importance of this trait for the maintenance of Canada's shiny international image.

Additionally, some authors draw directly on historical examples of Canada's acceptance of refugees such as the Vietnamese "boat people" in the late 1970s or the Jewish refugees after the Second World War where they argue that Canada has a "decades' old tradition of openness" 
and assert that "the groundswell of support for resettling Indochinese boat people is as much a part of our history as our infamous "none is too many" policy toward Jewish refugees" (Smith, 2015, p. A19). The discussion of Canada's supposedly glorious history by these authors is similar to that of Canada's progressive and enlightened role as a western power in the previous section. This examination of Canada's history fails to provide more than a superficial rendering of the ugly intricacies of immigration. Only one author notes this discrepancy stating that: "the complexities of the Canadian response to the Indochinese refugee crisis are being lost in favour of a celebratory narrative that uncritically celebrates the history of Canadian immigration" (Madokoro, 2015, p. A4). In sum, the majority of articles that frame the arrival of Syrian refugees in Canada as connected to "Canada's Good Image" and illustrious history do not deal in any real way with the darker aspects of Canada's history of immigration.

\subsubsection{Federal Election Game}

What I have called the "Federal Election Game" was the third dominant framing of the arrival of Syrian refugees in Canada that I examined. This frame placed all discussion of the arrival of Syrian refugees in Canada in the context of the 2015 Canadian Federal Election. This frame functioned primarily by emphasizing the exclusionary nature of the then-current Conservative leadership's immigration policies suggesting that these policies were responsible for Aylan's death. This frame also suggested that the then-imminent Canadian Federal Election was an opportunity to revisit those immigration policies and to re-examine the choice of governmental leadership.

Numerous articles argued that Aylan's photograph prompted a drastic shift in the focus of the 2015 Canadian Federal Election. Smyth (2015) argued that now "everything has changed" (p. A1) with "the government's refugee policy in the spotlight of the federal campaign" (Curry, 2015, p. A6). Articles also noted that the campaign was "knocked off the axes" that the 
photograph "rocked the campaign" (Blanchfield, 2015, p. A11), that the photograph "stopped the Canadian election campaign in its tracks" (Curry, 2015, p. A6) and that there was considerable “damage wreaked on the Conservative campaign" (Herbert, 2015, p. A16). The words used in these statements indicate physical destruction or disturbance and these metaphors demonstrate to readers that the photograph of Aylan Kurdi de-stabilized the 2015 Canadian Federal Election campaign, much as a bowling ball de-stabilizes the pins at the end of the lane. The metaphors used here also suggest to readers that the 2015 Canadian Federal Election campaign is a carefully constructed entity where politicians deliberately craft a particular political position on a wide range of issues.

In fact, many articles scrutinized the then-current Conservative leadership accusing Stephen Harper and his conservative administration of "lacking compassion" (Curry, 2015, p. A6), crying “crocodile tears" over Aylan's death (Jabir, 2015, p. A11), and demonstrating a debilitating "unwillingness to move past talking points" (Hebert, 2015, p. A16) that depicts the "Conservative government as heartless to refugees" (Anonymous, 2015, p. A6). The articles paint Stephen Harper as lacking any real empathy or concern over the death of Aylan and over the lives of Syrian refugees, and imply that his commitment to statecraft and his political image are his only priority. Stephen Harper and his administration were repeatedly denigrated in the articles with one author arguing that:

"We should not be tarred internationally by those who represent us on the global stage Conservative Leader Stephen Harper, whose world is built on dispassionate political ledger sheets that will not be moved by personal tragedy, and his inept immigration minister, Chris Alexander, the thin-skinned, overly combative master of obfuscation and doublespeak.” (Harper, 2015, p. A1). 
This passage draws heavily on personal attacks using words such as "dispassionate", "inept", "thin-skinned" and "overly combative". The strong emotional content of those words vilify both Stephen Harper and Chris Alexander, and offer a definitive negative portrayal of these political leaders. The phrase "obfuscation and doublespeak" has its origins in George Orwell's dystopic novel Nineteen Eighty-Four, which popularized the closely related words "doublethink" and "Newspeak" (Orwell, 1992). Used here this phrase requires readers to draw on their knowledge of the novel to connect Chris Alexander and the omnipresent government that manipulates and tightly controls its populace in Nineteen Eighty-Four (Orwell, 1992). The author is therefore able to use this reference to better illustrate his point about the duplicitous and crafty nature of Stephen Harper and his conservative administration.

Despite the denigration of the Harper Government present in the articles, the majority of articles suggested that the 2015 Canadian Federal Election was ideal for a re-examination of Canada's immigration policies. Authors mentioned that the hope that "the horrific photograph of three-year-old Alan spurs people and governments into action" (Kennedy, 2015, p. A15) and that the photograph has the "potential to be a turning point" (Ivision, 2015, p. A4) with an innate "ability to turn Canadians from observers of events to participants - in a way that other political stories in this campaign have not" (Delacourt, 2015, p. IN2). However some articles argued that shifting the focus to the Federal Election in the light of the death of Aylan Kurdi and his family was at best unpalatable and at worst a deliberate and shameful manipulation of events by all political parties (not just the Conservative administration) to advance political goals and boost election ratings. Authors insisted that "all of the major federal parties will no doubt use this tragic image of death to further their own political campaigns" (Losier, 2015, p. A19) and that "you'd never know, in the welter of these competing plans and pledges, that all of the parties 
were promising more or less the same thing" in terms of the acceptance of Syrian refugees ("We Can Do More", 2015, p. A8).

One author commented on this contradictory manipulation of Aylan's death stating: “...there's an election on and points to score. And after the opposition and their online acolytes had finished playing politics with the issue, Conservative supporters rushed in to play politics all over again, this time over the playing of politics. How could you have used that poor little child for partisan purposes, they demanded to know, for all the world as if they were not putting the same dead child to the same use.” (Coyne, 2015, p. A16).

This passage highlights that politics are a "game" to be "played" or even a frivolous competition with "points to score" and not a serious or considered endeavor. The comment that there is a "playing of politics...over the playing of politics" highlights that all political parties, not only the Conservatives, have made use of Aylan's photograph and his death, as well as the death of Aylan's family and other Syrian refugees to highlight various campaign pledges as well as to besmirch the political opposition. The comment that political parties were "using" Aylan's death highlights concerns over the racist nature of the approach taken towards Aylan's death. As mentioned in several articles, all political parties claimed to know what could have prevented Aylan's death or what might prevent the death of other refugees like Aylan. Articles mentioned everything from "admit[ing] more Syrian refugees immediately" (Curry, 2015, p. A6) or "the importance of military action against the Islamic State” (Radwanski, 2015, p. A9). This claimed knowledge of what would be best for Syrian refugees is similar to how Said (1978) explains that orientalist knowledge is produced. Said (1978) argues that orientalist knowledge is produced when the west asserts its claim on an intimate and total knowledge of the East and thus inaccurately represents the needs of the Middle East. The above passage clearly indicates that 
Aylan's photograph and death furnishes evidence for presumed knowledge about international migration and refugee policy or need for Canadian military intervention in the Middle East.

It must be noted here that despite the fact that thousands of refugees from Syria have drowned, Aylan's drowning is the only one that has received attention and coverage from the Canadian media. Indeed in the first week of January of 2016, over 100 refugees drowned crossing the Mediterranean Sea. In total, over 2500 refugees drowned in 2016 (A1 Jazeera 2016, Sputnik 2016). The Canadian news media has created the seemingly inescapable connection between Aylan's death and poorly implemented federal policy. The call to action against such atrocities coincides suspiciously with the 2015 Federal Election, despite the high numbers of Syrian refugees who drowned in 2014 and earlier in 2015.

\subsubsection{Canada Can Profit from Refugees}

What I have called the "Canada Can Profit from Refugees" frame was the third dominant framing of the arrival of Syrian refugees in Canada that I examined. This frame placed all discussion of the arrival of Syrian refugees in Canada in the context of their future potential economic contributions to Canada. Emphasis was placed on refugees being economic assets and their future contributions to a competitive economy were highlighted. Sanders (2015) wrote that:

"Canada, which relies on immigration for population growth, would benefit...We need people to help us drive our economy...Syrian newcomers would be a good fit for Canada...English is taught as a second language in Syria and a lot of families are highly educated and highly skilled and will contribute to society. We're talking about very hardworking people...Helping them resettle here would be a good investment....It will cost some money but once the families come here and establish themselves, they become taxpayers and part of the Canadian mosaic." (p.A1)

Her use of the words "benefit", "drive our economy", "contribute to society", "investment" and 
"taxpayers" evoke financial management. The suggestion here is clearly that the acceptance of Syrian refugees into Canada would increase Canada's wealth. Additionally, Sanders' discussion of the "highly educated and highly skilled" and "hard-working" Syrian refugees suggests that Canada is reluctant to accept any refugees except those that are institutionally high achieving with a strong work ethic. The focus has shifted away from the desires for migration of Syrian refugees themselves or even the global need for the resettlement of the displaced population of Syrian refugees and is now centered on the possibility of economic gain for Canada. Readers are made to understand that Syrian refugees will arrive and make Canada a richer country. Other authors continued along this vein noting that Canada takes in immigrants with "much benefit" (Bramham, 2015, p. A6), immigrants who may "fulfill their potential - perhaps becoming scholars or doctors or inventors" (“An unfair outcome", 2015, p. A22), and who will ultimately "pay it forward" (Cukier, p. A19) to other Canadians. In evidence here is the understanding that an immigrant's value is entirely economic.

Sanders' final phrase, "Canadian mosaic", is a reference to a term adopted by Statistics Canada in the 2001 Census to describe the varied assortment of immigrants, cultural practices and languages spoken by the inhabitants of Canada. This term drew in many ways from the policy of multiculturalism first adopted by Pierre Elliot Trudeau's government in the 1970s and 1980s (Kobayashi,1983, p. 205). Though heavily critiqued (Thobani 2007, Mackey 1999), the concept of the cultural mosaic is firmly entrenched in the Canadian psyche and connected to Trudeau's nationalist project of multiculturalism. With this reference to the cultural mosaic readers thus understand the acceptance of refugees and immigrants into Canada, including Syrian refugees in Canada to be a point of pride and as enabling, according to Thobani (2007) "the nation's self-presentation on the global stage as urbane, cosmopolitan, and at the cutting edge of 
promoting racial and ethnic tolerance among western nations" (p. 144).

Sanders's (2015) comment on the "good fit" of English-speaking Syrian refugees is also important to note. This comment suggests that those Syrian refugees who don't conform to the homogenous standard of a Canadian; who aren't English speaking and culturally similar to this mythical "average Canadian", will not prosper or be welcomed into the country. Although Sanders' text (2015) demonstrates an attempt to highlight the positive aspects of accepting Syrian refugees, the emphasis on the economic benefits and on the supposed ease with which Syrian refugees will "fit in" suggests that Sanders is pandering to a reader predisposed to exclude Syrian refugees due to a racist understanding of them as exotic and unpalatable foreigners. Indeed, this sentiment is echoed in an article by Kilford (2015) who argues outright that the "vast majority [of Syrian refugees] will not become burdens" (p. B6). The statement indicates that there exists a common assumption among Canadians that refugees are generally detrimental to the smooth functioning of a prosperous country. This idea of "fitness" is further addressed in the following framing that will be discussed.

\subsubsection{Refugees are Unwanted}

The previous framing of Syrian refugees as profitable has much in common with the fifth framing of the arrival of Syrian refugees in Canada that I examined. In this framing authors fall primarily into two camps: one group of authors and articles assert that the preservation of the integrity of Canada's borders is paramount and that "bogus" or "undeserving" refugees must be excluded and the second group of authors and articles argue that this exclusionary stance is not only unfounded but also deeply racist and prejudiced. As in the previous framing, a discussion of refugees that are "fit" to enter Canada is central, but this time the focus shifts from those refugees who are "profitable" and "hard-working" to a discussion of refugees who are "deserving". 
Authors Smyth (2015) and Ivision (2015) argue for the exclusion of refugees that cannot prove they are "genuine refugees" and who may be "bogus claimants". Indeed, Ivision (2015) asserts that:

"Few Canadians would want us to return to a system that was abused, not by the huddled masses from war zones, but by Mexicans, Hungarians and Czechs seeking a higher standard of living." (p. A4).

The use of the word "abused" by the Ivision (2015) in the above text indicates to readers that there are claims that deserve the attention of the Canadian government and those that do not due to the counterfeit nature of their need. This is similar to the myth of the Welfare Queen propagated by President Richard Nixon to justify decreased Federal spending on social support programs in lower income and predominantly racialized communities (Hancock, 2004). Hancock (2004) suggests the term "politics of disgust" to denote how a racist and prejudiced rhetoric about a marginalized and racialized group was used to curtail and limit discussion about issues pertaining to and affecting that group. Ivision's (2015) claim that some people or groups of people should be inherently ineligible to immigrate to Canada, due to a lower level of suffering than those "huddled masses from war zones" suggests how prevalent stereotypes and politically motivated misperceptions about race, class, and gender can be used to instigate a "politics of disgust" and limit discussion on the topic of immigration. Once again, Said's concept of orientalism as claimed knowledge of the "other" surfaces (1978). By describing claimants who are "seeking a higher standard of living" as "bogus", Ivision claims to understand the needs and motivations of refugees and immigrants coming to Canada. Readers are thus presented with a white western orientalist knowledge claim over the perceived desires and motivations of those in the East. 
In the second group of articles, authors attempt to highlight that racism and prejudice towards Syrian refugees have become the social norm by stating that "refugee-bashing rhetoric, maneuvering to deny and decrease protection and ramped-up efforts to detain and deport asylumseekers" (Jabir, 2015, p. A11). Authors note that the title of "deserving" refugee has increasingly and unjustly gone to refugees from the Middle East who are part of a group of "religious minorities" (i.e. Christians) rather than assessing refugees on a basis of need (Elghaway, 2015, p. F2). Championing non-Muslim Syrian refugees over the supposedly less-deserving and larger population of Muslim Syrian refugees is blatant and appalling discrimination. Author Kilford (2015) also touches on what Syrian refugees "deserve" when she mentions the newspaper comment sections where there was a deliberate exclusion and repudiation of Muslim refugees by reader commenters. These reader commenters feel that accepting Syrian refugees is unnecessary and undesirable as it is not Canada's issue. Kilford (2015) argues:

“...those commenters conveniently ignore the fact that when your government sends CF18 fighter jets to supposedly "liberate" the Libyan people and actively works to undermine the Syrian government, it is your issue.” (p. B6).

The caustic tone of this text is produced by the words "conveniently ignore", "supposedly" and the quotation marks around "liberate". This sarcasm serves to emphasize the contradiction held by readers and Canadians who support the war waged by Canada and its allies in and on Syria but refuse to consider the consequential large displaced population of Syrian refugees. Kilford (2015) thus argues that Canada must accept Syrian refugees as our "Middle Eastern meddling" has created their condition (p. B6).

\subsubsection{Canada is a Safe Space}

In this section I will briefly touch on the final framing of the arrival of Syrian refugees in Canada by investigating the concept of Canada as a desirable and "safe space". This framing is 
arguably the most central to the orientalist understanding of the Middle East and Syria by the west, as it claims that the west is an ideal and bucolic paradise in which all non-westerners aspire to live. Although this framing shares much with the "Canada's Good Image" frame, I argue that it is different as it is concerned not with perceptions of Canada's goodness or utopic nature, but with imbibing Canada with superior virtues and qualities. Authors and texts that frame the arrival of Syrian refugees in this way describe life in Canada as a "refuge" (Eagland, 2015, p. A1), as a "better life" (Hopper, 2015, p. A11), as a "land of opportunity" as a "beacon of light" and as a "safe haven" (Kilford, 2015, p. B6). These words all have connotations of hope and an almost mythical quality reminiscent of that of the biblical Promised Land. Several authors relied on the metaphor of dryness to describe the safety of Canada in comparison with refugee countries of origin. Gormley (2015) describes the migrant lament that "western countries won't bring them to dry land safely" (p. A17) and in the article "An unfair outcome" (2015) the author mourns the fact that if Aylan and Ghalib Kurdi had been "plucked from a rising tide of desperate migrants and found their way to a full life in Canada" they may never have drowned (p. A22). This metaphor of dryness as safety stems from Aylan's death from drowning and serves to remind the reader of this terrible death. Readers are expected to be moved to sympathy, and see the arrival of Syrian refugees to the "dry land" in Canada as the only respite from their situation.

By comparing Canada and the west to paradise, authors paint the East and specifically Syria as a hellish and dangerous place, where life is precarious. By maintaining that the west is the only source for preventing the death of Syrian refugees, authors of texts that frame the arrival of Syrian refugees in this way are propagating the notion that western exceptionalism is to be celebrated, that the situational context can be ignored in favor of stereotypical assumptions and that other cultures can be regarded with derisive contempt (Said, 1978, p. xxvii). Reliance on 
misinformation about Syria and Syrian refugees, along with the intense energy expended on the examination and study of the Middle East to produce conclusive data about the East and its people is a form of neo-orientalism (Said, 1978). In the following section I will examine the framings of the departure of Syrian refugees from Syria.

\subsection{Departure of Syrian Refugees from Syria}

\subsubsection{Brutal Regime in Syria}

What I have called the "Brutal Regime in Syria" was the predominant framing of the departure of Syrian refugees from Syria. This framing was accomplished in three major ways, all of which attributed the "Brutal Regime in Syria" to a different cause. The first approach for this frame was to blame ISIL/ISIS for the conditions in Syria, the second was to blame Syrian President Bashar al Assad, and the third was to blame the so-called "Civil War" in Syria. In this section, I aim to unpack each of these approaches to "Brutal Regime in Syria" frame in order to better understand how the Canadian news media contributes and sustains a campaign dedicated to disinformation and misinformation about the circumstances of the departure of Syrian refugees from Syria.

The majority of articles that framed the departure of Syrian refugees from Syria as departing from the "Brutal Regime in Syria" did this by assigning blame and generally vilifying ISIL/ISIS. Authors wrote that ISIL/ISIS were "psychotic jihadists killing people in Syria" (Smyth, 2015, p. A1), that ISIL/ISIS had contributed to "destruction and chaos" (Blatchford, 2015, p. A18), that ISIL/ISIS needed to be prevented from "killing tens of millions of people" (Kennedy, 2015, p. A13) and that ISIL/ISIS had been "putting out a whole album of absolute barbarity" (Murphy, 2015, p. A16), all of which were causing Syrians to depart with haste from Syria. The exaggeration in the last two statements is almost comical. Though there is little agreement on the total number of deaths (civilian, military, foreigner...etc.) due to the War in 
Syria, the majority of estimates do not exceed 400,000, with Sputnik News estimating around 228,000 (Sputnik News, 2016, p. 1). Additionally, the idea that ISIS is predominantly responsible for civilian deaths is incorrect with only around 2500 civilian deaths attributed to ISIL/ISIS (Sputnik News, 2016, p. 1).

The caricature of ISIL/ISIS as a group of "psychotic jihadists" also bears closer examination. With no discussion of the creation of ISIS, who trained and armed and supports ISIS, with no attempt to even examine the group, its habits or its members, or even why it draws followers both nationally and internationally on such a large scale (Sputnik News, 2015, p. 2), the caricature is unsupported and yet allowed to languish as part of the misinformation campaign perpetuated by the western news media. As Said (1978) argues, within modern orientalism the Arab is presented in a large group, with no individualizing characteristics and consistently held responsible for the misery and senseless rage inflicted on the west with the ever-present "menace of jihad" lurking in the background (p. 287). Thus the Arab is always negatively portrayed with "virulent anti-Islamic politics that have remained unchanged since the Middle Ages and Renaissance" (Said, 1978, p. 287). Whatever part ISIL/ISIS is playing in the War in Syria, the complete renunciation of the need to even discuss or explore their development and evolution of their group is a neo-orientalist practice.

Some articles, taking the blame ISIL/ISIS approach, discuss the persecution of Christians by ISIL/ISIS that is occurring in Syria. Sheridan (2015) reports that:

"Christians in cities where ISIS is present are not allowed to pray in public or where someone might hear them pray. They are also forbidden from displaying religious symbols or building churches."

The focus here on the persecution of the Christian minority in Syria, is clearly intended to tug at 
the heartstrings of a predominantly Christian Canadian public. That the forbidding of public Christian worship is the great crime (among many crimes) committed by ISIL/ISIS, is a way of humanizing the otherwise unpalatable non-Christian and Islamic Arab Syrians. Readers are encouraged to think here that the Arab, the ISIL/ISIS “jihadist”, exists here only as a negative value, a “disrupter of Israel's and the west's existence” especially when Judeo-Christian legacies of power and domination are disturbed (Said, 1978, p. 286). Although it is clear that ISIL/ISIS is responsible for the destruction of much of Syria's infrastructure, of killing, maiming and of targeting not only Christians but also Muslims and their respective places of worship the pertinent question is how, why and who trained, supported and invented ISIL/ISIS?

The second approach for the "Brutal Regime in Syria" frame was to blame Syrian President Bashar al Assad for the conditions that necessitated the immediate departure of Syrian refugees from Syria. Authors claim that Syrian refugees are killed by the "indiscriminate weapons of Syrian President Bashar al-Assad" (Potter, 2015, p. A1), are under "Bashar Assad's brutal assault" (Yogaretnam, 2015, p. A4) and "his special brand of genocide" (Blatchford, 2015, p. A14). With articles that take this approach, there is the overwhelming sense that Syrian President Bashar al Assad should be held entirely responsible for the death of Syrian refugees. There also seems to be a particular fixation on the barrel bombs supposedly dropped by Bashar al Assad on his own population. With Potter (2015) arguing that "illegal barrel bombs dropped on residential areas by regime helicopters" will be predominantly responsible for the death of Syrian refugee children and that "no serious analyst of the Syrian civil war believes otherwise" (p. A1). Potter makes these statements as if they are fact, when Sputnik News (2015) argues that it was actually Saudi Arabian army helicopters that dropped barrel bombs carrying chlorine gas on Syrian civilians in late 2015. The phrase "no serious analyst" indicates to readers that if you 
don't share Potter's opinion, you are a mere amateur incapable of assessing the information in the correct (read: the same) way. Once again, this refusal to even present information that does not confirm the prevalent anti-Islamic bias is part of the active disinformation of the Canadian population.

Another important facet of the blame Syrian President Bashar al Assad approach to the "Brutal Regime in Syria" framing of the departure of Syrian refugees is the constant juxtaposition of the brutality of ISIL/ISIS and that of the Syrian President Bashar al Assad. Authors continually place Syrian refugees as doubly disadvantaged and "squeezed” ("Syrian Refugee Crisis", 2015, p. A10) between President Bashar al Assad's “brutal assault" and the “destabilizing effect” of ISIL/ISIS (Yogaretnam, 2015, p A4), or as caught between "ISIL on the one hand, and the Syrian dictatorship of Bashar al-Assad on the other" who are both capable and responsible for "barbarous attacks" ("We Can do More", 2015, p. A8). Describing the War in Syria as one fought between two sides with refugees dying in the middle, is grossly erroneous. Inelegant and incorrect generalizations are being made about President Bashar al Assad, ISIL/ISIS and about Syrian refugees. President Bashar al Assad is the elected representative of the Syrian people (some of whom may not support him, but a majority of whom do), and is not a "dictator". ISIL/ISIS is a multi-faceted organization that cannot be said to be the sole opponent of President Bashar al Assad. Syrian refugees are members of various fighting groups, peacekeeping and humanitarian coalitions both Syrian and international, some refugees may be Kurdish, some refugees may be supporters of President Bashar al Assad's government, or some refugees may be members of ISIL/ISIS and on and on. Syrian refugees are thus far from the homogenous and faceless group of victimized Arabs to which they are unscrupulously assigned. But perhaps most glaring of the errors in describing the War in Syria as bilateral in nature is that 
no mention is made of the role that foreign governments and powers are playing by participating in and exacerbating the War in Syria. As I argue in the following chapter, the west has actually had quite an active role in the War in Syria as they have created, trained and armed a variety of opposition factions. Indeed, the west largely escapes all blame in the "Brutal Regime in Syria" framing of the departure of Syrian refugees from Syria.

The third approach for the "Brutal Regime in Syria" frame was to blame the so-called "Civil War" in Syria. Authors argue that Syrian refugees are fleeing a multi-year, horrendous, catastrophic horrific and horrible "civil war" ("An Unfair Outcome”, 2015, p. A22 \& "Syrian Refugee Crisis", 2015, p. A10 \& DiManno, 2015, p. A2 \& Howlett, 2015, p. A11 \& Hebert, 2015, p. A16 \& Mason, 2015, p. S1 \& Woelfel, 2015, p. C4). I argued previously that the use of the term "Civil War" is a euphemism to mask the unwieldy multi-state and multi-group proxy war being fought by western and eastern powers in Syria. Calling the War in Syria a "Civil War" also curbs any mention of the role of the west in the War in Syria. Readers are made to understand the War in Syria, through the description of the bilateral nature of the war as described above and with the elimination of the discussion of other involved parties, as an internal matter. This perspective removes the west from the actual war and contributes to the framing of the departure of Syrian refugees from Syria as due to the "Brutal Regime in Syria".

Only one article discussed the west as having any part in causing the War in Syria. Kilford (2015) states:

"Four years ago, and using UN Security Council Resolution 1973 as a cover, many of these European countries as well as Canada, toppled the Libyan government. When the Syrian uprising began in early 2011, the British, French and Canadian governments, among others, also moved to quickly isolate and weaken the Assad regime. But there was 
little consideration as to what this could mean for the Syrian people. Well, now we know." (p. B6)

Kilford's article stands alone in its examination of the role of the west in the War in Syria of the 168 newspaper articles I examined. It alone combats the misinformation produced on the role of Canada and the west in the War in Syria. Kilford's article is the only article that explicitly mentions the multi-national military coalition and the damage caused by the allied western members of the coalition, along with the notion that there was little regard for the consequences of pursuing such a military goal. Kilford's article stands alone in its attempts to disturb the calcified mythologies that explain the power relations between the East and west. The key feature of orientalism according to Said (1978), (which I argue is most evident in this final framing - although it is evident in all framings thus far discussed), is that orientalism relies on a "flexible positional superiority, which puts the westerner in a whole series of possible relationships with the Orient without ever losing him the relative upper hand" (p. 7). Thus in the telling of the stories about the Middle East, about Syria and about Syrian refugees; the West, Canada and Canadians never fail to hold the higher ground and all attempts at depicting the foreigner, despite their various forms and approaches never waver in the positioning of the west as superior to a woefully inferior East. In the following chapter I turn to a deeper discussion of the three elements discussed in the "Brutal Regime in Syria" framing. Building on aspects of Chapter 2 I expand somewhat on the creation of ISIL/ISIS, the supposed "brutality" of President Bashar al Assad, and on the idea of the War in Syria as a so-called "Civil War". Throughout this I examine the direct and indirect role of the west and the western media in the War in Syria. 


\section{Chapter: Further Discussion}

In this chapter I will examine in more detail the three aspects of the "Brutal Regime in Syria" framing. Building on aspects of Chapter 2 I expand somewhat on the creation of ISIL/ISIS, the supposed "brutality" of President Bashar al Assad, and on the idea of the War in Syria as a so-called "Civil War". I will address how, why, who trained, supported and invented ISIL/ISIS; also discussing the role of regional countries (Saudi Arabia, Qatar, Turkey) and the billions of dollars of support to fundamentalist extremist groups such as ISIL/ISIS. I will also examine what makes Assad's regime "brutal" and the "proof" that his is a "brutal regime". Finally I will discuss why the War in Syria has come to be called a "civil war". To do all this I emphasize the direct and indirect role of the west and the western media in the War in Syria. This merited a chapter all to itself as it is the cornerstone of my commitment to challenge orientalism and imperialism which is, as previously stated, the major implication of my research.

Early in 2015 it was reported by Hakem al-Zameli, head of the Iraqi Parliament's National Security and Defence Committee, that the committee has access to the photos of coalition planes (specifically British and American) that were shot down while they were carrying weapons to ISIL/ISIS (FARS News 2015, cited in Motroc, 2015). Hakem al-Zameli also stated that the Iraqi parliament has asked London and Washington for explanations, mentioning daily reports from people and security forces in the al-Anbar province on numerous flights by the US-led coalition planes that airdrop weapons and supplies for ISIL/ISIS in terrorist-held areas (FARS News 2015, cited in Motroc, 2015). The news that the United States would willingly supply terrorist groups was met with shock and denial in western countries with the United States State Department denying media reports that the Jabhat Fateh al-Sham (previously known 
as the Al-Nusra Front) terrorist group received weapons from Washington or that weapons were intentionally air-dropped in ISIL/ISIS held areas (FARS News 2015, cited in Motroc, 2015).

However, Russia's envoy to the UN Vitaly Churkin said, speaking at the Security Council that the Jabhat Fateh al-Sham in Aleppo still continues to receive military hardware from its Western backers. Churkin stated:

“They are armed by tanks, APCs, field artillery, multiple rocket launchers... dozens and dozens of units, including heavy weaponry... Of course, they couldn't have made this equipment themselves. All of this has been received by them and is still being shipped to them by generous Western backers, with the US, presumably, turning a blind eye" (Kelly, 2015).

Yemeni leader Ansar Allah stated: "Wherever there is U.S. interference, there is al Qaeda and ISIS. It's to their advantage" (al-Bukaiti, 2015 cited in Anderson, 2016). Ansar Allah continued stating that the United States prefers the chaotic situation in the province because it does not want the ISIL/ISIS fight to come to an end (al-Bukaiti, 2015 cited in Anderson, 2016). The existence of such terrorist groups is key to sustaining the the myth of the patriotic and unflagging western fight against terrorism which helps to justify western involvement abroad and camouflages various political and economic interests. This myth remains a key element of the western psyche and political landscape (Blum, 2004). Indeed, Anderson (2016) argues that Washington maintains two closely linked myths with regards to terrorist organizations such as ISIL/ISIS in the Middle East and Syria. The first myth is that, from 2014, the US became engaged in a war against extremist terrorists, in both Iraq and Syria. This followed several years of trying to topple the Syrian Government by backing armed groups, which it calls "moderate" (Anderson, 2016). Through this myth the US claims to be playing a protective role for the benefit 
of the peoples of the region. The second myth is that there is a significant difference between the "moderate rebels" the US arms, finances and trains, and the extremist terrorists (such as ISIL/ISIS) it claims to be fighting (Anderson, 2016).

These two myths support a shift in the rationale for the War in Syria from one of "humanitarian intervention" to a revival of the Bush era "war on terror". The "fall back" story, advanced by some of Washington's domestic critics, is that United States' practice in the region has created a climate of resentment amongst orthodox Sunni Muslim communities, and the extremist groups emerged as a type of "organic reaction" from those communities to repeated United States' interventions. This story hides the more damaging conclusion that the United States and its coalition allies like Britain, Canada and Turkey directly created the extremist groups (Nicks, 2014, Anderson, 2016). As seen above, the Canadian news media I examined presents a thoroughly one sided portrait of ISIL/ISIS and other terrorist groups. Whatever part ISIL/ISIS is playing in the War in Syria, the complete renunciation of the need to discuss or explore the inceptions of the group is a neo-orientalist practice conducted primarily by western countries to obscure their central role.

In addition to the role played by the United States and its coalition allies such as Turkey, other Middle Eastern countries like Saudi Arabia and Qatar (who are allies with the United States and its coalition that includes Canada, have contributed to the creation, training and funding of terrorist groups such as ISIL/ISIS. Several senior American officials have admitted that their main regional allies have financed ISIS. In September 2014 General Martin Dempsey, head of the US military, told a Congressional hearing "I know major Arab allies who fund [ISIS]" (Rothman, 2014). Senator Lindsey Graham, of the Armed Services Committee, responded with a justification, “They fund them because the Free Syrian Army couldn't fight 
[Syrian President] Assad, they were trying to beat Assad" (Rothman, 2014). The next month, US Vice President Joe Biden went a step further, explaining that Turkey, Qatar, the UAE and Saudi Arabia "were so determined to take down Assad ... they poured hundreds of millions of dollars and tens, thousands of tons of weapons into anyone who would fight against Assad ... [including] al-Nusra and al Qaeda and extremist elements of jihadis coming from other parts of the world ... [and then] this outfit called ISIL" (RT 2014; Usher 2014). Once again, these were consistent and credible admissions, except that Biden sought to exempt the US from this operation by blaming key allies. As Anderson (2016) states the Saudis are politically dependent on Washington and would be unable to mount a major initiative without United States approval. Not only that, the United States systematically controls, by purchase contract and re-export license, the use and sale of its weapons (Export.Gov 2015).

Journalist Eva Bartlett notes that the news media in Canada and the west, not only obscures the role of western powers in creating, training and funding terrorist groups in the Middle East, but also reports sparingly on the atrocities committed by these groups. Bartlett (2014) goes so far as to say that the atrocities of terrorist groups such as ISIL/ISIS are reported only when they might prove "useful" to furthering either the "humanitarian intervention" or the "war on terror" myth. Bartlett (2014) notes that western media has inundated us with news of the filmed beheadings of two American journalists but has not presented information on nonWestern journalists and civilians mutilated and murdered by ISIS, Jabhat Fatah al Sham (formerly known as the al-Nusra front), and associated terrorists in Syria. Bartlett contends that in Syria, there are "thousands of civilians and Syrian soldiers who have been beheaded... by the so-called "moderate" Free Syrian Army (FSA), al-Nusra, Da'esh (ISIS), and hordes of other Western-backed mercenaries" (p. 2). Bartlett recounts her experiences working in Syria during 
the war and interviewing Syrians about the "tens of thousands of civilians [that] have been assassinated and subjected to various sadistic practices - torture, mutilation, crucifixion, burning in ovens, throwing into wells" at the hands of "NATO-gangs" (Bartlett, 2014, p. 2). The convenience and ease with which the western news media lifts and discards stories of terrorist brutality in Syria should enrage, Bartlett argues, as should the fact that the western news media ultimately only emphasizes those stories that "serve the West's stated agenda to overthrow President Assad [or] to dismember Syria” politically (Bartlett, 2014, p. 3).

From a discussion of the role of the west in the creation, training and funding of ISIL/ISIS and the complicity of the media that hides the role of the west and sustains certain myths, I now turn to a discussion of Syrian President Bashar al Assad and his supposed "brutality". As discussed above, the sudden reversal between the "humanitarian" and "war on terror" pretexts for western intervention in Syria has been abrupt. Initially, the western media and governmental representatives denigrated President Bashar al Assad's assertion that he was fighting foreign backed terrorists but now the United States (and its coalition allies like Canada) claim to be leading the fight against those same terrorists. This shift has caused the need to reinforce the western caricature of President Bashar al Assad as the "brutal" dictator by obscuring his existence as a popular and urbane figure within Syria (Anderson, 2014). While I referenced and discussed two instances of the western media's misrepresentation of President Bashar al Assad in Chapter 2: the May 25 2012 Houla Massacre and the chemical weapons attack near Damascus August 21 2013 (Anderson 2016, Hersh 2014), in this section I examine two additional instances.

The central problem with this portrayal is President Bashar al Assad's great popularity in Syria, a popularity that is clearly at odds with his image of "brutal dictator". His strong win in 
Syria's first multi-candidate elections in June of 2014 is a testament to that fact. As Williams is quoted as saying in Bartlett (2016):

"Self-determination for oppressed people is absolutely vital. For the people of Syria to determine, very specifically, who they support and how to move forward is crucial. With the elections in Egypt, the US has supported a government which has no popular support, they can't even get people to vote, they can't even pay people to vote. Syrians all over the world [were] dying to vote in this election. We see that as a defiant and courageous act."

The accusations that the elections were rigged are neither accurate nor constructive. The importance for the west to sustain and promote democratic ideals in Syria, rather than destruction in Syria was echoed by Bello in Bartlett (2014). Despite the fact that President Bashar al Assad's political opposition and their Western allies denounced the election as a farce, with U.S. Secretary of State John Kerry calling it a "great big zero" (Aji, 2014); huge numbers of Syrians flocked to support and participate in the 2014 elections (Bartlett, 2014). The election occurred at a time when the Syrian government was at the height of its popularity, with Syrians voting in government held areas (at home) and at various embassies (abroad) such as the one in Beirut where "the masses opted to walk the remaining few kilometers rather than sit in a traffic jam generated by the tens of thousands flocking to vote" (Bartlett, 2014, p.1). According to Syria's parliamentary speaker, Jihad Laham, President Bashar al Assad garnered 10,319,723 votes, or 88.7 per cent (Aji, 2014). The Syrian Supreme Constitutional Court put voter turnout at 73.42 per cent (Aji, 2014). Larudee in Bartlett (2014) argued that although it is possible that the election in Syria was not fully free, fair or open it was probably more free, fair and open than the ones in the United States or Canada. 
Another instance of Western fabrication that caricatures President Bashar al Assad's government as a "brutal" regime is the discussion of the Syrian Army. Numerous articles, including many of the ones I analyzed in this thesis, describe the official Syrian Army as "Assad loyalists" or "regime forces" rather than stating that the Syrian Army is "a large, dedicated national army, with broad popular support” Anderson was quoted as saying in (Sputnik News, 2015). Contrary to the western news media narrative, the Syrian Army has much popular support. Furthermore, many Syrians displaced by War in Syria have not departed from Syria but moved to other parts of it under army protection, something they would be unlikely to do if the army itself was not a functional and protective organization for civilians, as Steele writes "the image of peaceful protests brutally suppressed by army and police is false" (Steele, 2012). Indeed recently, Tima Kurdi, the Canadian aunt of Aylan Kurdi stated that although the western media reports that President Bashar al Assad kills his own people, this sounds absurd to the Syrians since President Bashar al Assad's presidency depends on his ability to retain the support of his citizens (RT, 2017).

From a discussion of the Syrian President Bashar al Assad and his supposed "brutality" I now turn how the proxy War in Syria came to be called a "Civil War", while continuing to underscore the complicity of the western media. As discussed above, the War in Syria is a proxy war, not a civil war. Calling the War in Syria a civil war implies that it is a conflict between and only between - two intrastate parties. In actuality, the War in Syria is due in large part to competing external supporters that use local proxies as part of a larger global struggle. As Estrin and Shapiro (2014) state: "as long as outsiders can access the theater, insurgents eager to fight usually have little difficultly linking up with external supporters willing to supply them with funds and weapons" (p. 2). This is very much the case in Syria, with external supporters 
supplying weapons, money, training and military intelligence to various foreign and domestic terrorist groups. The very large scale participation of foreign jihadists, particularly from 2012 onwards, from a range of countries including Saudi Arabia, Libya, Tunisia, Yemen, Iraq, Chechnya (Russian Federation), Pakistan and various parts of Europe (Komireddi, 2012, Gertz, 2013, Kern, 2013, cited in Anderson, 2016) emphasize the fact that the War in Syria is not a "civil war". Terrorist forces within Syria were able to prolong their attacks because of the participation of thousands of outside fighters, most often paid by Qatar and Saudi Arabia and trained in Jordan and Turkey (Draitser, 2013, cited in Anderson, 2016). Indeed, the Syrian Islamists had been defeated in early 2012 by the President Bashar al Assad and the Syrian Army; but were reinforced by many thousands of foreign jihadists as well as by funding, training and military supplies provided by the west.

The idea of a Syrian "civil war" was sustained and supported by the United States, Britain, France and Canada who at first led a diplomatic offensive, attempting to isolate the Syrian government and to impose successive non-elected exile groups as the "legitimate representatives" of the Syrian people (Barkan, 2013, cited in Anderson, 2016). In concert with regional collaborators particularly Turkey, Qatar and Saudi Arabia, these western countries provided funds, arms and training to various terrorist groups, maintaining all the while that these groups were merely oppressed "resistance" groups within Syria who were struggling against the draconian regime of President Bashar al Assad (Anderson, 2016). Upon the entry of Israel into the conflict, in 2013 when the state carried out several missile attacks on Syria and provided medical assistance to Islamist fighters it was clear that Israel also supported the overthrow of President Bashar al Assad (Gordon, 2013, cited in Anderson, 2016). 
Describing the War in Syria as a "civil war" is central to the "humanitarian intervention" myth discussed above. Proxy wars with claimed missionary or humanitarian aims sustain and promote the myths essential to making those wars more marketable in western countries. Examples of this stretch to Former First Lady Laura Bush's advocacy on behalf of Afghani women to promote the continuation of the war between the United States and Afghanistan in 2001 (Ahmed, 2016). The "tidy moral justification" for its invasion of Afganistan was provided to the United States by Former First Lady Laura Bush's presentation and discussion of the plight of women under the Taliban regime (Gettelman, 2007). This marketing tactic is a relatively successful tactic of imperialist intervention and is an orientalist practice. As Anderson (2016) states: "so long as the big power is not seen to be directly involved, western audiences find quite attractive the idea that they might be helping another people rise up and gain their 'freedom"' ( $p$. 112). The creation of the idea of the War in Syria as a "civil war" supports the justification for the intervention of the west in the War in Syria. Following this expansion of three concepts; the creation of ISIL/ISIS, the supposed "brutality" of President Bashar al Assad, and the idea of the War in Syria as a so-called "Civil War", I will now begin to the conclusion of this thesis. 


\section{Chapter: Conclusions, Limitations and Suggestions for Future Research}

This thesis focuses on the photograph of the Syrian refugee, Aylan Kurdi taken after his drowning off the coast of Bodrum, Turkey. This photograph was widely internationally circulated in the first week of September 2015 following Aylan's death on September $2^{\text {nd }} 2015$. In this thesis I make the original claim that Aylan's photograph has come to be a focal point for the western understanding of the War in Syria. The Canadian news media, through newspaper articles released after Aylan's death, told particular stories about Syrian refugees, Syria and the East as a whole and presented narratives about Canadians, Canada and the west as a whole. Arguably, this was done through discussions of refugee departure from their countries of origin or refugee arrival in their destination countries. Aylan's body exists at the literal line in the sand between arrival in his destination country of Turkey and departure from his country of origin, Syria, making Aylan's photograph a focal point for the western understanding of the War in Syria. My research into Canadian newspapers has examined how certain images of the Middle Eastern "other" are used to advance particular western imperialist social, political and economic response agendas which serve simultaneously to reinforce a racist and Orientalist understanding of the East.

Aylan's photograph simultaneously proves and confirms the apparently objectively true reality of the War in Syria and thus eliminates the opportunity for any opposing debate or discussion. As Sontag states: "photography implies that we know about the world if we accept it as the camera records it. But this is the opposite of understanding, which starts from not accepting the world as it looks" (1977, p.23). Thus although the Canadian news media drew many truths from Aylan's photograph, these served primarily to confirm and reinforce particular western imperialist and Orientalist understandings of Syrian refugees and the War in Syria and 
eliminated the ability or option of contesting and challenging those assumptions. The hegemonic and imperialist nature of western knowledge of the Orient, in particular the Middle East, often overrides "the possibility that a more independent or more skeptical, thinker might have had different views on the matter" (Said, 1978, p. 7). Aylan's image was read in much the same wasy throughout all but one of the articles that I examined. Imperialist claims about the War in Syria were made as though they were indisputable facts, and virtually no contradictory sentiments were expressed. It is evident that throughout my thesis particularily in Chapter 2 and Chapter 5 that I have leaned heavily on journalists, writers and academics that champion some of these contradictory readings, to attempt to redress some balance.

The first half the data upon which this thesis rests is a collection of three iterations of the photograph of Alan Kurdi, taken by the Turkish photographer Nilufer Demir. I drew on the work of Sontag, Hariman and Lucaites to conduct photographic image analysis. The second half the data upon which this thesis rests is a collection of 168 newspaper articles that appeared in The Globe and Mail, the Toronto Star, the National Post, The Vancouver Sun, The Spectator, The Province, the Calgary Herald, the Winnipeg Free Press, the Ottawa Citizen, The Edmonton Journal, The Chronicle-Herald and The Gazette. These are some of the top Canadian newspapers by circulation that have both an online and print format. The articles chosen were newspaper articles that included the search term "Aylan Kurdi" and were published and released within 7 days of Aylan Kurdi's death on September $2^{\text {nd }}$ 2015. I performed qualitative discourse analysis on these articles relying on the work of Fairclough, Callaghan and Schnell.

Through the image analysis portion of this thesis I discovered that Nilufer Demir's images of Aylan were overwhelmingly intended to produce an empathetic response in the viewer. This was accomplished through the use of various photographic and visual techniques 
that are commonly employed in iconic news photographs. This result was in line with my expectation. Having seen the photograph before the commencement of this thesis, I was well aware of the emotional impact of the image. Through the discourse analysis portion of my thesis I was surprised by my results. While I expected to find articles that cautioned against onedimensional imperialist interpretations of Aylan's death, to find a dialogue between two opposing interpretations of Aylan's death or at the very least a mention of the possibility that the particular interpretation under examination was erroneous, I found nothing of the sort. Instead I found articles loudly decrying the War in Syria, the "plight" of Syrian refugees that was of their country's own making and the heaping of blame upon all but the west and their allies. Baseless predictions were made about the consequences of the arrival of Syrian refuges in Canada and the horrifying brutality causing the departure of Syrian refugees from Syria. A summary of my discourse analysis results and some notable findings are displayed in the table below:

\begin{tabular}{|c|c|}
\hline \multicolumn{2}{|r|}{ Table 1: Summary of Results and Notable Findings } \\
\hline \multicolumn{2}{|r|}{ Part 1: Arrival of Syrian Refugees in Canada } \\
\hline $\begin{array}{l}\text { Part 1a: } \\
\text { Broken } \\
\text { Refugee } \\
\text { Acceptance } \\
\text { Process }\end{array}$ & $\begin{array}{l}\text { 1. It is impossible to settle Syrian refugees in Canada, due to a lack of } \\
\text { social and institutional support. } \\
\text { 2. The bureaucratic refugee acceptance process itself makes the acceptance } \\
\text { of refugees almost impossible. } \\
\text { 3. The bureaucratic refugee acceptance process is responsible for the } \\
\text { deaths of Syrian refugees. }\end{array}$ \\
\hline $\begin{array}{l}\text { Part 1b: } \\
\text { Canada's } \\
\text { Good Image }\end{array}$ & $\begin{array}{l}\text { 1. Canada is morally obligated to accept Syrian refugees to sustain its } \\
\text { national character. } \\
\text { 2. Western countries are "progressive" and therefore must demonstrate } \\
\text { that through their generosity in accepting refugees. } \\
\text { 3. Canada must continue its much-lauded history of "exceptional" refugee } \\
\text { acceptance. }\end{array}$ \\
\hline $\begin{array}{l}\text { Part 1c: } \\
\text { Federal } \\
\text { Election Game }\end{array}$ & $\begin{array}{l}\text { 1. The then-current Conservative leadership's exclusionary immigration } \\
\text { policies are responsible for Aylan's death. } \\
\text { 2. The then-imminent } 2015 \text { Canadian Federal Election was an opportunity } \\
\text { to revisit immigration policies and make new leadership choices. }\end{array}$ \\
\hline $\begin{array}{l}\text { Part 1d: } \\
\text { Canada Can } \\
\text { Profit from } \\
\text { Refugees } \\
\end{array}$ & $\begin{array}{l}\text { 1. Syrian refugees in Canada are potential future economic assets to } \\
\text { Canada, which will allow for Canada to maintain a competitive } \\
\text { economy. }\end{array}$ \\
\hline
\end{tabular}




\begin{tabular}{|l|l|}
\hline $\begin{array}{l}\text { Part le: } \\
\text { Refugees are } \\
\text { Unwanted }\end{array}$ & $\begin{array}{l}\text { 1. The integrity of Canada's borders is paramount and that "bogus" or } \\
\text { "undeserving" refugees must be excluded. }\end{array}$ \\
\hline $\begin{array}{l}\text { Part 1f: } \\
\text { Canada is a } \\
\text { Safe Space }\end{array}$ & $\begin{array}{l}\text { 1. Canada is a desirable and bucolic "safe space" in which all non- } \\
\text { westerners aspire to live. }\end{array}$ \\
\hline \multicolumn{1}{|l|}{ Part 2: Departure of Syrian Refugees from Syria } \\
\hline $\begin{array}{l}\text { Part 2a: Brutal } \\
\text { Regime in } \\
\text { Syria }\end{array}$ & $\begin{array}{l}\text { 1. ISIL/ISIS is to blame for the conditions in Syria. } \\
\text { 2. Syrian President Bashar al Assad is to blame for the conditions in Syria. } \\
\text { 3. The so-called "Civil War" is to blame for the conditions in Syria. } \\
\text { (*Only one article took this stance.) }\end{array}$ \\
\hline
\end{tabular}

The photographic analysis and the information amalgamated in the above table is the bulk of my thesis' contribution to the prevailing literature on the framing of the War in Syria. Additionally, throughout the thesis, I have also attempted to collect and present alternative interpretations of the War in Syria from a variety of writers, journalists and academics. Their work, collected around the focal point that is Aylan's photograph, also contributes to the critical stance I have taken throughout this thesis and serves to uphold my commitment to an unflinching examination of the reality of the War in Syria.

In an examination of my research data and data collection methods, I have identified five major limitations. The first two limitations concern the discourse analysis data collection, the third limitation concerns the discourse analysis method itself and the fourth and fifth limitations concern the image analysis data collection. The first limitation of my discourse analysis article collection is that I chose only English Canadian newspaper articles (online and print). This course of action eliminated the potentially different French cultural perspective on the War in Syria and ignored the vast amount of writing about Aylan which was in the form of social media posts, journalistic blog posts, press releases, advertisements, government documents...etc. By cutting away this large swathe of discourse on Aylan and on the War in Syria, I potentially 
missed pieces of information that would have enhanced my evaluation of the discourse on the arrival of Syrian refugees in Canada and the departure of Syrian refugees from Syria.

The second limitation of my discourse analysis article collection is that I focused solely on Canadian sources. Although I chose to do this mainly in the interest of time constraints, my connection between the Canadian news media's interpretation of Aylan's photograph to how the rest of the west understands Aylan's photograph is tenuous. As mentioned previously, Aylan's photograph was shared instantaneously around the world across various social media platforms before filtering down into traditional news media sources. Without a discussion of how these varied international outlets depicted Aylan, Syrian refugees and the War in Syria, the work in this thesis could be construed as remarkably one-dimensional. Despite this, my integration of alternative and varied international sources throughout the thesis, somewhat compensates for omitting those other sources and supports my reading of the western perspective on the War in Syria.

The third limitation concerns the limitations of the research practice of CDA itself. Morgan (2010, p. 4) identifies three limitations of CDA that apply to the work I have done:

- As each tradition of CDA has its own epistemological position, concepts, procedures, and a particular understanding of discourse and discourse analysis each tradition is accompanied by certain critiques;

- Meaning is never fixed and everything is always open to interpretation and negotiation;

- The general lack of explicit techniques for researchers to follow has been indicated as a hindrance. (Note: I compensated for the lack of an explicit CDA technique by developing my own technique, using the work of Fairclough, Callaghan and Schnell. I argue that this method, described in detail in the above sections, is as rigorous and structured as any.) 
I will now attempt to address these limitations outlined by Morgan (2010) in turn.

As this thesis makes use of Fairclough's CDA modified somewhat by Callaghan and Schnell's frame analysis, I am confronted with some of the issues and critiques of Fairclough's methodology. Blommaert and Bulcaen (2000) examine some of the critiques of Fairclough's critical discourse analysis. Blommaert and Bulcaen (2000) note that the first central critique of Fairclough's discourse analysis is that there is a vagueness and shifting meaning between the terms employed by Fairclough to describe the process of CDA (Widdowson, 1985, 1996, 1998, as cited in, Blommaert \& Bulcaen, 2000). Although this may be accurate, my choice to combine and supplement Fairclough's method with the media frame analysis examples provided by Callaghan and Schnell (2001) enabled me to work through this confusion and to apply Fairclough's central objective of uncovering of "taken-for-granted" assumptions without undue complications.

Blommaert and Bulcaen (2000) also focus on Widdowson's argument that in its actual analyses, and despite its theoretical claims to the opposite, CDA interprets discourse under the guise of critical analysis. Since these interpretations may vary depending on how the text is read, or under what social circumstances the text is produced and consumed, the issues of interpretation and negotiation become central. Blommaert and Bulcaen (2000) question whether analysts and researchers can speak for the average consumer of texts, in other words, can I as a researcher be confident that I have correctly interpreted each article's meaning and presentation of Aylan, Syrian refugees and the War in Syria? Since CDA is a constant interpretation and negotiation between the researcher's internal knowledge, the discourse itself, and other related external knowledge, can I as a researcher be assured that I have rigorously and effectively 
examined each text? That I have not let my own feelings, political biases and prejudices be projected onto the data and then analyzed them instead of critically engaging with the texts themselves? While I have constantly attempted to refer back to the text itself, to draw meaning and intent from the words actually used, I believe this is an unavoidable limitation of the CDA methodology. This limitation may severely impact my results as it is possible that my own position as researcher might actively produce misrepresentations of information or sustain "shared modes of unknowing and forgetting central to the perpetuation of injustice" since my initial actions may have unconsciously eliminated data that did not already confirm what I believed (Hawkesworth, 2006, p. 140).

However, as a qualitative researcher I subscribe to Schwartz-Shea and Yanow's (2012) sentiment that notions of "researcher as contaminant" lead to inflexible research protocols that are designed to produce physical and cognitive-emotional distance from research participants and research data (p. 97). As Schwartz-Shea and Yanow (2012) argue, from an interpretive methodological perspective, like the one I employ in this thesis, these conceptualizations of researcher bias are problematic. It is naïve at best and dangerous at worst to assume that researchers can enter these field in a disembodied way, as if they could conduct their research in a detached and robotic manner. A researcher's embodied self constitutes "the primary instrument for accessing and making sense of these individual and community meaning-making processes" that uniquely brand and inform their research (Schwartz-Shea \&Yanow, 2012, p. 98). My interpretation and exploration of these texts necessarily and happily infuses my research with my self. While I remain unwavering in my commitment to rigorous and critical analysis, I must bring my own knowledge, skills as a researcher and my own intimate awareness of my subject to my project. 
The fourth and fifth limitations of my thesis concern the collection and analysis of the photographic data. The fourth limitation centers on the fact that I have included no discussion of the motivations or intent of the photographer Nilufer Demir. Throughout this thesis I have levelled harsh criticisms towards Turkey's manipulation of events and role in the violence in Syria. Demir's Turkish origin and media role could quite possibly play an important role in her motivations for taking and releasing the photographs of Aylan. The compassion she is able to elicit in the viewer may supplement the Turkish stance on the War in Syria. Without speaking to her directly, I cannot confirm her intentions or motivations. However, as Sontag states: "a photograph that brings news of some unsuspected zone of misery cannot make a dent in public opinion unless there is an appropriate context of feeling and attitude" (1977, p. 17). The ability of the photograph of Aylan to build nascent moral positions is unquestioned and Demir's choice to photograph and exhibit Aylan, which she has said was "the only thing to do", thus also unquestioningly reinforces a particular moral position and likely also supports a particular stance on the War in Syria (Griggs, 2015, p.1). The lack of a deeper examination of Demir's photographic motivations and intent is a limitation of this thesis. Developing a greater understanding of the motivations and intent of photographers, who photograph human misery and pain in all its forms, would be an interesting avenue for future research.

The fifth and final limitation of this thesis was the absence of a discussion on other visual and artistic responses to Aylan's photograph. Due the photograph's instantaneous and widespread dissemination, many professional and amateur artists were inspired and responded by producing various pieces of art. For example Chinese artist Ai Weiwei re-created the photograph of Aylan Kurdi and posed for a photograph on a beach on the Greek island of Lesbos, as seen in Figure 9. According to the Washington Post the image of Weiwei on the 
beach was staged by Weiwei and his team as part of an exhibition at the India Art Fair (Lakshmi, 2016, p. 1). Weiwei's photograph has been called both powerful (Lakshmi, 2016) and tasteless (Steadman, 2016). Brooklyn artist Sean Capone went so far as to state that the photograph exemplified Weiwei's "bad taste, egotistical victim porn and endless parade of crappy art" (Steadman, 2016, p. 1). Despite the difference in the critical reception of the piece, in a sense, it (and other pieces like it) serve to enrich the "discourse" produced on the War in Syria and this thesis would have benefitted from an examination of them. In addition to addressing some of the research limitations discussed above, an exploration of these artistic responses and thorough analysis of their content and context would be an excellent place for further research.

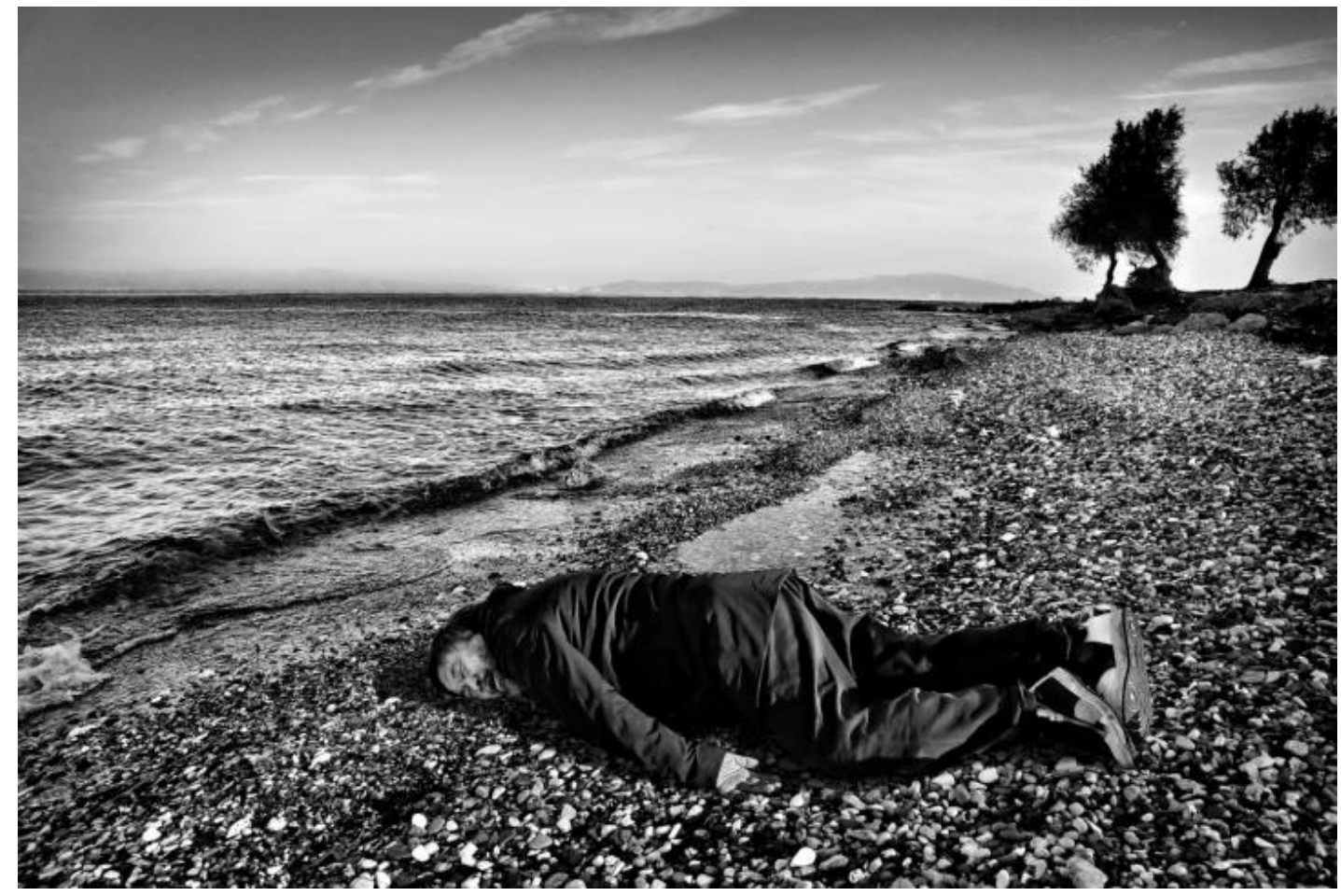

Figure 9: Photograph of Chinese artist Ai Weiwei on the Greek Island of Lesbos taken by Rohit Chawla (Lakshmi, 2016).

Throughout this thesis I have attempted to examine how Aylan Kurdi's photograph comes to stand for the reality of his body and life and for the reality of refugees in Syria. Aylan's 
photographed body is seen as objective proof of the violence and horror in Syria which substantiates claims made by the Canadian news media about the departure conditions refugees fleeing the War in Syria. Aylan's body, once photographed has come to be both a "token of [Aylan's] absence" and also a "pseudo-presence" of Aylan that is representative of refugees (Sontag, 1977, p. 16). Any other information regarding the departure of refugees from Syria is scrutinized and examined in comparison to that interpretation, which makes the work I have done to judiciously present and champion alternative interpretations of the War in Syria a foundational and crucial aspect of this thesis. Aylan's photographed body is also seen as objective proof of the failure of the implemented solutions to the reality of refugees and the War in Syria, which substantiates claims made by the Canadian news media about the arrival of refugees in Canada. Canadian news media claims about both Syrian refugee departure and arrival are symptomatic of a white western ventriloquism (Hawkesworth, 2006) that attempts to center white western interests and agendas that "other" refugees in a viscous process of orientalist western imperialism (Said, 1978). 


\section{References}

Abdo, N. (2014). Captive Revolution. London: Pluto Press.

Abley, M. (2015, September 5). Refugee, migrant or Alien? The words have very different connotations. Montreal Gazette, pp. B6.

Abu-Lughod, L. (2002). Do Muslim Women Really Need Saving? Anthropological Reflections on Cultural Relativism and Its Others. American Anthropologist, 104(3), 783-790. Retrieved from http://www.jstor.org/stable/3567256

Abu-Lughod, L. (2006). Local Contexts of Islamism In Popular Media. In D. Douwes (Ed.),ISIM Papers, (5-20). Amsterdam: Amsterdam University Press.

Adams, J. (2015, September 5). The decisive moment; seeing a picture of Alan Kurdi facedown on the beach sparked outrage in a way mere words never could. Globe and Mail, pp. F3.

Ahmed, A. (2016, March 18). Dear Laura Bush, This Is Not The Way To Help Oppressed Women. The Huffington Post. Retrieved from: http://www.huffingtonpost.com/entry/laura-bushafghanistan-women_us_56e88180e4b0860f99dad871

Al-Jazeera Media Network. (2014). Islamic State has 50,000 fighters in Syria. Al-Jazeera. Retrieved from http:/www.aljazeera.com/news/middleeast/2014/08/islamic-state-50000fighters-syria-2014819184258421392.html

Al-Jazeera Media Network. (2016). UNHCR: 2,500 refugees drowned on way to Europe in 2016. Al-Jazeera. Retrieved from http://www.aljazeera.com/news/2016/05/unhcr-2500refugees-drowned-europe-2016-160531104504090.html 
Aji, A. (2014, June 4). Bashar Assad claims landslide election win in Syria. CTV. Retrieved from http://www.ctvnews.ca/world/bashar-assad-claims-landslide-election-win-in-syria1.1852856

An unfair outcome. (2015, September 4). Edmonton Journal, pp. A22.

Anderson, T. (2016). The Dirty War on Syria: Washington Regime Change and Resistance. Montreal: Global Research E-Book Series.

Anderson, T. (2016, March 27). Washington and the 'Islamic State' (ISIS): The Evidence. Retrieved from http://www.tim-anderson.info/washington-and-the-islamic-state-isis-theevidence/

Anderson, T. (2014, September 30). Why Syrians support Bashar al Assad. In Gaza. Retrieved from https://ingaza.wordpress.com/2014/09/30/tim-anderson-why-syrians-supportbashar-al-assad/

Anonymous. (2015, September 4). A boy speaks for millions. Winnipeg Free Press, pp. A1. Anonymous. (2015, September 8). Tory trail littered with potholes. Winnipeg Free Press, pp. A8.

Azoulay, A. (2008). The Civil Contract of Photography. New York: Zone Books.

Barthes, R. (1977). Image-Music-Text. (S. Heath, Trans.). New York: Hill and Wang.

Bartlett, E. (2016). Eva Bartlett on Syria: Responding to Buzzfeed. OffGuardian. Retrieved from https://off-guardian.org/2016/12/16/eva-bartlett-on-syria-responding-to-buzzfeed/.

Bartlett, E. (2014). Syrians Flock to Vote in Lebanon...But Not in the West. Inter Press Service News Agency. Retrieved from http:/www.ipsnews.net/2014/05/syrians-flock-votelebanon-west/. 
Bartlett, E. (2014). Useful Atrocities. Zero Anthropology. Retrieved from https://zeroanthropology.net/2014/10/26/useful-atrocities/

Bassam, L \& A. Osborn. (2015, October 2). Iran Troops to Join Syria War, Russia Bombs Group Trained by CIA. Reuters. Retrieved from http://www.reuters.com/article/us-mideastcrisis-russia-syria-idUSKCNORV41O20151002

Berthiaume, L. (2015, September 5). Conservative rule change blamed for refugee backlog; Part Of 2012 Overhaul. National Post, pp. A9.

Berthiaume, L. (2015, September 5). Gov't rule overhaul blamed for backlog; Change in refugee status requirements designed to reduce number of private sponsorships. Vancouver Sun, pp. B3.

Berthiaume, L. (2015, September 5). Rule change blamed for refugee backlog; Update expected to 'reduce G5 submission by 70\%', notes reveal. Montreal Gazette, pp. A8.

Berthiaume, L. (2015, September 5). Rule change blamed for Syrian refugee backlog. Ottawa Citizen, pp. A1.

Berthiaume, L. (2015, September 5). Rule overhaul blamed for refugee backlog: Change expected to reduce private sponsor submissions by 70 per cent. Edmonton Journal, pp. A15.

Berthiaume, L. (2015, September 5). Tory rule changes blamed for refugee backlog. The LeaderPost, pp. A9.

Berton, P. (2015, September 5). Can a photo change the world?; Anger, disgust, shock: reactions vary over image of dead child. Hamilton Spectator, pp. A2.

Beuthin, R. (2014). Breathing in the Mud: Tensions in Narrative Interviewing. International Journal of Qualitative Methods.13. 122-134. 
Black, D. (2015, September 4). GTA residents rally behind refugees; 'We can't keep up with the calls,' says Lifeline Syria spokeswoman. Toronto Star, pp. A7.

Blackwell, T. (2015, September 4). Heart-rending story could tighten race in minister's riding; key contest. National Post, pp. A6.

Blackwell, T. (2015, September 4). Heart-rending story could tighten race; Alexander's Riding. National Post, pp. A6.

Blanchfield, M. (2015, September 4). Young migrant's image jolts leaders in mid-campaign. Hamilton Spectator, pp. A11.

Blatchford, C. (2015, September 4). Don't blame harper for the tragedy. Calgary Herald, pp. A14.

Blatchford, C. (2015, September 4). Don't blame Harper for the tragedy; Middle East: If the deaths of two young boys should make us mad, it should be because of the war. Vancouver Sun, pp. B3.

Blatchford, C. (2015, September 4). Don't blame harper for this tragedy; with the Syrian refugee crisis, there's a very long list of people to be mad at. Ottawa Citizen, pp. A6.

Blatchford, C. (2015, September 4). Don't blame harper for this tragedy. National Post, pp. A1 Blatchford, C., \& Gazette, T. (2015, September 4). Don't blame harper for the tragedy; refugee policy alone will not undo this crisis. Montreal Gazette, pp. A13.

Blatchford, C., \& Post, N. (2015, September 4). Don't blame harper for the tragedy; reasoned response calls for supporting efforts to end the war that caused it. Edmonton Journal, pp. A18.

Blommaert, J. \& C. Bulcaen. (2000). Critical Discourse Analysis. Annual Review of Anthropology. 29, p. 447-466. 
Blum, W. (2004). Freeing the World to Death. New York: Common Courage Press.

Blumenthal, M. (2016). How the White Helmets Became International Heroes While Pushing U.S. Military Intervention and Regime Change in Syria. Alternet: Grayzone Project. Retrieved from http://www.alternet.org/grayzone-project/how-white-helmets-becameinternational-heroes-while-pushing-us-military.

Boesveld, S. (2015, September 5). Countrywide pressure on Harper for quick action. Edmonton Journal, pp. A17.

Boesveld, S. (2015, September 5). Harper facing mounting pressure to take action on refugees. Vancouver Sun, pp. B5.

Boesveld, S. (2015, September 5). Harper facing pressure to take immediate action; Four provinces pledge monetary aid to help refugees fleeing Syria. Calgary Herald, pp. A18.

Boesveld, S. (2015, September 5). Harper pressed to act on refugees; Group that once opposed helping boat people calls for bigger effort. Montreal Gazette, pp. A14.

Boesveld, S. (2015, September 5). PM under pressure to take quick action; Toronto Mayor to help sponsor refugee family. National Post, pp. A8.

Bramham, D. (2015, September 4). Compassionate Canada has lost its way; Too little done: We no longer are who we think we are. Vancouver Sun, pp. A6.

Butler, D. (2015, September 5). Syrian refugee family settles into life in Ottawa; Fleeing war and persecution, the Al Dabeis have a new home here. Ottawa Citizen, pp. A2.

Callaghan, K. and Schnell, F. (2001). Assessing the Democratic Debate: How the News Media Frame Elite Policy Discourse. Political Communication, 18(1), 183-212.

Canada fails the challenge. (2015, September 4). Toronto Star, pp. A18.

Canada must take more Syrian refugees. (2015, September 5). Vancouver Sun, pp. B9. 
Casey, L., \& Omand, G. (2015, September 5). Refugee crisis; kurdi tragedy: Loss, confusion; mom, boys died in bid to reach europe; B.C. relative mourns. Chronicle-Herald, pp. A11.

CBC Media Group. (2001). Underground Railroad. Retrieved from http://www.cbc.ca/history/EPCONTENTSE1EP8CH1PA3LE.html.

Charbonneau, L. (2016). Syria Government, ISIS Commit Crimes Against Humanity: U.N.Backed Inquiry. Reuters. Retrieved from http://www.reuters.com/article/us-mideastcrisis-syria-un-idUSKCN0VV1QS

Cheadle, B. (2015, September 5). Leaders disagree on role of military; Election campaign sideswiped by refugee crisis. Hamilton Spectator, pp. A10.

Cheadle, B. (2015, September 5). Migrant crisis dominates debate on election trail; Plight of refugees draws attention from management of economy. Calgary Herald, pp. A16.

Cheadle, B. (2015, September 5). Migrant crisis dominates debate; Leaders spar over military role in conflict. Edmonton Journal, pp. A15.

Cheadle, B. (2015, September 5). Sparring over Canada's air war in Syria. Ottawa Citizen, pp. A4.

Cheadle, B. (2015, September 5). Sparring resumes over Canada's air war in Syria, Iraq; Refugee Debate. National Post, pp. A7.

Cheadle, B. (2015, September 5). Syria crisis dominates campaign; Partisan lines drawn as leaders clash over response to migrant issue. Vancouver Sun, pp. B3.

Cockburn, P. (2014). Isis Consolidates. London Review of Books, 36(16), 3-5. Retrieved from http://www.lrb.co.uk/v36/n16/patrick-cockburn/isis-consolidates. 
Cockburn, P. (2015). Too Weak, Too Strong. London Review of Books, 37(21), 3-6. Retrieved from http://www.lrb.co.uk/v37/n21/patrick-cockburn/too-weak-too-strong.

Cooke, M. (2002). Saving Brown Women. Signs, 28(1), 468-470. doi:1. Retrieved from http://www.jstor.org/stable/10.1086/340888 doi:1

Coyne, A. (2015, September 5). It is past time we act on Syria. National Post, pp. A8.

Coyne, A. (2015, September 5). What happens next?; Syria: We must not waste the collective surge of goodwill set off in the wake of the photo that gave an identity to the refugee crisis. Vancouver Sun, pp. B9.

Coyne, A. (2015, September 5). What matters is that we act: Instead of trying to score points, leaders must unite on Syrian refugee crisis. Calgary Herald, pp. A25.

Coyne, A. (2015, September 5). What matters now is what we do next. Edmonton Journal, pp. A21.

Coyne, A. (2015, September 5). What really matters is what we do next; Collective surge of goodwill in wake of child's death must be channeled well. Montreal Gazette, pp. B7.

Coyne, A. (2015, September 5). What really matters is what we do next; Our national leaders have to step up when it comes to the refugee crisis. Ottawa Citizen, pp. B7.

Crane, S. A. (2008) Choosing Not to Look: Representation, Repatriation and Holocaust Atrocity Photography. History and Theory, 47, 309-330.

Crawford, T. (2015, September 8). Family of drowned Syrians say goodbye; Deaths that 'woke up the world' mourned at Simon Fraser University campus. Vancouver Sun, pp. A5.

Crawford, T. (2015, September 8). Family of drowned Syrians says farewell. Calgary Herald, pp. A8. 
Cukier, W. (2015, September 4). What will it take before we act?; Individuals can make a crucial difference for millions of Syrian refugees seeking safe haven. Toronto Star, pp. A19.

Cummings, M. (2015, September 5). Edmonton's Syrians moved by Kurdi photo; Child's death hits, motivates community. Edmonton Journal, pp. A6.

Curry, B. (2015, September 5). Federal Election 2015; Mulcair and Harper at odds over what is Canada's best Mideast strategy. Globe and Mail, pp. A6.

Curry, I. (2015, September 5). Federal election 2015; Mulcair and Harper at odds over what is Canada's best mideast strategy. Globe and Mail, pp. A6.

Curry, I. (2015, September 7). Refugees; Immigration Minister pressed for more action. Globe and Mail, pp. A3.

Delacourt, S. (2015, September 5). On this issue, voters can be more than spectators. Toronto Star, pp. IN2.

Denton, T. (2015, September 8). Canada's keep-them-out immigration policy. Winnipeg Free Press, pp. A13.

Dhillon, S. (2015, September 7). Sponsorship process deemed 'ridiculous'. Globe and Mail, pp. S1.

DiManno, R. (2015, September 4). Time for Canadians to look in the mirror. Toronto Star, pp. A2.

Don't let the moment pass. (2015, September 5). Toronto Star, pp. IN6.

Dyck, D. (2015, September 8). Syrian refugee crisis; Trudeau wants leaders to meet about response. Chronicle - Herald, pp. A8. 
Eagland, N. (2015, September 6). 'Three angels that have passed on'; memorial held in vancouver for refugee mother and two sons who died fleeing Syria. The Province, pp. A6.

Elghaway, A. \& E. Farer. (2015, September 5). Refugee Policy; Forget labels when we witness such dire human need. Globe and Mail, pp. F2.

Ellis, R. (2014). U.N. Panel Details ISIS Abuses in Syria, Says They Amount to War Crimes. CNN News. Retrieved from http://www.cnn.com/2014/11/14/world/meast/isiswar-crimes.

Estrin, M. \& J. Shapiro. (2014, February 4). The Proxy War Problem in Syria. Foreign Policy. Retrieved from http://foreignpolicy.com/2014/02/04/the-proxy-war-problem-in-syria/

European Union to redistribute migrants. (2015, September 8). National Post, pp. A6.

Export.Gov (2015). Dual Use Export Licenses.US Export Agency. Retrieved from http://www.export.gov/regulation/eg_main_018229.asp

Fairclough, N. (1995). Critical and Descriptive Goals in Discourse Analysis. In N. Fairclough (Ed.), Critical Discourse Analysis: The Critical Study of Language (27-53). New York: Longman.

Family's odyssey of hope ends in grief; Syrian family's search for a new life ends in drownings. (2015, September 4). Edmonton Journal, pp. A15.

Fekete, J. (2015, September 4). No asylum bid from Syrian boy's father: Ottawa; authorities were contacted at least twice by NDP MP about boys' family. Montreal Gazette, pp. A9.

Fekete, J. (2015, September 4). No refugee application from father of drowned Syrian boys: Government. Edmonton Journal, pp. A17. 
Fekete, J. (2015, September 4). No refugee applications from family: Minister; Authorities were contacted at least twice by NDP MP about boys' family. Calgary Herald, pp. A9.

Fekete, J. (2015, September 4). No request from dad, alexander says. Ottawa Citizen, pp. A1. Fekete, J. (2015, September 4). Officials didn't get refugee application from dad of drowned Syrian boys: minister. Vancouver Sun, pp. B2.

Fine, S. (2015, September 4). Bureaucratic hurdles litter once model sponsorship system. Globe and Mail, pp. A1.

Fisk, R. (2015, July 27). Turkey conflict: Every regional power has betrayed the Kurds so Turkish bombing is no surprise. Independent. Retrieved from http://www.independent.co.uk/voices/comment/turkey-conflict-every-regional-powerhas-betrayed-the-kurds-so-turkish-bombing-is-no-surprise-10420106.html

Fisk, R. (2015, October 4). Syria’s 'Moderates' Have Disappeared... And There Are no Good Guys. Independent. Retrieved from http:/www.independent.co.uk/voices/syria-smoderates-have-disappeared-and-there-are-no-good-guys-a6679406.html

Fisk, R. (2016, May 10). After Splitting with Al-Qaeda, Al-Nusra is Being Presented to The West as a Moderate Force. It's Nothing of The Sort. Independent. Retrieved from http://www.independent.co.uk/voices/after-splitting-with-al-qaeda-al-nusra-is-beingpresented-to-the-west-as-a-moderate-force-it-s-a 7022271.html

Flyvbjerg, B. (2001). Making Social Science Matter: Why Social Inquiry Fails And How it Can Succeed Again. Cambridge: Cambridge University Press.

Fraser, S., \& Katz, G. (2015, September 4). 'I blame the whole world' for deaths; B.C. woman rejected in bid to sponsor family mourns after tragedy off Turkish coast. ChronicleHerald, pp. A4. 
Friesen, J. \& J. Jones \& L. Perreaux. (2015, September 5). Municipal Response; Mayors from across the country vow to lead in settling refugees. Globe and Mail, pp. A13.

Gettelman, E. \& Slezic, L. (2007). Hidden Half: Women in Afghanistan. Mother Jones. Retrieved from http://www.motherjones.com/politics/2007/06/hidden-half-womenafghanistan-lana-slezic

Giroux, H. A. (2011, July-October). "Instants of truth": the "Kill Team" photos and the depravity of aesthetics. Afterimage. Retrieved from https://proxy.library.carleton.ca/login?url=http://go.galegroup.com.proxy.library.carleton. $\mathrm{ca} / \mathrm{ps} / \mathrm{i} . \mathrm{do} ? \mathrm{id}=\mathrm{GALE} \%$ 7CA266457036\&sid=summon\&v=2.1\&u=ocul_carleton\&it=r\&p= AONE\&sw $=$ w\&asid $=8 b 3938 \mathrm{cb} 72 \mathrm{~b} 934 \mathrm{cb} 556174168605 \mathrm{aa} 27$

Giraldi, P. (2011, December 19). NATO vs. Syria. The American Conservative. Retrieved from http://www.theamericanconservative.com/articles/nato-vs-syria/

Glavin, T. (2015, September 4). Family never had a chance. National Post, p. A2.

Glavin, T. (2015, September 4). Make young Alan's death matter; don't make it political. Vancouver Sun, pp. B1.

Glavin, T. (2015, September 4). The one photograph that really mattered; alan kurdi brought the world's attention to the Syrian crisis. Ottawa Citizen, pp. C5.

Glavin, T. (2015, September 4). Time to rise above politics and solve this; heartbreaking picture of a dead child raises difficult questions. Edmonton Journal, pp. A16.

Glavin, T. (2015, September 4). We need to rise above ourselves. Calgary Herald, pp. A13.

Glavin, T. (2015, September 4). We need to rise above ourselves. Montreal Gazette, pp. A11.

Goffman, E. (1974). Frame Analysis: An Essay on The Organization of Experience. Boston: Northeastern University Press. 
Gormley, S. (2015, September 4). Desperation overcomes fear of danger; migrants know they could drown, but have little choice. Edmonton Journal, pp. A17.

Gormley, S. (2015, September 4). It's 'a shame of humanity'; Syrians reflect on death of boys, unwillingness of West to help them. Vancouver Sun, pp. B2.

Gormley, S. (2015, September 4). Syrians wait for their turn to risk death; carry photo of boy. National Post, pp. A4.

Gormley, S. (2015, September 4). What does boy's death say about Canada, Syrians are wondering. Ottawa Citizen, pp. C5.

Griggs, B. (2015, September 3). Photographer describes 'scream' of migrant boy's 'silent body'. CNN. Retrieved from http://edition.cnn.com/2015/09/03/world/dead-migrant-boy-beachphotographer-nilufer-demir/index.html?eref=rss_europe

Guillemin, M. \& Gillam, L. (2004). Ethics, Reflexivity, and "Ethically Important Moments" in Research. Qualitative Inquiry. 10(2). 261-280.

Hampson, S. (2015, September 7). Philanthropy: With their home country in turmoil, Syrian family compelled to give back. Globe and Mail, pp. A3.

Hancock, A. M. (2004). The Politics of Disgust. New York: New York University Press.

Hariman, R. \& Lucaites, J. L. (2007). No Caption Needed: Iconic Photographs, Public Culture, and Liberal Democracy. Chicago: The University of Chicago Press.

Harper, T. (2015, September 4). Tragedy casts light on callous Tory policies. Toronto Star, pp. A1.

Harper, T. (2015, September 7). Dress rehearsal's over, cue the election lights. Toronto Star, pp. A4. 
Hawkesworth, M. E. (2006). Feminist Inquiry: From Political Conviction to Methodological Innovation. New Jersey: Rutgers University Press.

Hebert, C. (2015, September 5). Conservatives tone deaf to growing chorus. Toronto Star, pp. A16.

Henderson, P. (2015, September 8). NDP; Mulcair calls again for refugee action; but harper spurns efforts by new democrats, liberals for meeting on Syrians' plight. ChronicleHerald, pp. A11.

Henderson, P. (2015, September 8). Syrian crisis is in Harper's hands, Mulcair says; PM not interested in meeting party leaders for talks. Hamilton Spectator, pp. A12.

Hersh, S. M. (2007). The Redirection. The New Yorker. Retrieved from: www.newyorker.com/magazine-/2007/03/05/the-redirection

Hersh, S. M. (2013). Seymour Hersh on the Arab Spring. Democracy Now! Retrieved from http://www.democracynow.org/2011/6/3/seymour_hersh_on_the_arab_spring

Hersh, S. M. (2013). Whose Sarin? London Review of Books, 35(24), 9-12. Retrieved from http://www.lrb.co.uk/v35/n24/seymour-m-hersh/whose-sarin.

Hersh, S. M. (2014). The Red Line and the Rat Line. London Review of Books, 36(8), 21-24. Retrieved from http://www.lrb.co.uk/v36/n08/seymour-m-hersh/the-red-line-and-the-ratline.

Hersh, S. M. (2016). The Killing of Osama Bin Laden. London: Verso Books.

Hironaka, A. (2005). Neverending Wars: The International Community, Weak States, and the Perpetuation of Civil War. Cambridge: Harvard University Press.

Hobbes, T. (1651). Leviathan. London: Green Dragon. 
Hong, J. (2015, September 8). Turkish policeman describes profound sorrow of finding 3-yearold's body. Toronto Star, pp. A3.

Hopper, T. (2015, September 4). A family chased by war to sea. National Post, pp. A1.

Hopper, T. (2015, September 4). Washed up on a Turkish beach, The sad odyssey of a Syrian family whose search for a new life ended in drownings. Vancouver Sun, pp. B1.

Hopper, T. (2015, September 4). Washed up on a Turkish beach; sad odyssey of a Syrian family whose search for a new life ended in drownings. Calgary Herald, pp. A11.

Hopper, T. (2015, September 4). Washed up on a Turkish beach; sad odyssey of a Syrian family whose search for a new life ended in drownings. Montreal Gazette, pp. A8.

Hopper, T. (2015, September 8). 16 hours alone and adrift in the Aegean; Faced by a tide of 120,000 migrants in Greece, Italy and Hungary, the EU is drawing up plans to redistribute the newcomers across its 28 member states. Calgary Herald, pp. B1.

Hopper, T. (2015, September 8). EU drawing up plans to redistribute migrants. Edmonton Journal, pp. A14.

Howlett, K. (2015, September 4). Sponsorship; Toronto man anxious to help Syrians; lawyer awaits approval of his application to help displaced people, highlighting concerns canada's response to crisis is too slow. Globe and Mail, pp. A5.

Hui, A. (2015, September 5). Refugee process; One Syrian family's happy ending; Man tells of terror in his native country - and the immense joy in being accepted by Canada. Globe and Mail, pp. A14.

If Canada cares about refugees, let's show it. (2015, September 4). Vancouver Sun, pp. B6.

Iitson, J. \& C. Clark. (2015, September 4). Analysis; immigration minister 'flat-footed' on crisis; Canada's inadequate response to the worst refugee emergency since the second world 
war fall on a rising star within the conservative party, who is now seen as lacking the ‘iron grip' of his predecessor. Globe and Mail, pp. A3.

Ivision, J. (2015, September 4). Canadians expect PM to act now. National Post, pp. A4.

Jabir, H. (2015, September 7). Will the Alan Kurdi photo actually change anything. Toronto Star, pp. A11.

Jorgensen, M. \& Phillips, L. (2002). Laclau and Mouffe's Discourse Theory. In M. Jorgensen, \& L. Phillips (Eds.), Discourse Analysis as Theory and Method (24-59). London: SAGE Publications.

Keating, J. (2015, September 4). How to help the refugees; and why we won't do it. National Post, pp. A11.

Keating, J. (2015, September 4). How to help the refugees; and why we won't do it. National Post, pp. A11.

Keenan, E. (2015, September 4). What kind of country do we want to be? Toronto Star, pp. A4.

Kelly, A. (2016, September 26). West still arming Al-Nusra in Syria, peace almost impossible Russia's UN envoy. Reuters. Retrieved from https://www.rt.com/news/360571-unscsyria-meeting-russia/

Kennedy, M. (2015, September 4). Harper defends handling of crisis; conservative leader acknowledges photo of young boy 'heartbreaking'. Calgary Herald, pp. A15.

Kennedy, M. (2015, September 4). Harper defends his syria policy; world, canada have failed, Mulcair says. Edmonton Journal, pp. A16.

Kennedy, M. (2015, September 4). Harper defends Syria stance after Kurdi tragedy; Rivals Mulcair, Trudeau promise to do a better job taking care of refugees. Ottawa Citizen, pp. A3. 
Kennedy, M. (2015, September 4). Harper defends Syria stance after seeing tragic image. Montreal Gazette, pp. A13.

Kennedy, M. (2015, September 4). Policy alone won’t save Syria: Harper. Regina Leader-Post, pp. C8.

Kennedy, M. (2015, September 4). Tory leader defends Syria stance after 'heartbreaking' image. Vancouver Sun, pp. B3.

Kilford, C. (2015, September 5). Why Syria's refugees are Canada's business; We are meddling there, and we have always welcomed those in need. Ottawa Citizen, pp. B6.

Kobayashi, A. (1983). Multiculturalism: Representing a Canadian Institution, in Duncan, James S; Duncan, Ley, (Eds.). Place/Culture/Representation, p. 205-206. New York: Routledge.

Kolhatkar, S. (2002). “Saving” Afghan Women. Retrieved from http://www.rawa.org/znet.htm.

Lakshmi, R. (2016). Chinese artist Ai Weiwei poses as a drowned Syrian refugee toddler. The Washington Post. Retrieved from https://www.washingtonpost.com/news/worldviews/wp/2016/01/30/chinese-artist-aiweiwei-poses-as-a-drowned-syrian-refugee-toddler/?utm_term=.656a1d95d694.

Lamey, A. (2015, September 5). Refugee policy, weakened by Tory changes; We must recommit to 'naming' and 'additionality' as bedrock principles. Ottawa Citizen, pp. B7.

Larmour, E. (2015, September 4). Why did the Citizen publish this image? Ottawa Citizen, pp. C4.

Let's show we care. (2015, September 4). Ottawa Citizen, pp. C4.

Losier, B. (2015, September 4). Halt campaigns and help the refugees. Calgary Herald, pp. A19. 
Lowrie, M. (2015). Canadian Leaders Call for Continued Military Action Against ISIS. Star News. Retrieved from https://www.thestar.com/news/canada/2015/11/14/canadianleaders-call-for-continued-military-action-against-isis.html

MacCharles, T. (2015, September 4). Boy's death ignites political firestorm; Trudeau, Mulcair critical of Conservatives' reluctance to accept more refugees. Toronto Star, pp. A3.

MacCharles, T. (2015, September 5). Plight of Syrians becomes central issue on federal campaign trail; Leaders present their views - and tear apart each other's - on how Canada should respond to international crisis. Toronto Star, pp. A1.

Mackey, E. (1999). The House of Difference. New York: Routledge.

MacKinnon, M. (2015, September 4). Folio: Migrant crisis; 'I was only hoping to provide a better life for my children'. Globe and Mail, pp. A6.

MacKinnon, M. (2015, September 5). Folio: Migrant crisis; Resolve, peril and hope. Globe and Mail, pp. A10.

MacKinnon, M. (2015, September 7). Seeking Asylum; In Kos, Greece: Small island of dreams buffeted by hostility. Globe and Mail, pp. A1.

MacLeod, I. (2015, September 4). What has Canada been doing to help?; The tragic death of three-year-old refugee Alan Kurdi and his family has thrown a sharp spotlight on the Syrian crisis and Canada's response to it. Lee Berthiaume and Ian MacLeod tell you what you need to know. Ottawa Citizen, pp. A4.

Madokoro, L. (2015, September 4). Humanitarion crises; the power of a picture, the Indochinese refugee problem didn't receive significant attention in Canada until the Hai Hong arrived in Malaysia in 1978. Globe and Mail, pp. A4. 
Mahmood, M. \& M. Chulov. (2013, June 4). Syrian War Widens Sunni-Shia Schism as Foreign Jihadis Join Fight for Shrines. The Guardian. Retrieved from https://wayback.archive.org/web/20130604221924/http://www.guardian.co.uk/world/201 3/jun/04/syria-islamic-sunni-shia-shrines-volunteers

Mallick, H. (2015, September 5). I'm ashamed we didn't let the Kurdi family in. Toronto Star, pp. A10.

Mason, G. (2015, September 5). Outrage; Atrocities in Syria: The whole world is watching - and doing nothing. Globe and Mail, pp. S1.

McCooey, P. (2015, September 5). Tragic photo spurs donations; Aid pouring in locally. Ottawa Citizen, pp. A8.

Memorial held in Vancouver for drowned Syrian boys. (2015, September 6). Toronto Star, pp. A7.

Mills, C. (1997). The Racial Contract. New York: Cornell University Press.

Mohanty, C. (2003). Feminism Without Borders: Decolonizing Theory and Practicing Solidarity. Durham: Duke University Press.

Morgan, A. (2010). Discourse analysis: An overview for the Neophyte Researcher. Journal of Health and Social Care Improvement. 1(1), 1-7.

Motroc, G. (2015, February 26). Iraqi army downs two UK planes carrying weapons for ISIL. Australian National Review. Retrieved from http://www.australiannationalreview.com/iraqi-army-downs-uk-planes-carryingweapons-isil/.

Murphy, R. (2015, September 5). The picture that touched our hearts. National Post, pp. A16. 
Neve, A. \& B. Vaugrante. (2015, September 4). Time for meaningful action on mounting Syrian refugee crisis; Urgency, gravity of crisis demands leadership. Ottawa Citizen, pp. C4.

Nicks, D. (2014, September 5). U.S. Forms Anti-ISIS Coalition at NATO Summit. Time. Retrieved from http://ime.com/3273185/isis-us-nato/

Omidvar, R. (2015, September 4). Refugee crisis; practical solutions flow from political will. Globe and Mail, pp. A12.

Orwell, G. (1992). 1984. New York: Penguin.

Ozog, E. (2015, September 8). Bombing our way to a Mideast solution; Canada must do 'more,' including military strikes, says Harper, Sept. 4. Toronto Star, pp. A14.

Pearson, J. (2015, September 5). Trudeau exploited young boy's death. Calgary Herald, pp. A24.

Picard, A. (2015, September 7). Health: Journeys can leave lasting psychological and physical effects; Asylum seekers risk their lives for a better future. Globe and Mail, pp. A5.

Pillow, W. (2005). Confession, catharthis, or cure? Rethinking the Uses of Reflexivity as Methodological Power in Qualitative Research. Qualitative Studies in Education. 16(2), 175-196.

Potter, M. (2015, September 5). There's more than one evil in Syria. Toronto Star, pp. A1. Radwanski, A. (2015, September 5). Federal Election 2015; Harper tried for a little heart. Globe and Mail, pp. A9.

Richter, G. (2014) Syrian National Coalition President: Assad, ISIS not fighting each other newsmax. Newsmax. Retrieved from http://www.newsmax.com/Newsmax-Tv/syriancoalition-assad-isis/2014/09/30/id/597645/ 
Rothman, N. (2014, September 16). Dempsey: I know of Arab allies who fund ISIS. YouTube. Retrieved from https://www.youtube.com/watch?v=nA39iVSo7XE

RT. (2017, February 13). West 'did nothing' to end war in Syria, says aunt of drowned Syrian boy. $R T$. Retrieved from https:/www.rt.com/news/377162-west-syria-drowned-boy/

RT. (2014, October 3). Anyone but US! Biden blames allies for ISIS rise. RT. Retrieved from https://www.youtube.com/watch?v=1118nLZNPSY

Usher, B. P. (2014, October 7). Joe Biden apologised over IS remarks, but was he right? BBC News. Retrieved from http://www.bbc.com/news/world-us-canada-29528482

Sachgau, O. \& A. Chowdhry. (2015, September 4). Donations; Canadians search for ways to assist refugees. Globe and Mail, pp. A5.

Said, E. W. (1978). Orientalism. New York: Random House.

Said, R. (2015, December 10). Kurdish-Arab Coalition Fighting Islamic State in Syria Creates Political Wing. Reuters. Retrieved from http://www.globalpost.com/article/6702811/2015/12/10/syria-kurd-arab-coalitioncreates- political-wing

Sanders, C. (2015, September 4). Call to aid Syrians as we did Vietnamese. Winnipeg Free Press, pp. A1.

Schwartz-Shea, P. \& Yanow, D. (2011). Interpretive Research Design: Concepts and Processes. New York: Routledge.

Selley, C. (2015, September 4). The migrants' journey from hell. National Post, pp. A11.

Sentilles, S. (2008). Just looking: theological language, ethics, and photographs of violence. Harvard Theological Review, 101(3-4), 522. Retrieved from 
https://proxy.library.carleton.ca/login?url=http://go.galegroup.com.proxy.library.carleton. $\mathrm{ca} / \mathrm{ps} / \mathrm{i} . \mathrm{do}$ ?id=GALE$\% 7 \mathrm{CA} 191856531 \& \mathrm{sid}=$ summon\&v$=2.1 \& \mathrm{u}=\mathrm{ocul}$ carleton\&it=r\&p= AONE\&sw=w\&asid=a2de390dc819db561164f03229a9f3f5

Sheridan, K. (2015, September 5). Settle conflict, says Syrian church head; Religious leader urges government to go after the terrorist groups. Montreal Gazette, pp. A16.

Showler, P. (2015, September 8). Canada falls short on Syrian refugees; Harper's statements are misleading, and we can do more. Ottawa Citizen, pp. C4.

Sieniuc, K. (2015, September 7). Policeman still carries painful burden of finding boy on beach. Globe and Mail, pp. A1.

Simpson, J. (2015, September 5). A calamity for many years, and many reasons, to come. Globe and Mail, pp. F2.

Skinner, C. (2016). California College Attacker Inspired by ISIS, Acted Alone: FBI. Reuters. Retrieved from http://www.reuters.com/article/us-california-stabbing-idUSKCN0WK031

Slater, J. (2015, September 4). Migrant crisis; hope derailed; Joanna slater in Hungary; elation t urns to frenzied despair as migrants suddenly realize they are on the road to nowhere. Globe and Mail, pp. A1.

Smith, C. D. (2015, September 4). Faced with the worst refugee crisis in recent history, the Conservatives have continued to close the door on asylum-seekers. Toronto Star, pp. A19.

Smyth, M. (2015, September 6). Politicians play number games as syrian refugee crisis deepens; opposition leaders quick to criticize, but offer no practical solutions to tragedy. The Province, pp. A6.

Sontag, S. (1977). On Photography. Toronto: McGraw-Hill Ryerson Limited. 
Southwick, R. (2015, September 4). Nenshi slams tories over syrian refugees; but conservatives say mayor's comments based on 'misinformation'. Calgary Herald, pp. A4.

Southwick, R. (2015, September 7). \$53,000 raised to aid Syrian refugees; Organizers hope cash will sponsor two families. Calgary Herald, pp. A6.

Spencer Davis, S. (2015, September 7). Spurred by migrant child's death, GTA residents rally to help. Toronto Star, pp. A3.

Spencer, C. (2015, September 8). Admit more Syrian refugees: poll. National Post, pp. A5.

Spencer, C. (2015, September 8). Canada needs to do more for Syrian refugees, poll says; research. The Province, pp. A9.

Spencer, C. (2015, September 8). Canadians ready to take in many refugees, poll finds. Gazette, pp. A14.

Spencer, C. (2015, September 8). Canadians ready to take in thousands more refugees. Ottawa Citizen, pp. A4.

Spencer, C. (2015, September 8). Canadians ready to take in thousands: poll; Refugee crisis. National Post, pp. A5.

Spencer, C. (2015, September 8). Canadians want to admit Syrian refugees: poll. Edmonton Journal, pp. A14.

Spencer, C. (2015, September 8). Help displaced Syrians: poll; Nearly half of Canadians want more action on Mideast refugee crisis. Calgary Herald, pp. A1.

Spurr, B. (2015, September 7). Trudeau seeks unity on Canada's response; Germany opens its borders and Liberal leader calls for all-party meeting as shock over photo of drowned Syrian toddler reverberates around the world. Toronto Star, pp. A1. 
Sputnik News. (2016, January 22). Record Number of Refugees Drown in Mediterranean in January 2016 - IOM. Sputnik News. Retrieved from https://sputniknews.com/world/201601221033555561-record-number-refugees-drownmideterranean-january-2016/

Sputnik News. (2016, October 29). 'Speculating on Human Lives': Actual Civilian Death Toll in Syrian War. Sputnik News. Retrieved from https://sputniknews.com/middleeast/201610291046872027-civilian-casualties-syria/.

Sputnik News. (2015, March 11). Mr. Soft Heart or Brutal Tyrant? Anti-Assad Narrative Falls Apart at Seams. Sputnik News. Retrieved from https://sputniknews.com/politics/201511031029549034-assad-high-public-support-syriaelections/

Sputnik News. (2015, December 10). Sick 'Aura of Romance' Behind Daesh's Successes Recruiting New Fighters. Sputnik News. Retrieved from https://sputniknews.com/military/201512101031550739-daesh-recruitment-successes/.

Sputnik News. (2015, July 24). Saudi Army Helicopters Dropped Barrel Bombs on Civilians Near Yemen Border. Sputnik News. Retrieved from https://sputniknews.com/military/201507241025016444/.

Stark, E. (2015, September 5). No more talking: protesters; Calgarians call on government to step up admission of Syrian refugees. Calgary Herald, pp. A3.

Starr, S. (2015, September 6). Visiting the beach where Alan was found: Star Exclusive. Toronto Star, pp. A1.

Steadman, R. (2016, February, 2). Ai Weiwei Receives Backlash for Mimicking Image of Drowned 3-Year-Old Refugee. Observer. Retrieved from 
http://observer.com/2016/02/photo-of-ai-weiwei-aping-drowned-refugee-toddler-drawspraise-ire/

Steele, J. (2012, January 17). Most Syrians back President Assad, but you'd never know from western media. The Guardian. Retrieved from https://www.theguardian.com/commentisfree/2012/jan/17/syrians-support-assad-westernpropaganda

Stein, B. (1981). The Refugee Experience: Defining the Parameters of a Field of Study. The International Migration Review. 15(1/2). p. 320-330.

Sutcliffe, M. (2015, September 5). Behold - but beware - the power of iconic photos. Even images that move the world can never tell the whole story. Ottawa Citizen, pp. B8.

Syrian refugee crisis; The world needs more Canada. (2015, September 5). Globe and Mail, pp. F9.

Syrian refugee crisis; why can't we meet our (modest) goals? (2015, September 4). Globe and Mail, pp. A10.

Tamer, V. (2015, September 7). Turkey; A day in Bodrum; between attempts at crossing the Aegean Sea, migrants go back into the Turkish township, sleeping in public parks or at bus stations. Globe and Mail, pp. A4.

The boy on the beach. (2015, September 4). Montreal Gazette, pp. A16.

The sad scene on the beach overshadowed all else. (2015, September 5). Globe and Mail, pp. F8.

Thobani, S. (2007). Exalted Subjects. Toronto: University of Toronto Press.

Tracy, S. (2013). Qualitative Research Methods. Chichester, West Sussex: Blackwell Publishing.

Tutton, M. (2015, September 5). Canada can use lessons of Vietnam in refugee crisis; Former Prime Minister Joe Clark offers advice on Syrian exodus. Ottawa Citizen, pp. A4. 
Van Praet, N. (2015, September 8). Immigration; Quebec to triple admissions target; Province says it is taking steps to admit 3,650 Syrian refugees in 2015, but needs help from the federal government. Globe and Mail, pp. A3.

Vinograd, C \& C. Omar. (2014). Syria, ISIS Have Been 'Ignoring' Each Other on Battlefield, Data Suggests. NBC News. Retrieved from http://www.nbcnews.com/storyline/isisterror/syria-isis-have-been-ignoring-each-other-battlefield-data-suggests-n264551

Waldman, L. \& L Sandrehashemi. (2015, September 6). Refugee policies are mean and incompetent. Toronto Star, pp. A1.

Walkom, T. (2015, September 5). Harper looks to recover from summer heat. Toronto Star, pp. A6.

We can do more. (2015, September 4). National Post, pp. A8.

Woelfel, D. (2015, September 4). We need to speak up for Syrian refugees. Ottawa Citizen, pp. C4.

Yogaretnam, S. (2015, September 8). Parties want Canadians to band together. Ottawa Citizen, pp. A4.

Younglai, R. \& Nelson, J. (2015, September 5). Aid; Until now, Syria a hard sell for donations. Globe and Mail, pp. A14.

Zelizer, B. (2001). Visual Culture and the Holocaust. New Brunswick: Rutgers University Press. 